\title{
Southwest Montana Wetland \\ Assessment: Developing a statewide assessment and monitoring strategy for Montana
}

Prepared for:

The U.S. Environmental Protection Agency

Prepared by:

Karen R. Newlon

Ecologist / Project Manager

Montana Natural Heritage Program a cooperative program of the

Montana State Library and the University of Montana

September 2012

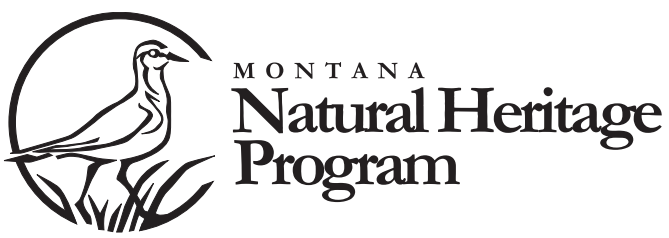





\section{Southwest Montana Wetland \\ Assessment: Developing a statewide assessment and monitoring strategy for Montana}

Prepared for:

The U.S. Environmental Protection Agency

Agreement Number:

CD-97847401

Prepared by:

Karen R. Newlon

Ecologist / Project Manager

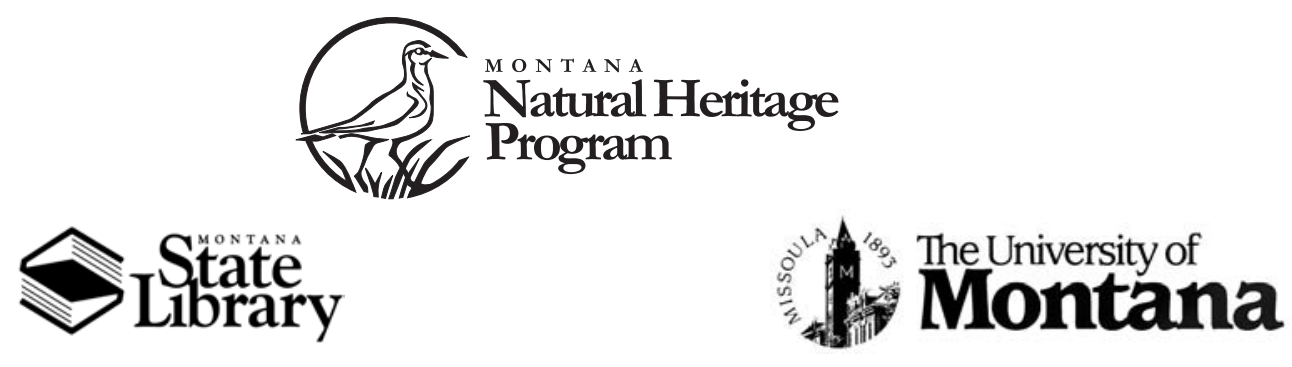

(c) 2012 Montana Natural Heritage Program

P.O. Box 201800 • 1515 East Sixth Avenue • Helena, MT 59620-1800 • 406-444-5354 
This document should be cited as follows:

Newlon, Karen R. 2012. Southwest Montana Wetland Assessment: Developing a statewide assessment and monitoring strategy for Montana. Report to the U.S. Environmental Protection Agency. Montana Natural Heritage Program, Helena, Montana. 39 pp. plus appendices. 


\section{Executive Summary}

Although wetlands are uncommon features across the landscape, they provide important functions and ecosystem services disproportionate to their abundance, particularly within semiarid portions of Montana and the Rocky Mountain West. Wetlands provide multiple biological and economic benefits such as plant and wildlife habitat, flood attenuation, groundwater recharge, and improvements to water quality. Despite these benefits, wetlands continue to experience pressures from multiple uses including urban, exurban, and agricultural development, as well as resource extraction. Quantifying the impact of these uses on wetland resources requires scientifically sound metrics to assess wetland condition. Recognizing the need for information on wetland condition at a watershed scale, the Montana Natural Heritage Program (MTNHP) initiated a statewide monitoring and assessment program in 2008 to report on the ambient condition of Montana's wetlands. These basin-wide assessments provide regionally specific information on the ecological integrity of wetlands.

This report summarizes the results of our second basin-wide assessment of wetlands in the Upper Missouri Headwaters of southwestern Montana. Our objective was to assess wetland condition within six watersheds at multiple spatial scales. We conducted Level 1 GIS analyses that produced: 1) wetland landscape profiles, which summarize information on wetland abundance, type, extent, and function within a given watershed; and 2) a landscape characterization, which characterizes the anthropogenic stressors such as roads and land uses, as well as general information regarding wetland landscape context, using readily available digital datasets. We conducted Level 2 assessments to provide rapid, field-based assessments of wetland condition. Finally, Level
3 intensive assessments provided detailed information on the structure and composition of wetland vegetation. This multi-tiered framework allows for the incorporation of multiple scales of assessment, integrating landscapelevel information, ambient wetland condition, and site-specific data.

We classified wetland types using the Ecological Systems classification, which provides a valuable means of classifying wetland systems based on both biotic and abiotic criteria to define landscape units. Additionally, this classification system captures the range of natural variability in wetlands while organizing them into manageable conceptual units.

We included all digitally mapped wetlands from National Wetlands Inventory (NWI) to produce wetland landscape profiles for the project area. For the Level 1 landscape characterization and Level 2 and Level 3 wetland assessments, the target population included all mapped palustrine wetlands greater than 0.1 ha. We followed a spatially balanced sampling approach to select wetlands for assessment.

For Level 1 values and Level 2 assessment scores, we calculated descriptive statistics and assessed the range and distribution of each metric by examining frequency histograms. For Level 3 assessments, we calculated multiple vegetation metrics to conduct a floristic quality assessment (FQA). The FQA accounts for the presence of both native and exotic species, as well as individual plant species' tolerance of and sensitivity to disturbance. We determined the relationship between our Level 3 vegetation metrics and our Level 2 assessment scores by examining Spearman's correlation coefficients. We also examined the relationship between our Level 3 metrics and stressors. 
Based on digital mapping, wetlands and other waterbodies within the project area total 228,992 ac (92,670 ha). Note that this total includes deepwater areas such as lakes and river channels, which provide critical aquatic habitat and other valuable ecosystem services but are not considered wetlands. The majority of mapped wetland acres were freshwater emergent wetlands (63\%).

We conducted a Level 1 landscape characterization on over 1,000 mapped palustrine wetland polygons and within $100-\mathrm{m}, 300-\mathrm{m}$, and 1,000-m envelopes around each polygon. The density of local roads (unpaved and rural roads) within selected wetland polygons was $2.1 \mathrm{~m} / \mathrm{h}$ but was four times higher when considered at the $100-\mathrm{m}$ envelope $(9.5 \mathrm{~m} / \mathrm{ha})$. Land uses within the project area were primarily agricultural. The proportion of lands irrigated and/or cultivated was greater with increasing spatial scales. For example, the percent of irrigated lands increased from $2.9 \%$ when considered at the wetland polygon scale to $8.4 \%$ in the 1,000-m envelope. The density of irrigation canals generally decreased with increasing spatial scales. On average, palustrine wetlands were $732 \mathrm{~m}$ from local roads, and $5.2 \mathrm{~km}$ and $2.1 \mathrm{~km}$ from hydrologic modifications such as canals and wells, respectively.

We visited 100 wetlands during the summer of 2010, conducting Level 2 assessments at 93 of these wetlands using the MTNHP Ecological Integrity Assessment (EIA) protocol. Wet meadow was the most common system sampled (40 sites). Emergent marsh was the second most sampled wetland system (29 sites). Other sampled systems included 16 riparian shrubland sites, seven fen sites, and one wooded vernal pool. Each wetland system had a unique suite of associated plant species.

Level 2 ecological integrity scores were calculated for all 93 wetlands sampled. Scores ranged from 55-100 out of a possible range of 21.5-100. We divided our assessment scores into four categories defined relative to their departure from reference standard. Wet meadows, emergent marshes, and riparian shrublands had scores across the range of condition categories, indicating they may be impacted by a range of stressors. Of the sampled wetlands, 38 wetlands were at or near reference standard, 29 wetlands were a slight departure from reference standard, 22 wetlands were a moderate departure from reference standard, and four sites were a severe departure from reference standard.

Most wetlands had some on-site stressors impacting the Landscape Context and the Vegetation attributes (57\% and $76 \%$ of sampled wetlands, respectively). Yet, few sites had stressors impacting the Physicochemical and Hydrologic attributes (6\% and $11 \%$ of sampled wetlands, respectively). A similar pattern was seen for stressors within the 200-m envelope. The majority of sampled wetlands had stressors impacting the Landscape Context and the Vegetation attributes ( $84 \%$ and $65 \%$ of sampled wetlands, respectively), whereas few wetlands had stressors impacting the Physicochemical and Hydrologic attributes $(9 \%$ and $8 \%$ of sampled wetlands, respectively).

We completed 29 Level 3 assessments within the project area, encountering 309 plant taxa. The average number of species encountered per site was 30 (range 9-49). Of the 272 species identified to species, $238(88 \%)$ were native species and 34 were exotic species.

We calculated floristic quality assessment (FQA) metrics for all 29 Level 3 assessment sites. Average mean C-value at these sites was 4.37. Fens had the highest mean C-value (4.94), and riparian shrublands had the lowest mean C-value (3.90). In general, values for metrics related to species richness were 
highest for riparian shrublands and lowest for emergent marshes, whereas fens had the highest values for metrics related to $\mathrm{C}$-values and floristic quality indices (FQIs).

To understand the effectiveness of this assessment framework in determining the condition of wetlands in the southwest Montana project area, we compared the results of each assessment level with the preceding level of assessment (e.g., Level 3 results compared with Level 2 results; Level 2 results compared with Level 1 results).

Landscape level (Level 1) ratings from a landscape integrity model (LIM) showed a moderate negative correlation between disturbance and Level 2 wetland condition scores $(r=-0.60)$.

Impact ratings within the 200-m envelope around the wetland assessment area (AA) and within the AA showed moderate negative correlations with overall Level 2 assessment scores ( $r=-0.71$ and $r=-0.61$, respectively). All Level 2 attribute scores showed moderate negative correlations with at least one impact rating category at either scale except the Vegetation attribute, indicating that our current stressor list may not adequately capture potential impacts to vegetation condition.

Of the 16 vegetation metrics evaluated in the FQA, only five metrics were correlated with stressors, overall wetland condition score, or both, and were not redundant with other vegetation metrics. These metrics were coverweighted mean C-value of all species, FQI for all species, cover-weighted FQI of all species, cover-weighted FQI of native species, and adjusted FQI.
When evaluating estimates of stressor extent, only three stressors showed a moderate negative correlation $(r \geq-0.5)$ with vegetation metrics. These included percent of the $200-\mathrm{m}$ envelope comprised of domestic/commercial development, percent grazed by livestock, and the length in meters of unpaved roads.

Results from this project indicate the wetlands sampled in southwest Montana are in relatively good condition. Wetlands had intact buffers, few hydrologic impacts, and low to moderate impacts to physicochemical properties. Scores were lowest for the Vegetation attribute across ecological systems. The component metrics within this attribute integrate the effects of multiple disturbances over multiple spatial scales. The other attributes focus either on the area around the AA (Landscape Context attributes) or immediate on-site impacts (Physicochemical and Hydrologic attributes), so these attributes reflect only certain aspects of overall wetland condition. Additionally, most vegetation metrics were not well correlated with stressor impacts, indicating that our current list of stressors is not adequately reflecting impacts on vegetation condition. Livestock grazing, recreation or human visitation, unpaved roads, and browsing by native ungulates were the most commonly encountered stressors. We will continue to explore additional approaches to account for anthropogenic impacts on plant species composition. 


\section{ACKNOWLeDgements}

This project was funded by an Environmental Protection Agency Region 8 Wetland Program Development Grant. I would like to thank Toney Ott and Jill Minter of EPA Region 8 for their support and commitment to wetland assessment and monitoring in our region. I thank Jessica Clarke, Nick Smith, and Sam Isham for spending long days in the field collecting data for this project. Sam Isham and Karissa Ramstead completed the field data entry for this project. Meghan Burns, Erika Colaiacomo, and Robin Lium completed digital wetland mapping integral to the completion of this project. Meghan Burns also conducted the GIS analyses necessary to complete the wetland landscape profile and Level 1 landscape characterization. Joanna Lemly of the Colorado Natural Heritage Program and Catherine McIntyre, formerly of MTNHP, provided helpful suggestions for data analyses and interpretation. Linda Vance of MTNHP provided useful and insightful comments on an earlier draft of this report. Coburn Currier of MTNHP formatted and edited the final version of this report. Any errors or omissions in the report are entirely the responsibility of the author. 


\section{Table of Contents}

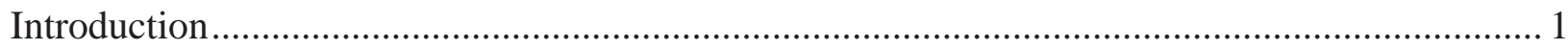

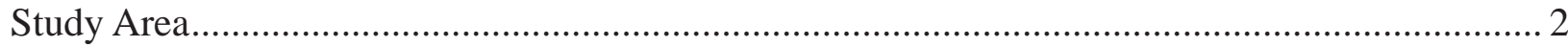

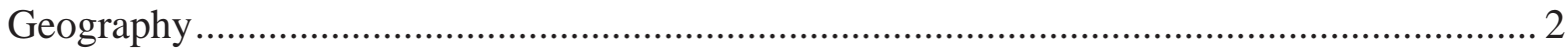

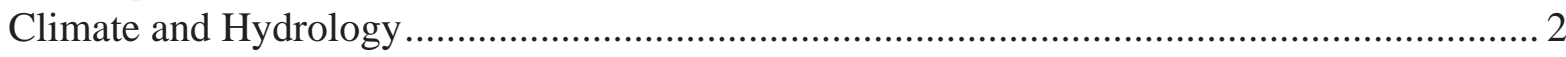

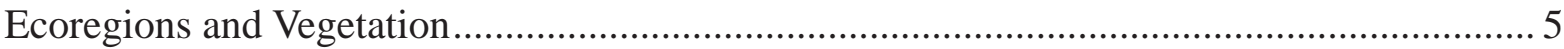

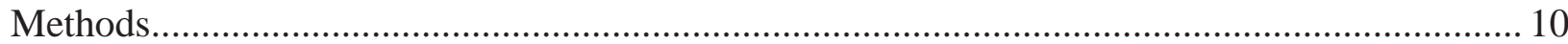

Ecological Integrity Assessment Framework......................................................................... 10

Wetland Classification....................................................................................................... 10

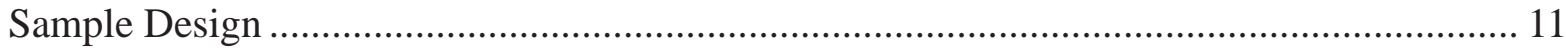

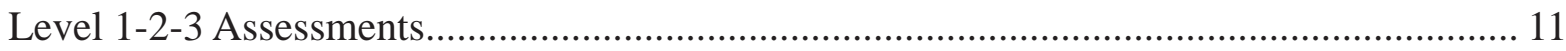

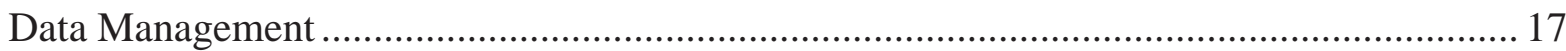

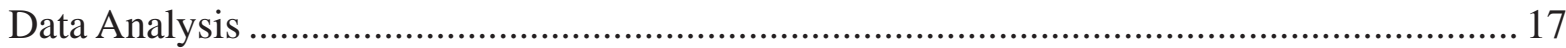

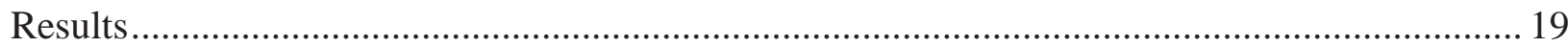

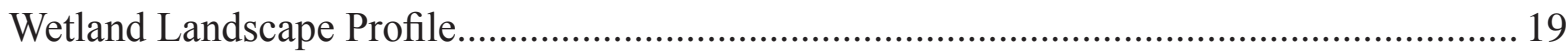

Level 1 Landscape Characterization................................................................................. 20

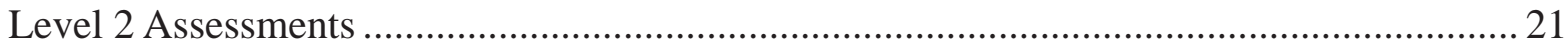

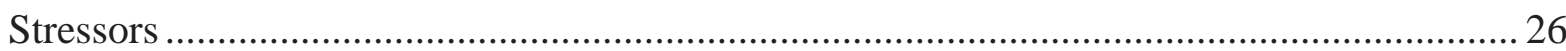

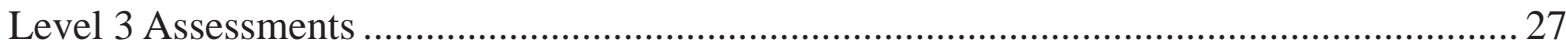

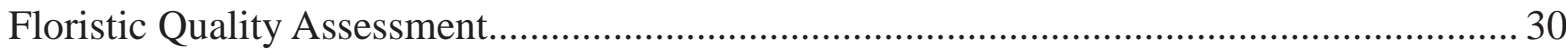

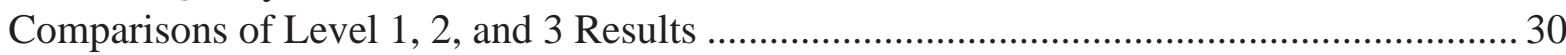

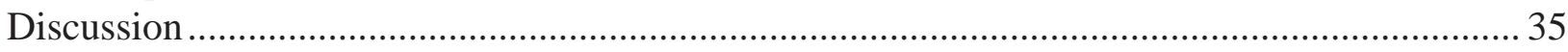

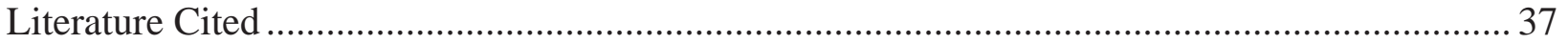

Appendix A: National Wetland Inventory (NWI) attribute codes included in the southwestern Montana basin-wide wetland assessment sample frame.

Appendix B: Palustrine National Wetland Inventory (NWI) attribute codes excluded from the southwestern Montana basin-wide wetland assessment sample frame.

Appendix C: Lacustrine and riverine National Wetland Inventory (NWI) attribute codes excluded from the southwestern Montana basin-wide wetland assessment sample frame.

Appendix D: Scoring procedure for calculating stressor impact ratings

Appendix E: Scoring formulas for Level 2 attribute and overall wetland condition scores

Appendix F: Terminology, description, and calculation of the floristic quality assessment metrics.

Appendix G: Wetland landscape profile for palustrine wetlands in the southwest Montana basin-wide assessment project area.

Appendix H: Level 1 Landscape Characterization Summary

\section{List OF Figures}

Figure 1. Upper Missouri Headwaters, Montana ....................................................................... 2

Figure 2. Southwest Montana basin-wide assessment project area, displaying major rivers and reservoirs................................................................................................. 3 


\section{List of Figures (CONTINUED)}

Figure 3. Land ownership within the southwest Montana basin-wide assessment project area 4

Figure 4. Relative effective annual precipitation (REAP) for the southwest Montana basin-wide assessment project area...... 4

Figure 5. Level IV Ecoregions within the southwest Montana basin-wide assessment project area ................................................................................................ 5

Figure 6. Broad land cover and land use classes of the southwest Montana basin-wide assessment project area................................................................................. 9

Figure 7. Example plot photos from wetland condition assessments in Montana................... 15

Figure 8. Reléve plot layout ....................................................................................... 16

Figure 9. Percent of mapped wetland acres by Cowardin system in the southwest Montana basin-wide assessment project area.................................................... 19

Figure 10. Percent of mapped wetland acres by Cowardin class in the southwest Montana basin-wide assessment project area......................................................... 19

Figure 11. Percent of mapped wetland acres by Cowardin water regime in the southwest Montana basin-wide assessment project area..................................................... 20

Figure 12. Percent of mapped wetland acres by hydrogeomorphic (HGM) system in the southwest Montana basin-wide assessment project area ......................................... 20

Figure 13. Proportion of mapped wetlands classified as anthropogenically altered in the southwest Montana basin-wide assessment project area ........................................ 21

Figure 14. Landscape integrity classes for the southwest Montana basin-wide assessment

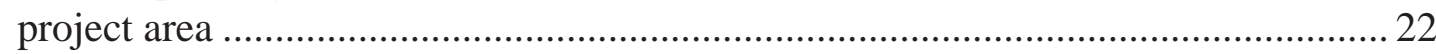

Figure 15. Sampled wetlands by land ownership in the southwest Montana basin-wide

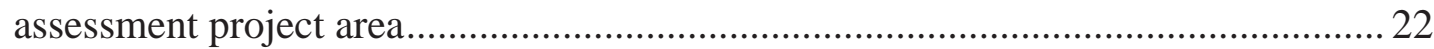

Figure 16. Rocky Mountain Alpine-Montane Wet Meadow site sampled as part of the southwest Montana basin-wide assessment project............................................... 23

Figure 17. Western North American Emergent Marsh site sampled as part of the southwest Montana basin-wide assessment project............................................. 23

Figure 18. Rocky Mountain Subalpine-Montane Riparian Shrubland site sampled as part of the southwest Montana basin-wide assessment project ....

Figure 19. A slope Rocky Mountain Subalpine-Montane Fen site sampled as part of the southwest Montana basin-wide assessment project.............................................. 24

Figure 20. A basin Rocky Mountain Subalpine-Montane Fen site sampled as part of the southwest Montana basin-wide assessment project............................................... 24

Figure 21. Level 2 assessment condition categories for wetlands assessed as part of the southwest Montana basin-wide assessment........................................................ 25

Figure 22. Frequency distribution of C-values of plant species encountered during Level 3 assessments in the southwest Montana basin-wide assessment project .................... 30

Figure 23. Correlation of landscape integrity model (LIM) values with overall Level 2 wetland condition scores 


\section{List OF TABLES}

Table 1. Area of watersheds included in the southwest Montana basin-wide assessment

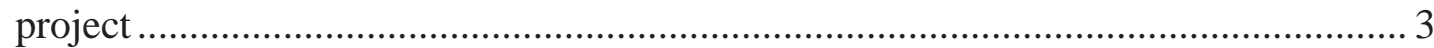

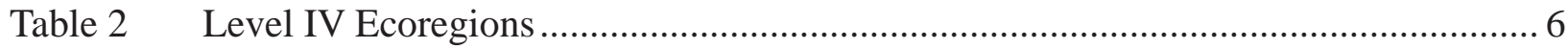

Table 3. Level IV Ecoregions and their corresponding land area within the southwest Montana basin-wide assessment project area.................................................... 8

Table 4. Ecological Integrity Assessment metrics and ecological attributes used in the southwest Montana basin-wide assessment project............................................. 10

Table 5. Wetland landscape profile metrics calculated and their corresponding scale for the southwest Montana basin-wide assessment project .................................... 12

Table 6. Digital data layers and their sources for each Level 1 landscape characterization assessment metric in the southwest Montana basin-wide

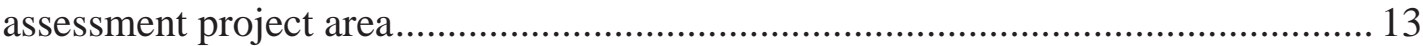

Table 7. Stressor metrics and associated disturbance categories....................................... 14

Table 8. Scope and severity ratings for stressors observed within the assessment area (AA) and within a 200-m envelope around the AA ......................................... 15

Table 9. Sampled wetlands by Ecological System in the southwest Montana

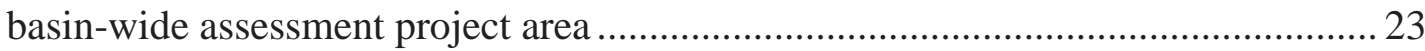

Table 10. Sampled wetlands by hydrogeomorphic system in the southwest Montana

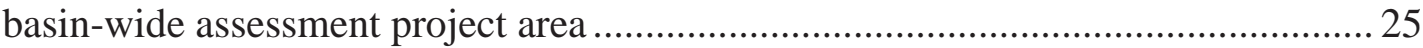

Table 11. Wetland condition category indicating the departure from expected reference standard by wetland ecological system for the southwest Montana basin-wide

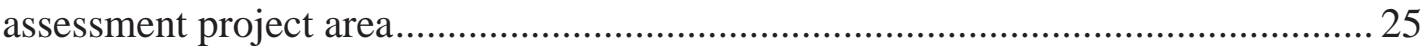

Table 12. EIA attribute condition category indicating the departure from expected reference standard by wetland ecological system for the southwest Montana basin-wide assessment project area .....

Table 13. Stressors observed in the assessment area (AA) and the 200-m envelope around the AA and the corresponding number of sampled wetland sites, categorized by EIA attribute

Table 14. Overall assessment area (AA) stressor impact rating by wetland ecological system for the southwest Montana basin-wide assessment project area

Table 15. EIA attribute stressor impact rating within the assessment area (AA) by wetland ecological system for the southwest Montana basin-wide assessment project area

Table 16. Overall stressor impact rating within the 200-m envelope around the assessment (AA) by wetland ecological system for the southwest Montana basin-wide assessment project area

Table 17. EIA attribute stressor impact rating within the 200-m envelope around the assessment area (AA) by wetland ecological system for the southwest Montana basin-wide assessment project area

Table 18. Ten most commonly encountered plant species during Level 3 intensive assessments in the southwest Montana basin-wide assessment project area

Table 19. Means and standard deviations of all FQA metrics considered by Ecological System for Level 3 assessments completed in the southwest Montana basin-wide assessment project area . 


\section{List of TABLEs (CONTINUED)}

Table 20. Spearman's correlation coefficients of Impact Category scores calculated within a 200-m envelope of the assessment area with Level 2 assessment attribute and overall scores.

Table 21. Spearman's correlation coefficients of Impact Category scores calculated within the assessment area with Level 2 assessment attribute and overall scores .... 32

Table 22. Vegetation metrics included in the floristic quality assessment (FQA), and their response to stressors within the assessment area (AA), within the 200-m envelope surrounding the AA, and their relationship with overall wetland condition scores

Table 23. Stressor extent estimated at Level 3 intensive assessment sites $(n=29)$ at least moderately correlated $(r \geq-0.5)$ with vegetation metrics 


\section{INTRODUCTION}

Although wetlands are uncommon features across the landscape, they provide important functions and ecosystem services that are disproportionate to their abundance, particularly in semiarid portions of Montana and the Rocky Mountain West. Wetlands provide multiple biological and economic benefits such as plant and wildlife habitat, flood attenuation, groundwater recharge, and improvements to water quality. Despite these benefits, wetlands continue to experience pressures from multiple uses including urban, exurban, and agricultural development, as well as resource extraction. Quantifying the impact of these uses on wetland resources requires scientifically sound metrics to assess wetland condition. Additionally, assessments of wetland condition should occur within a watershed context to accurately describe wetland condition at a watershed scale (National Research Council 2001, White and Fennessy 2005, Brooks et al. 2006).

Recognizing these needs, the Montana Natural Heritage Program (MTNHP) initiated a statewide monitoring and assessment program in 2008 to report on the ambient condition of Montana's wetlands. These basin-wide assessments provide regionally specific information on the ecological integrity of wetlands. We adopt Karr and Dudley's (1981) concept of ecological integrity as the ability of an ecosystem to support and maintain its full suite of organisms with species composition, diversity, and function comparable to those of systems in an undisturbed state. Ecological integrity occurs along a continuum of anthropogenic influence or disturbance (Karr and Chu 1999). At one end of this continuum are minimally impacted or least disturbed systems; these systems represent reference standard (Stoddard et al. 2006). With increasing human disturbance, the condition of these systems changes along this continuum.

Our first basin-wide assessment occurred in the Milk, Marias, and St. Mary's watersheds (McIntyre et al. 2011). This report summarizes the results of our second basin-wide assessment of wetlands in the Upper Missouri Headwaters of southwestern Montana. Our objective was to assess wetland condition within six watersheds at multiple spatial scales. We conducted Level 1 GIS analyses that produced: 1) wetland landscape profiles, which summarize information on wetland abundance, type, extent, and function within a given watershed; and 2) a landscape characterization, which characterizes the anthropogenic stressors such as roads and land uses, as well as general information regarding wetland landscape context, using readily available digital datasets. We conducted Level 2 assessments to provide rapid, fieldbased assessments of wetland condition. Finally, Level 3 intensive assessments collected detailed information on the structure and composition of wetland vegetation. This multi-tiered framework allows for the incorporation of multiple scales of assessment, integrating landscape-level information, ambient wetland condition, and sitespecific data. 


\section{Study Area}

\section{Geography}

The study area is the Upper Missouri Headwaters in southwestern Montana (Figure 1). At the initiation of this project, six out of eight basins had complete digital wetland mapping, which was a requirement for inclusion in this multi-scale assessment: Beaverhead River (10020002); Ruby River (10020003); Big Hole River (10020004); Jefferson River (10020005); Madison River (10020007); and Gallatin River (100200008; Figure 2). The six-basin project area covers $6,569,851$ ac $(2,658,735$ ha or $10,265 \mathrm{sq} \mathrm{mi})$ and includes portions of Deer Lodge, Silver Bow, Jefferson, Broadwater, Gallatin, Madison, and Beaverhead counties (Table 1). Major towns in the project area include Dillon, Bozeman, Ennis, and Whitehall. Land uses within this area are primarily livestock grazing with some timber harvesting, mining, and recreation. Residential and commercial development occurs in and around the towns of Dillon and Bozeman. Montane portions of the project area are largely publicly owned, with the
U.S. Forest Service being the primary landowner (Figure 3). Private ownership is focused principally in the valleys and lower foothills.

The project area is characterized by wide intermountain valleys and isolated mountain ranges (Nesser et al. 1997). Mountain ranges are steep with elevations reaching over 10,000 ft (3,048 m). Valleys are glacial and fluvial with alluvial terraces and floodplains. Elevation in the valleys ranges from 2,500 to 6,500 ft (762 to 1,981 m). Elevations of wetlands assessed during this project ranged from 4,081 to $9,383 \mathrm{ft}(1,244$ to $2,860 \mathrm{~m})$.

\section{Climate and Hydrology}

Climate in the study area is cold, dry, and continental (McNab and Avers 1994). Climate data were taken from the Western Regional Climate Center (WRCC 2012). In the valleys, the mean temperatures in January range from $-6^{\circ} \mathrm{C}$ in Dillon and $-10^{\circ} \mathrm{C}$ in Wisdom. In July, mean temperatures range from $18.9^{\circ} \mathrm{C}$ in Dillon to $14.9^{\circ} \mathrm{C}$ in Wisdom.

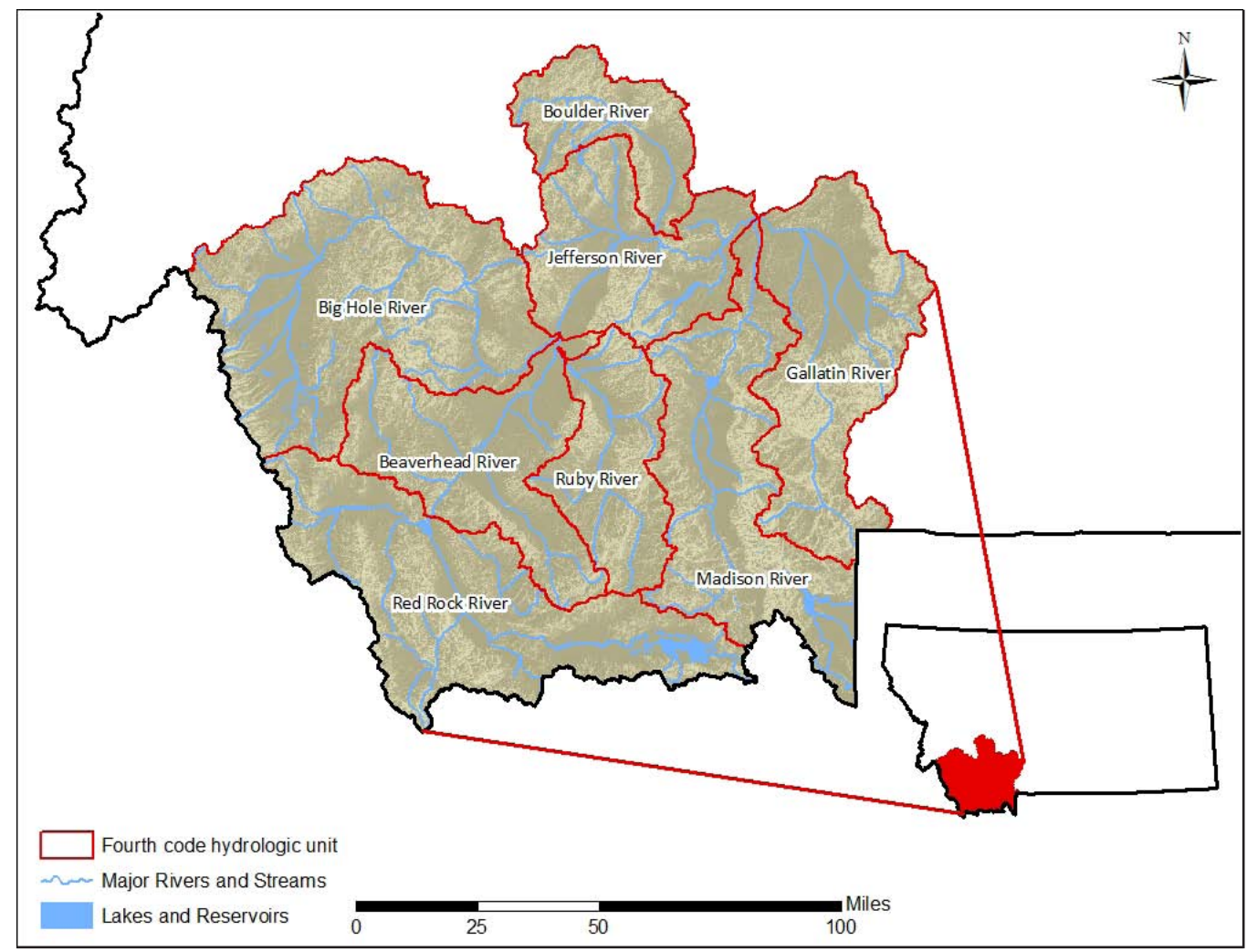

Figure 1. Upper Missouri Headwaters, Montana 


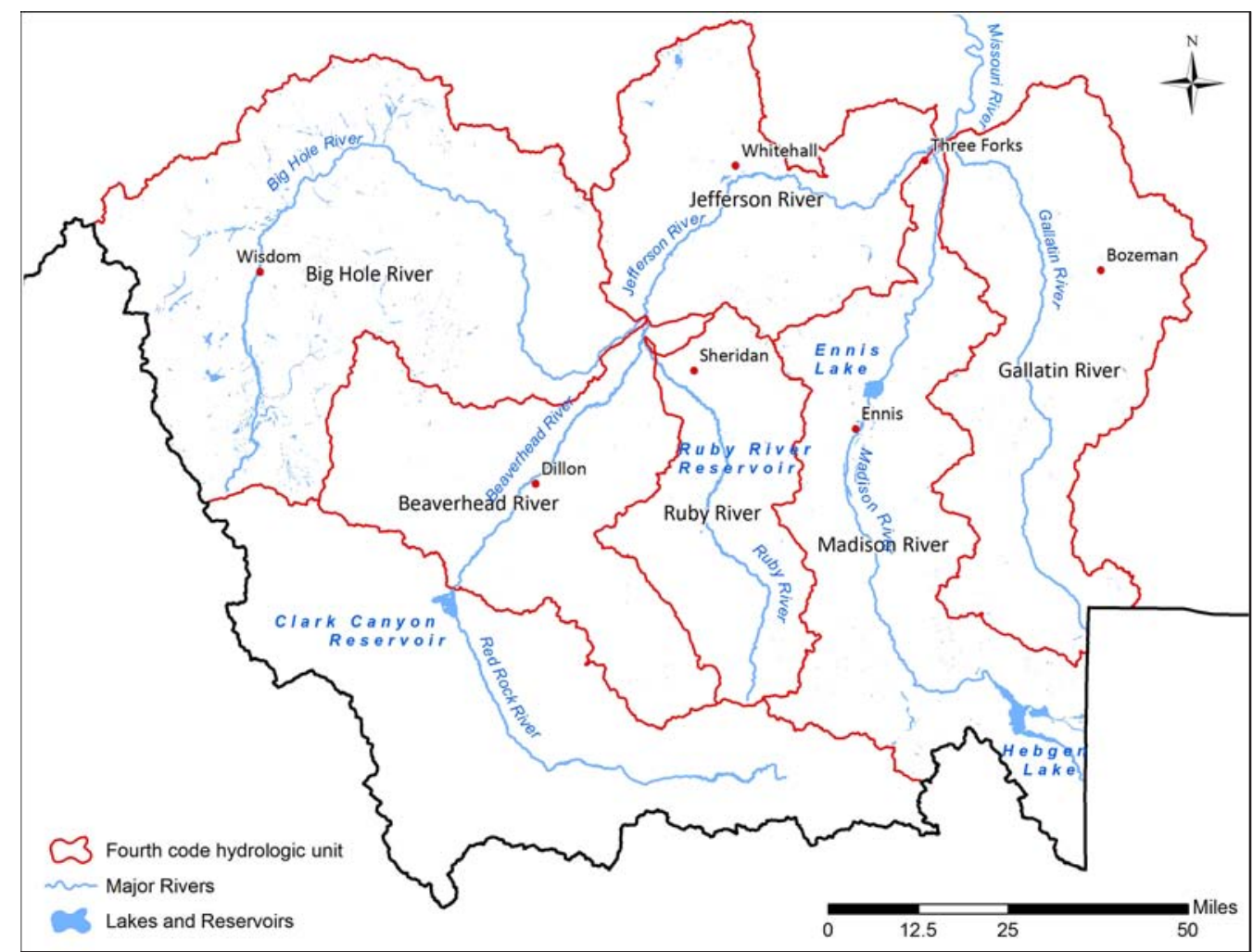

Figure 2. Southwest Montana basin-wide assessment project area, displaying major rivers and reservoirs.

Table 1. Area of watersheds included in the southwest Montana basin-wide assessment project.

\begin{tabular}{lcrrc}
\hline Watershed & $\begin{array}{c}\text { 8-digit } \\
\text { hydrologic } \\
\text { unit code }\end{array}$ & Acres & Hectares & $\begin{array}{c}\text { \% of } \\
\text { Project } \\
\text { Area }\end{array}$ \\
\hline Beaverhead River & 10020002 & 961,260 & 389,010 & $15 \%$ \\
Big Hole River & 10020004 & $1,784,832$ & 722,299 & $27 \%$ \\
Gallatin River & 10020008 & $1,140,749$ & 461,647 & $17 \%$ \\
Jefferson River & 10020005 & 831,274 & 336,406 & $13 \%$ \\
Madison River & 10020007 & $1,233,759$ & 499,287 & $19 \%$ \\
Ruby River & 10020003 & 617,977 & 250,087 & $9 \%$ \\
\hline & & $6,569,852$ & $2,658,736$ &
\end{tabular}

Mean annual precipitation at these stations is 246 $\mathrm{mm}$ and $305 \mathrm{~mm}$, respectively. Precipitation values are considerably higher in the eastern portion of the study area, with mean annual precipitation values of $470 \mathrm{~mm}$ in Bozeman and $549 \mathrm{~mm}$ in West Yellowstone. The relative effective annual precipitation (REAP), which is an indicator of the amount of moisture available at a given location accounting for precipitation, slope, aspect, and soil properties, ranges from a low of $13 \mathrm{~cm}$ in the western and central valleys in the project area, to $150 \mathrm{~cm}$ at the highest elevations (Figure 4).

Streams and rivers in the project area make up the Headwaters of the Missouri River, although the true source of the Missouri River is just outside the project area in the Red Rock River watershed at Hell Roaring Creek. The Ruby River is a tributary of the Beaverhead River. The Beaverhead and the Big Hole Rivers comprise the Jefferson River. 


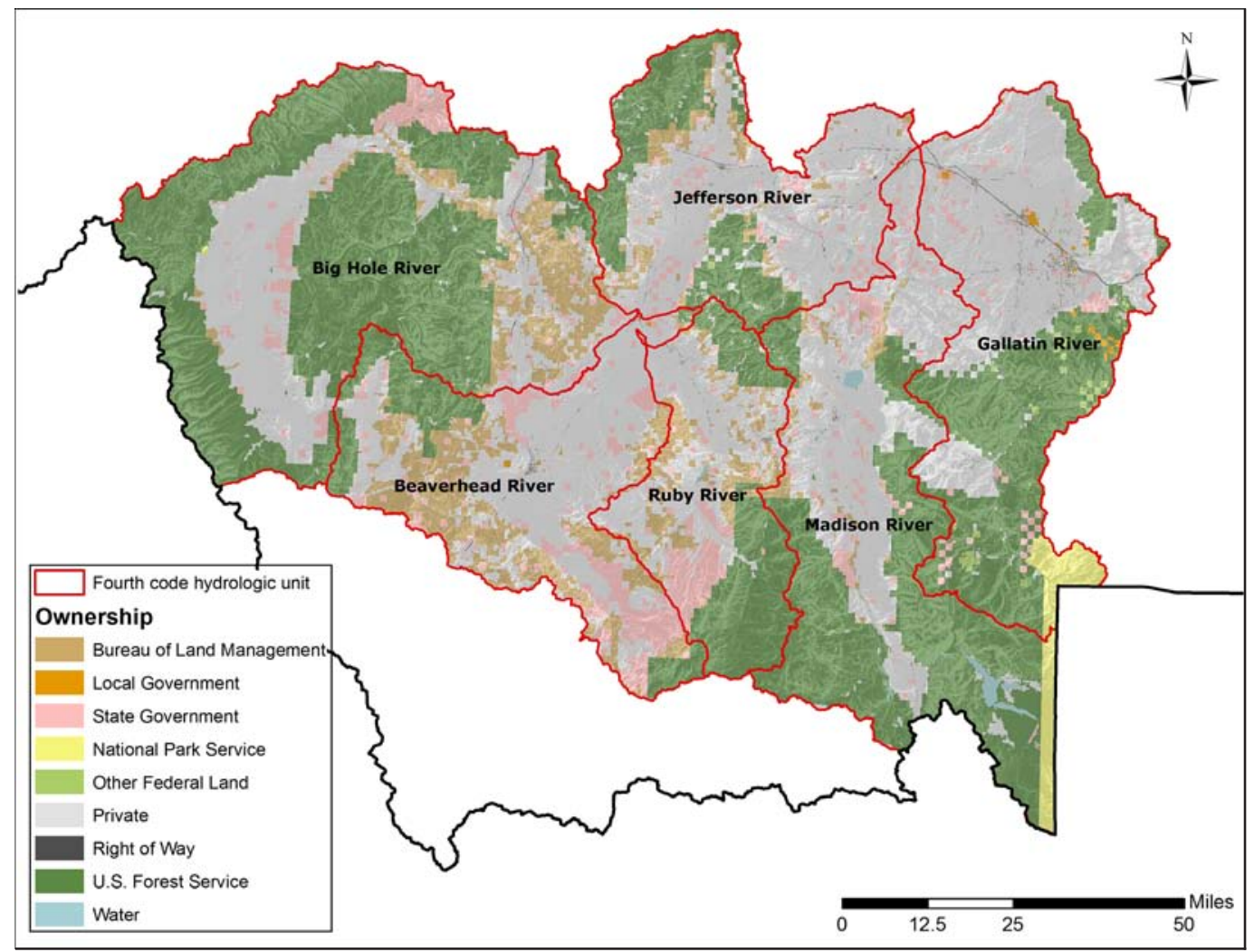

Figure 3. Land ownership within the southwest Montana basin-wide assessment project area.

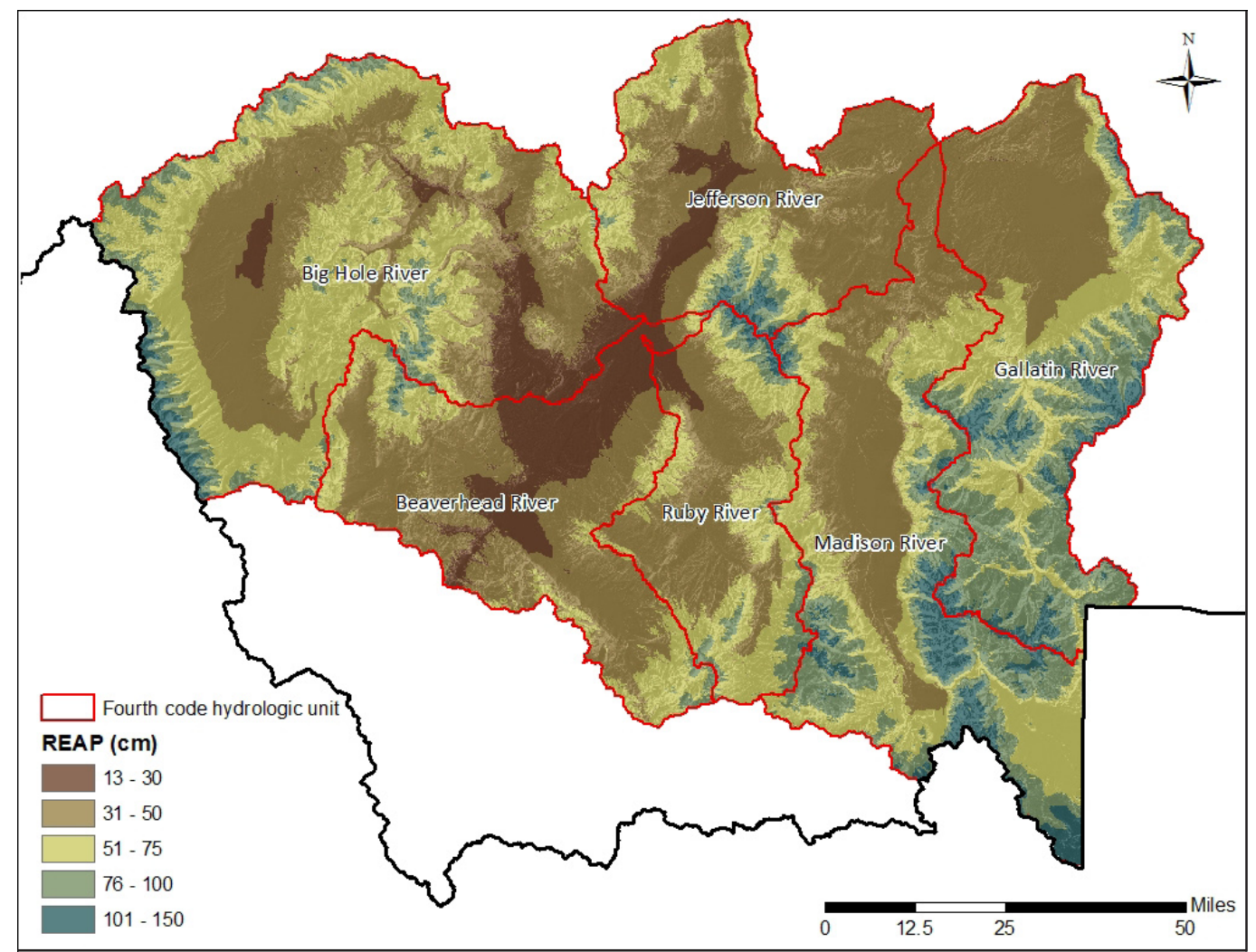

Figure 4. Relative effective annual precipitation (REAP) for the southwest Montana basin-wide assessment project area. 
Finally, the Gallatin, the Jefferson, and the Madison meet at the town of Three Forks to form the Missouri River. Major reservoirs influencing the project area include Ruby River Reservoir (Ruby River), Clark Canyon Reservoir (Beaverhead River), Ennis Lake (Madison River), and Hebgen Lake (Madison River; Figure 2).

\section{Ecoregions and Vegetation}

The project area lies entirely within the Middle Rockies Level III ecoregion (Omernik 1987). Level IV Ecoregions further subdivide the area into 20 different units based on geology and dominant vegetation (Figure 5; Table 2 and 3). Montane portions of the project area are dominated by coniferous forest, while lower elevations are composed of shrublands and grasslands (Figure 6). Dominant coniferous species vary by elevation with lower elevation forests composed of Douglasfir (Pseudotsuga menziesii) with limber pine (Pinus flexilis) and Rocky Mountain juniper (Juniperus scopulorum) common on calcareous sites. Higher elevation forests are dominated by subalpine fir (Abies lasiocarpa), lodgepole pine ( $P$. contorta), and Engelmann spruce (Picea engelmannii). Upland plant communities below treeline are composed of shrublands and grasslands. Shrublands are dominated by mountain big sagebrush subspecies (Artemisia tridentata ssp. vaseyana) although basin big sagebrush (A. t. ssp. tridentata) and Wyoming big sagebrush (A. t. ssp. wyomingensis) are locally common. Additionally, extensive stands of threetip sagebrush (A.

tripartita) also occur. Large stands of greasewood (Sarcobatus vermiculatus) occur on saline or alkaline sites. The herbaceous layer is dominated by bunchgrasses, including bluebunch wheatgrass (Pseudoroegneria spicata), Idaho fescue (Festuca idahoensis), and needle and thread (Hesperostipa comata).

Larger rivers support riparian forests dominated by black cottonwood (Populus balsamifera ssp. trichocarpa), although cottonwoods are almost entirely absent from some rivers (e.g., Beaverhead River and upper Big Hole River). Open canopy

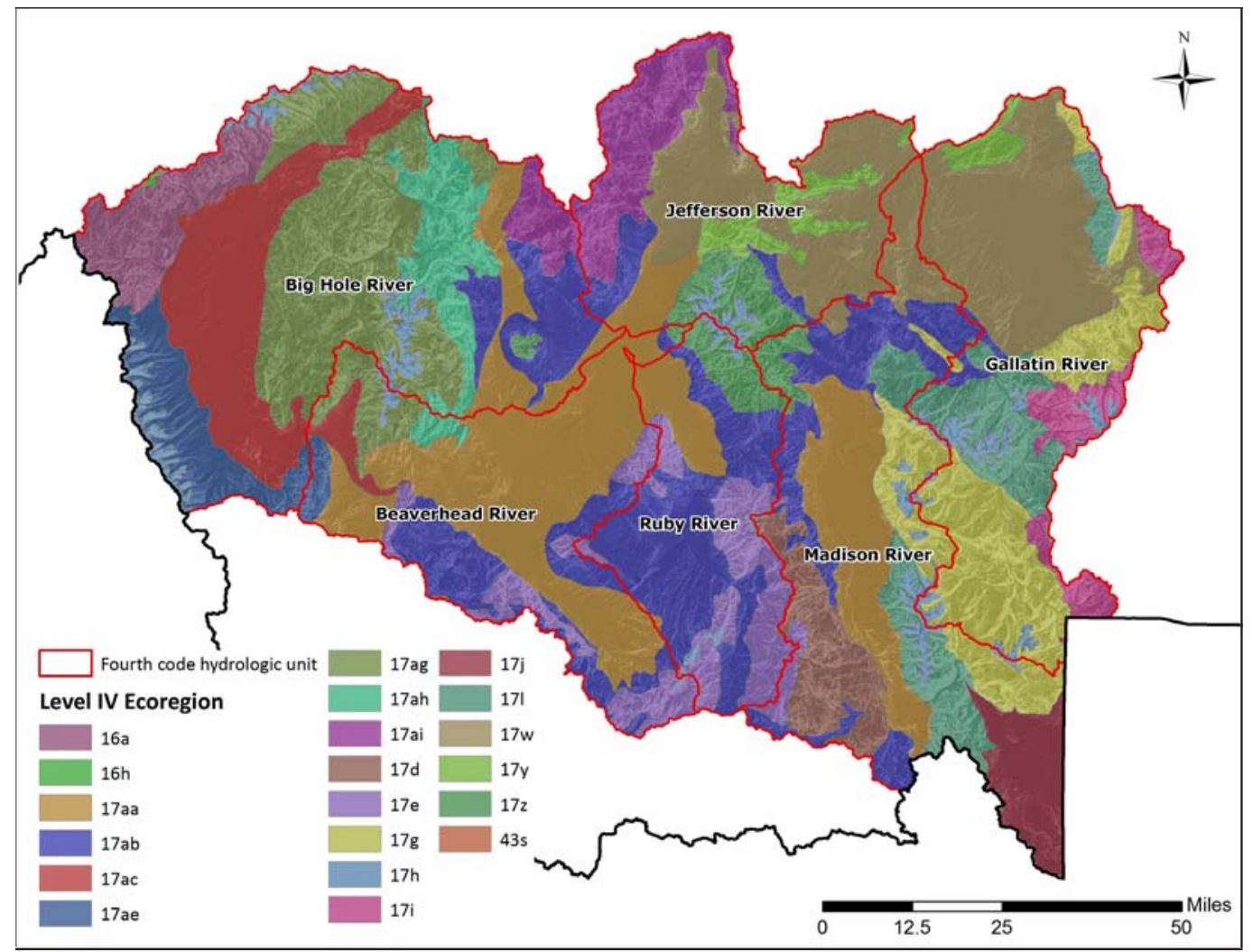

Figure 5. Level IV Ecoregions within the southwest Montana basin-wide assessment project area. See Table 2 for Level IV Ecoregion names and descriptions. 
Table 2. Level IV Ecoregions (taken from Woods et al. 1999).

- 16a. The Eastern Batholith ecoregion is forested and mountainous and lies northwest of the Continental Divide. Characteristically, Ecoregion 16a is underlain by intrusive rocks of the Cretaceous Idaho Batholith and, in consequence, its surface waters are very low in alkalinity. The climax vegetation is subalpine fir, Douglas-fir, and ponderosa pine.

- 16h. The High Idaho Batholith contains jagged peaks, tarns, and rockland. It is often snowcapped and annual precipitation is greater than in nearby, lower ecoregions. Soils are shallow, stony, and have a cryic temperature regime. Ecoregion 16h includes alpine areas, subalpine parkland, and very high, open, wind-blown forests composed mostly of nonmarketable subalpine fir and whitebark pine. Tundra, alpine grassland, subirrigated meadows, and wetlands are found above treeline.

- $\quad$ 17d. The Eastern Gravelly Mountains ecoregion has subdued, pothole-studded terrain and is mostly forested. Climax vegetation is mapped as subalpine fir and Douglas-fir forests. Ecoregion 17d is underlain by a variety of rocks. Its core consists of folded and faulted, generally carbonate-rich, Mesozoic and Paleozoic sedimentary rocks, whereas lower slopes are underlain by Precambrian pre-Belt metamorphic and metasedimentary rocks and Tertiary rhyolite.

- $\quad$ 17e. The Barren Mountains ecoregion is commonly underlain by carbonate-rich sedimentary rocks. Elevations range from about 5,600 to just over 11,100 ft but only a few areas were glaciated. High, forested peaks are mainly composed of carbonate-rich Mesozoic and Paleozoic sedimentary rocks and Tertiary volcanics. Lower, less forested areas tend to be underlain by Precambrian rock. Climax vegetation is subalpine fir and Douglas-fir forests. The forested belt is often very limited; lower treeline elevation occurs somewhere between 5,600 and 7,000 ft. Forest stands commonly have an undergrowth of grass, which can be sparse due to the semiarid conditions.

- $\quad$ 17g. The Mid-Elevation Sedimentary Mountains ecoregion is mostly forested and partially glaciated. Ecoregion $17 \mathrm{~g}$ is characteristically underlain by faulted and folded Mesozoic and Paleozoic sedimentary rocks, including limestone. Climax vegetation is mapped as subalpine fir and Douglas-fir forests.

- $\quad$ 17h. The Alpine Zone ecoregion was glaciated and is characterized by jagged peaks, mixed high altitude vegetation, many tarns, rockland, and talus deposits. Elevations range from about 8,500 to just over $12,500 \mathrm{ft}$. Average annual precipitation ranges from 30 to 100 inches and exceeds that of surrounding, but lower, ecoregions. Ecoregion $17 \mathrm{~h}$ is often snowcapped for most of the year; permafrost occurs sporadically and solifluction has created patterned-ground in the alpine areas of the Beartooth Plateau. The soils are Udic-Cryic Inceptisols and are typically very gravelly to stony. They support subalpine fir and whitebark pine forests in glacial cirques. Above timberline, alpine tundra, alpine grassland, subirrigated meadows, and wetlands occur. Krummholz vegetation occupies windswept areas between the forest and higher alpine areas.

- 17i. The Absaroka-Gallatin Volcanic Mountains ecoregion has rock outcrops, volcanic mud flows, and extensive glacial drift and colluvial deposits. Ecoregion $17 \mathrm{i}$ is underlain primarily by pyroclastic material, Tertiary volcanic flows, and water-laid volcanics. Percolation rates are high and water tables are commonly perched, especially in unglaciated areas. Springs and wetlands are common. Climax vegetation is mapped as subalpine fir and Douglas-fir forests.

- $\quad$ 17ae. The Forested Beaverhead Mountains ecoregion is characterized by pothole lakes, drift deposits, boggy areas, and gentle lower slopes. Ecoregion 17ae is underlain by Precambrian argillite, quartzite, argillaceous rocks, carbonates, and shales. Climax vegetation is subalpine fir and Douglas-fir forests. Ecoregion 17ae receives an average annual precipitation of 20 to just over 40 inches. Streams are typically low in turbidity except during high discharge events, which accompany thunderstorms and spring snow melt.

- 17ag. The Pioneer-Anaconda Ranges ecoregion is glaciated and forested. It lies southeast of the Continental Divide and contains glacial drift, many lakes, and wetlands. Ecoregion 17ag is underlain by sedimentary and metasedimentary rocks. Climax vegetation is subalpine fir and Douglas-fir forests. Average annual precipitation ranges from 16 to about 40 inches.

- 17ah. The Eastern Pioneer Sedimentary Mountains ecoregion lies south of the Continental Divide and is mostly forested. It is characterized by Paleozoic and Mesozoic sedimentary rocks. Limestone is common and strongly affects water quality, available water quantity, soils, and aquatic biota. Granitic intrusions occur and have locally reacted with limestone to produce zones of skarn that have been mined for the tungsten mineral scheelite. Average annual precipitation ranges from 12 to 20 inches. The Eastern 
Pioneer Sedimentary Mountains (17ah) ecoregion was glaciated. Climax vegetation is subalpine fir and Douglas-fir forests.

- 17ai. The Elkhorn Mountains-Boulder Batholith ecoregion straddles the Continental Divide and is underlain by Cretaceous and Tertiary intrusive and extrusive rocks; areas of unique boulder-strewn topography occur and are composed of erosion-prone andesitic rocks. Both mining and related environmental impacts are common and most of the major known deposits of copper, zinc, lead, silver, and gold in Montana are associated with the Boulder Batholith. Annual precipitation is much less than in the mountains to the northwest and averages 12 to 30 inches. The climax vegetation is subalpine fir and Douglas-fir forests.

- 17w. The Townsend Basin lies east of the Continental Divide and contains floodplains, stream terraces, alluvial fans, and hills. It is mostly composed of Quaternary alluvium and Tertiary valley fill. Potential natural vegetation consists of foothills prairie and grama-needlegrass-wheatgrass.

- $17 \mathrm{j}$. The Yellowstone Plateau ecoregion is characterized by subdued topography and contains lakes, springs, hot springs, wetlands, and hills. Ecoregion $17 \mathrm{j}$ is composed of Quaternary alluvial fill deposits, terrace deposits, colluvium, and glacial drift. The climax vegetation of the Yellowstone Plateau (17j) is Douglas-fir forest.

- $\quad$ 17l. The Gneissic-Schistose Forested Mountains ecoregion is wet and mostly forested. Ecoregion 171 is characteristically underlain by Precambrian pre-Belt gneiss and schist and rock outcrops occur. Low stream flows occur during drought and freezing periods. Typically, there is only a short time lag between rainfall and runoff peak and, consequently, storm hydrographs are flashy. Average annual precipitation ranges from less than 20 to 100 inches. The climax vegetation is subalpine fir and Douglas-fir forests.

- 17y. The Townsend-Horseshoe-London Sedimentary Hills ecoregion lies in the rainshadow of the Elkhorn Mountains and is rather dry. It is largely composed of Mesozoic and Paleozoic sedimentary rock; limestone is common and both caverns and dry valleys occur. Elevations range from about 4,000 to 8,200 $\mathrm{ft}$.

- $\quad$ 17z. The Tobacco Root Mountains ecoregion is characterized by a Tertiary granitic core and is geographically isolated from neighboring mountainous ecoregions. Average annual precipitation ranges from about 16 to 40 inches. The climax vegetation is subalpine fir and Douglas-fir.

- 17aa. The Dry Intermontane Sagebrush Valleys ecoregion is composed of alluvium, fan, and valley-fill deposits. Characteristically, the potential natural vegetation is sagebrush steppe. The growing season ranges from 70 to 110 days.

- $\quad$ 17ab. The Dry Gneissic-Schistose-Volcanic Hills ecoregion is underlain by Precambrian pre-Belt rocks and Tertiary volcanics. Elevations range from about 4,800 to 9,600 ft. The potential natural vegetation is mostly sagebrush steppe.

- $\quad$ 17ac. The Big Hole ecoregion is a low-relief, high elevation valley containing meadows, extensive wetlands, floodplains, swampy creeks, many springs, broad stream terraces, and alluvial fans. The growing season averages about 30 days. The potential natural vegetation is sagebrush steppe.

- 43s. The Non-calcareous Foothill Grassland ecoregion slopes down from the lower mountain treeline to the plains. Its hills and scattered buttes are dissected by shrub- and tree-covered, mountain-fed streams. Potential natural vegetation is mostly foothills prairie. A variety of mostly non-carbonate rocks underlie Ecoregion 43s.

riparian forests, which are often a consequence of upstream impoundments or on-site livestock grazing, typically have little shrub development in the understory, although western snowberry (Symphoricarpos occidentalis) and Wood's rose (Rosa woodsii) frequently occur. Closed canopy riparian forests have a complex shrub layer with redosier dogwood (Cornus sericea), yellow willow (Salix lutea), and chokecherry (Prunus virginiana). Historically, the herbaceous component consisted of native grasses including western wheatgrass
(Pascopyrum smithii), basin wildrye (Leymus cinereus), and thickspike wheatgrass (Elymus lanceolatus). In many areas, these grasses have been replaced by exotic pasture grasses including Kentucky bluegrass (Poa pratensis) and smooth brome (Bromus inermis).

Smaller streams and some of the larger rivers are dominated by several willow species, including Geyer willow (Salix geyeriana), Drummond's willow (S. drummondiana), and Booth's willow 
Table 3. Level IV Ecoregions and their corresponding land area within the southwest Montana basinwide assessment project area.

\begin{tabular}{lcrr}
\hline Level IV Ecoregion Name & Code & Acres & Hectares \\
\hline Eastern Batholith & $16 \mathrm{a}$ & $178,394.0$ & $72,193.7$ \\
High Idaho Batholith & $16 \mathrm{~h}$ & $2,518.8$ & $1,019.3$ \\
South Clearwater Forested Mountains & $16 \mathrm{i}$ & 0.5 & 0.2 \\
Dry Intermontane Sagebrush Valleys & $17 \mathrm{a}$ & $995,445.0$ & $402,844.0$ \\
Dry Gneissic-Schistose-Volcanic Hills & $17 \mathrm{ab}$ & $934,594.0$ & $378,218.0$ \\
Big Hole & $17 \mathrm{ac}$ & $401,203.0$ & $162,362.0$ \\
Forested Beaverhead Mountains & $17 \mathrm{ae}$ & $181,539.0$ & $73,466.5$ \\
Pioneer-Anaconda Ranges & $17 \mathrm{ag}$ & $593,315.0$ & $240,107.0$ \\
Eastern Pioneer Sedimentary Mountains & $17 \mathrm{ah}$ & $186,966.0$ & $75,662.7$ \\
Elkhorn Mountains-Boulder Batholith & $17 \mathrm{ai}$ & $249,945.0$ & $101,150.0$ \\
Eastern Gravelly Mountains & $17 \mathrm{~d}$ & $166,044.0$ & $67,195.9$ \\
Barren Mountains & $17 \mathrm{e}$ & $297,757.0$ & $120,498.0$ \\
Mid-elevation Sedimentary Mountains & $17 \mathrm{~g}$ & $498,490.0$ & $201,732.0$ \\
Alpine Zone & $17 \mathrm{~h}$ & $196,238.0$ & $79,414.9$ \\
Absaroka-Gallatin Volcanic Mountains & $17 \mathrm{i}$ & $115,390.0$ & $46,696.8$ \\
Yellowstone Plateau & $17 \mathrm{j}$ & $129,448.0$ & $52,386.2$ \\
Gneissic-Schistose Forested Mountains & $17 \mathrm{l}$ & $310,290.0$ & $125,570.0$ \\
Townsend Basin & $17 \mathrm{w}$ & $841,297.0$ & $340,462.0$ \\
Townsend-Horseshoe-London Sedimentary Hills & $17 \mathrm{y}$ & $115,599.0$ & $46,781.3$ \\
Tobacco Root Mountains & $17 \mathrm{z}$ & $173,195.0$ & $70,089.9$ \\
Non-calcareous foothill grassland & $43 \mathrm{~s}$ & 110.4 & 44.7 \\
\hline
\end{tabular}

(S. boothii). The herbaceous component consists of Northwest Territory sedge (Carex utriculata), water sedge (C. aquatilis), and tufted hairgrass (Deschampsia cespitosa). A diversity of wetlands exists throughout the project area, ranging from large floodplain marshes to fens to extensive wet meadows. Wetland communities are described in greater detail in the Results section, below. 


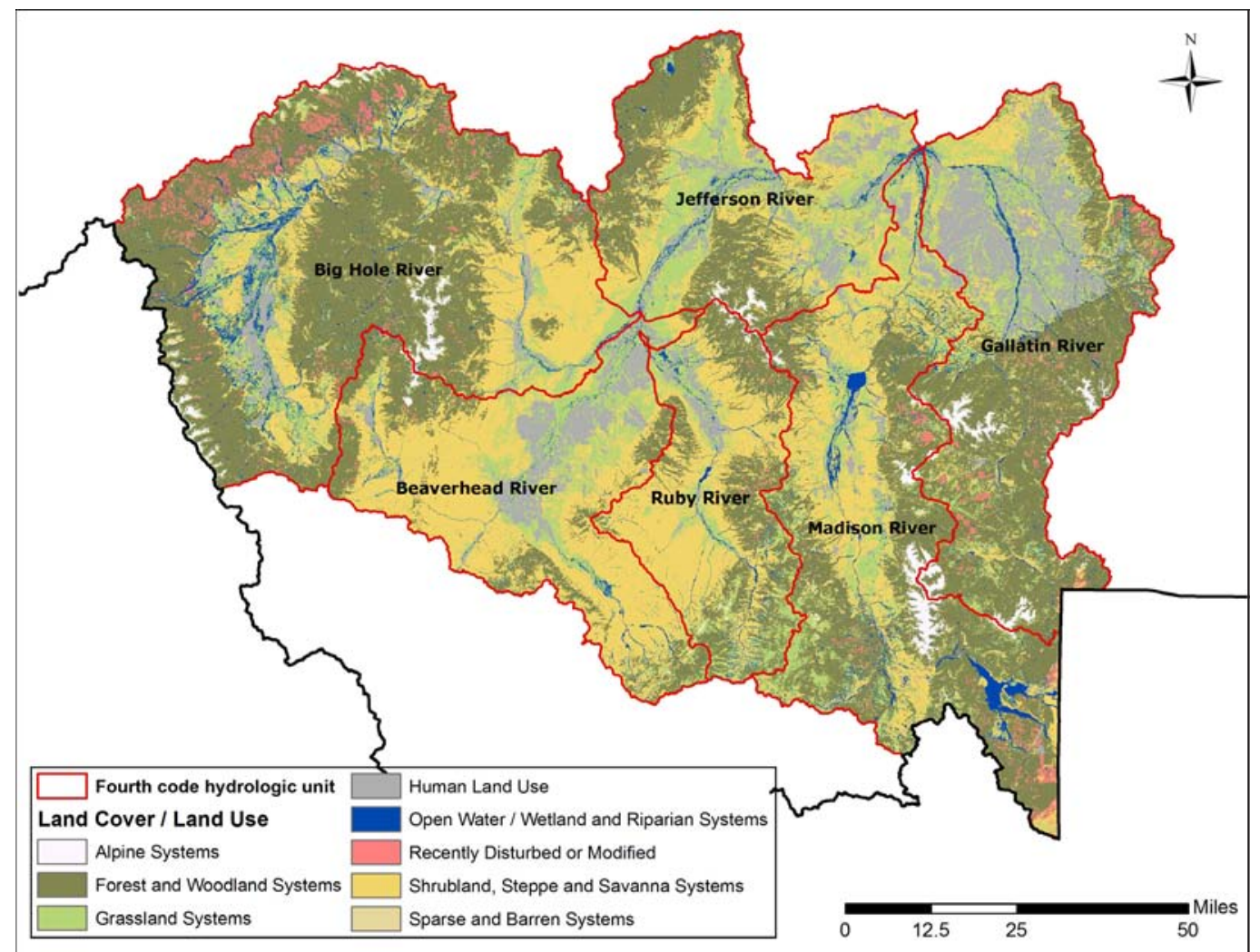

Figure 6. Broad land cover and land use classes of the southwest Montana basin-wide assessment project area (MTNHP 2012). 


\section{Methods}

\section{Ecological Integrity Assessment Framework}

The MTNHP uses an Ecological Integrity Assessment (EIA) framework to assess the condition of wetlands. An EIA relies upon the identification of key ecological indicators or metrics and stressors that can be readily measured, monitored, or observed. The indicators reflect both the structure and function of the wetland. Metrics consist of narrative ratings and are scaled along a gradient reflecting wetland condition relative to a natural or undisturbed state (i.e., reference standard). Ideally, metrics should be unambiguous, mutually exclusive, and equally distributed along a disturbance gradient, allowing the observer to best describe the observed state (Sutula et al. 2006). Metric ratings are assigned on an ordinal scale, resulting in reduced measurement error and repeatable results. EIA metric ratings are integrated to produce overall scores for four attributes: 1) Landscape Context; 2) Biotic Structure and Composition; 3) Physicochemical; and 4) Hydrology. The ratings for these four attributes can be combined to produce an overall EIA score (Table 4).

We assessed wetland integrity at three levels. Level 1 GIS landscape analyses consist of: 1) wetland landscape profiles, which use digital wetland mapping to summarize information on wetland abundance, type, extent, and function across the watershed (Johnson 2005); and 2) a landscape characterization of the distribution of anthropogenic stressors such as roads and land use in relation to wetlands, as well as general information regarding wetland landscape context. Level 2 field-based assessments collect data on the general condition of individual wetlands. Level 3 assessments collect detailed quantitative data using indices of biological integrity.

\section{Wetland Classification}

Natural variability occurs both within wetland classes (e.g,. wet meadows can occur at either

Table 4. Ecological Integrity Assessment metrics and ecological attributes used in the southwest Montana basin-wide assessment project.

\begin{tabular}{ll}
\hline Attribute & Metric \\
\hline Landscape Context & Landscape Connectivity \\
& Buffer Width \\
& Buffer Length \\
& Buffer Condition \\
& Relative Cover of Native Plant Species \\
& Relative Cover of Tolerant Native Plant Species \\
Vegetation & Relative Cover of Noxious Plant Species \\
& Herbaceous Litter/Woody Debris Accumulation \\
& Interspersion of Plant Zones \\
& Woody Species Establishment and Regeneration \\
& Utilization of Trees and Shrubs \\
& Soil Surface Integrity \\
Physicochemical & Water Quality: Algae, Plants, and Turbidity \\
Hydrology & Water Inputs \\
& Water Outlets \\
& Hydroperiod \\
& Surface Water Connectivity \\
\hline
\end{tabular}


alpine or lower montane elevations but differ in plant diversity and productivity) and among wetland classes (e.g., fens differ in hydrology, soils, and plant communities from freshwater marshes). Providing a classification framework to distinguish wetland systems helps reduce within class variability and enhance detection of differences in condition among wetlands. Common wetland classification systems include the Cowardin classification system (Cowardin et al. 1979) and the hydrogeomorphic (HGM) classification system (Brinson 1993). Standardized classifications have also been developed via the National Vegetation Classification (NVC; Grossman et al. 1998) and the Ecological Systems classification in the United States (Comer et al. 2003). For the purpose of this project, we used the Ecological Systems classification. This classification system provides a valuable means of classifying wetland systems because it uses both biotic (vegetation physiognomy and floristics) and abiotic (geologic, hydrologic, elevation, edaphic) criteria to define landscape units. Ecological Systems can be crosswalked to other classification systems including the NVC, Cowardin, and HGM systems. Additionally, they capture the range of natural variability in wetlands while organizing them into manageable conceptual units.

\section{Sample Design}

We included all digitally mapped wetlands from National Wetlands Inventory (NWI) mapping to produce wetland landscape profiles for the project area. For the Level 1 landscape characterization and Level 2 and Level 3 wetland assessments, the target population included all mapped vegetated wetlands and excluded lacustrine (deepwater lakes), riverine (wetlands and deepwater habitats contained with the channel), and artificially flooded wetlands from the target population. We also excluded wetlands smaller than 0.1 ha.

The target number of sample sites was 1,000 wetlands for Level 1 landscape characterization; 100 wetlands for Level 2 assessment; and 30 wetlands for Level 3 assessment.

The sample frame was drawn from digital wetland polygons. MTNHP created digital wetland mapping for the project area using 2005 color infrared imagery. A list of NWI types included in the sample frame can be found in Appendix A. A list of NWI types excluded from the sample frame can be found in Appendices B and C.

We followed a spatially balanced sampling approach (Stevens and Olsen 2004, Stevens and Jensen 2007) to select wetlands for assessment. This approach allowed us to account for the spatial patterning inherent in ecological systems (e.g., sites in close proximity tend to be more similar than widely separated sites). Spatially balanced sampling is also more efficient than simple random sampling by minimizing the redundancy inherent in a simple random sample, which might select multiple proximate sites (Stevens and Jensen 2007). The sample design followed a Generalized Random Tessellation Stratified (GRTS) procedure for discrete objects with reverse hierarchical randomization, where polygons within the sample frame were the discrete objects and their locations were identified by their centroids. We selected approximately 1,000 wetlands, stratifying by Level IV ecoregion. GRTS sampling was performed using package spsurvey (Kincaid and Olsen 2009) in R (R Development Core Team 2009). Using aerial imagery in a GIS, we examined each selected wetland to ensure it still existed and was accessible until we had approximately 100 wetlands selected for Level 2 field assessments. We conducted intensive Level 3 assessments at approximately $30 \%$ of these 100 wetlands.

\section{Level 1-2-3 Assessments}

\section{Level 1-Wetland Landscape Profiling}

Using digital wetland mapping, we prepared a wetland landscape profile for the project area. A wetland landscape profile provides a broad landscape characterization of the wetlands within a particular area at the basin, watershed, or subwatershed level. The profile summarizes wetland acreage by: Cowardin system; class; hydrologic regime; land ownership; hydrogeomorphic class; potential wetland function; and the extent of wetlands that have been anthropogenically altered (Table 5). 
Table 5. Wetland landscape profile metrics calculated and their corresponding scale for the southwest Montana basin-wide assessment project.

\begin{tabular}{lcc}
\hline \multicolumn{1}{c}{ Metric } & $\begin{array}{c}\text { Calculated } \\
\text { for Entire } \\
\text { Project Area }\end{array}$ & $\begin{array}{c}\text { Calculated } \\
\text { for Each } \\
\text { Watershed }\end{array}$ \\
\hline Wetland System (\%) & $\mathrm{X}$ & \\
Wetland Class (\%) & $\mathrm{X}$ & \\
Wetland Water Regime (\%) & $\mathrm{X}$ & \\
Hydrogeomorphic Class (\%) & $\mathrm{X}$ & \\
Acres of altered wetlands & $\mathrm{X}$ & \\
Acres of potential wetland function & $\mathrm{X}$ & $\mathrm{X}$ \\
Acres of altered palustrine wetlands & $\mathrm{X}$ & $\mathrm{X}$ \\
Acres of palustrine wetlands on private lands & $\mathrm{X}$ & $\mathrm{X}$ \\
Acres of palustrine wetlands on public lands & $\mathrm{X}$ & $\mathrm{X}$ \\
\hline
\end{tabular}

\section{Level 1-Landscape Characterization}

We derived potential landscape indicators from available digital datasets including land use, hydrology, roads, and climate (Table 6). Landscape characterization was performed in a GIS at four spatial scales: the wetland polygon; the $100-\mathrm{m}$ envelope; the 300-m envelope; and the 1,000-m envelope around the perimeter of the mapped wetland polygon. Road densities, the density of hydrologic modifications such as canals/ditches, wells, and water rights were also calculated. Land uses surrounding selected wetland polygons was characterized using Montana Land Cover (MTNHP 2010a) and the Montana Department of Revenue Final Land Unit Classification (Montana Department of Revenue 2010). Percent land use was calculated for each spatial scale. Percent land use in the envelope surrounding the wetland polygon was calculated beginning at the wetland boundary, so this value changed with the size of the wetland polygon. Distance measures included distance to the nearest local road (unpaved and rural roads), distance to the nearest canal or ditch, and distance to the nearest well.

We also calculated several metrics that provided indicators of the ability of wetlands to perform habitat functions. Wetland perimeter to area ratio was calculated for each selected wetland polygon as an indicator of the wetland's ability to provide habitat for interior-dependent versus edge-dwelling species (Helzer and Jelinski 1999). The distance to the nearest five wetlands was calculated to provide an indicator of connectivity among wetlands (Gibbs 1993). The size of each selected wetland polygon was also calculated.

Additionally, we applied a landscape integrity model (LIM) to the project area, which assigned a value to each $30 \mathrm{~m} \times 30 \mathrm{~m}$ pixel in a raster dataset based on that pixel's distance from anthropogenic disturbances and land uses such as roads, agriculture, and mining. The effect of an anthropogenic disturbance on that pixel was assumed to decrease with increasing distance. See Vance (2009) for detailed discussion of the model's development.

\section{Level 2 Rapid Assessments}

Field methods for Level 2 assessments are detailed in the Montana Ecological Integrity Assessment Field Manual (MTNHP 2010b). Level 2 assessments take approximately two hours to complete. At each sample wetland point, we established an assessment area (AA) for sampling. The AA was established within a portion of the wetland representing the same Ecological System type within a 0.5 ha area around the sample point. Prior to field visits, we created a set of field maps for each targeted sample point. The field maps outline the potential AA boundary and multiple radial buffers around the AA. These buffers are used in several of the landscape context metrics. 
Table 6. Digital data layers and their sources for each Level 1 landscape characterization assessment metric in the southwest Montana basin-wide assessment project area.

\begin{tabular}{|c|c|c|}
\hline Attribute & Metric & Data Source \\
\hline \multirow{4}{*}{ Transportation } & Density of 4-wheel drive roads (m/ha) & ftp://ftp2.census.gov/geo/tiger/TIGER2009/ \\
\hline & Density of local roads (m/ha) & ftp://ftp2.census.gov/geo/tiger/TIGER2009/ \\
\hline & Density of highways (m/ha) & ftp://ftp2.census.gov/geo/tiger/TIGER2009/ \\
\hline & Distance to local roads (m) & ftp://ftp2.census.gov/geo/tiger/TIGER2009/ \\
\hline \multirow{5}{*}{ Hydrology } & Density of wells (number of wells/ha) & http://nris.mt.gov/nsdi/nris/shape/gwicwells.zip \\
\hline & Distance to wells (m) & http://nris.mt.gov/nsdi/nris/shape/gwicwells.zip \\
\hline & Density of canals or ditches (m/ha) & http://nris.state.mt.us/nsdi/nhd/hiresgeo.asp \\
\hline & Distance to canals or ditches (m) & http://nris.state.mt.us/nsdi/nhd/hiresgeo.asp \\
\hline & $\begin{array}{l}\text { Density of Water Rights (number of water } \\
\text { rights/ha) }\end{array}$ & http://maps2.nris.mt.gov/mapper/ \\
\hline \multirow{12}{*}{ Land Use } & Percent of envelope in cultivated cropland & ftp://nris.mt.gov/MSDI_Landcover.zip \\
\hline & Percent of envelope in hay/pasture & ftp://nris.mt.gov/MSDI_Landcover.zip \\
\hline & Percent of envelope in developed, open space & ftp://nris.mt.gov/MSDI_Landcover.zip \\
\hline & Percent of envelope in low density residential & ftp://nris.mt.gov/MSDI_Landcover.zip \\
\hline & $\begin{array}{l}\text { Percent of envelope in medium density } \\
\text { residential }\end{array}$ & ftp://nris.mt.gov/MSDI_Landcover.zip \\
\hline & $\begin{array}{l}\text { Percent of envelope in quarries, mines, or } \\
\text { gravel pits }\end{array}$ & ftp://nris.mt.gov/MSDI_Landcover.zip \\
\hline & Percent of envelope that is continuously & http://nris.mt.gov/nsdi/nris/mdb/revenue_flu.zip \\
\hline & cropped & \\
\hline & Percent of envelope that is non-irrigated & http://nris.mt.gov/nsdi/nris/mdb/revenue_flu.zip \\
\hline & hay land & \\
\hline & Percent of envelope that is irrigated land & http://nris.mt.gov/nsdi/nris/mdb/revenue_flu.zip \\
\hline & $\begin{array}{l}\text { Percent of envelope that is summer fallow } \\
\text { farmland }\end{array}$ & http://nris.mt.gov/nsdi/nris/mdb/revenue_flu.zip \\
\hline \multirow{3}{*}{$\begin{array}{l}\text { Wetland } \\
\text { characteristics }\end{array}$} & Wetland polygon size (ac) & http://nris.mt.gov/nsdi/nris/shape/nwi_poly.zip \\
\hline & $\begin{array}{l}\text { Perimeter to area ratio of wetland polygon } \\
\left(\mathrm{m} / \mathrm{m}^{2}\right)\end{array}$ & http://nris.mt.gov/nsdi/nris/shape/nwi_poly.zip \\
\hline & Distance to nearest five wetlands (m) & http://nris.mt.gov/nsdi/nris/shape/nwi_poly.zip \\
\hline
\end{tabular}

Once at the target sample point, field team members determined the extent of the AA by estimating the approximate boundaries of the wetland within the potential AA. Readily observable ecological criteria such as vegetation, soil, and hydrological characteristics were used to define wetland boundaries, regardless of whether they met jurisdictional criteria for wetlands regulated under the Clean Water Act. Because certain field metrics vary by Ecological System, every attempt was made to include a single Ecological System in the AA. If the target sample point occurred at the edge of a wetland or at the edge of one Ecological System type, then field teams adjusted the point up to $60 \mathrm{~m}$.

The EIA form also contains a list of observed stressors or disturbances that are commonly 
found in the Rocky Mountains (Table 7). Stressor lists can provide additional information when evaluating ecological integrity and aid in further understanding of overall wetland condition. In some cases, stressors may be present at or near a site, but condition metrics may not reflect these impacts. This may be caused by a temporal lag between the impact and its effect on the biotic community, such as a very recent clear cut. Or it may reflect stressors the current biotic metrics do not pick up. In the first case, the stressor list can be used to flag sites that may become degraded in the future. In the second case, the stressor list may indicate adjustments should be made to the metrics.
Along with recording the occurrence of a stressor, the scope and severity of each stressor were also estimated (Faber-Langendoen et al. 2011; Table 8). Scope is defined as the proportion of the occurrence of an ecosystem that can reasonably be expected to be affected by the stress. Severity is the level of damage to the site from the stressor that can reasonably be expected with continuation of current circumstances. Stressor scope and severity scores are rolled up into an overall stressor impact score (Appendix D).

In addition to the EIA indicator metrics and observed stressors, we also collected standard site

Table 7. Stressor metrics and associated disturbance categories.

\begin{tabular}{ll}
\hline Transportation Disturbances & Land Use Disturbances-Vegetation Removal \\
\hline Paved surfaces (e.g., roads, parking lots) & Chemical vegetation control \\
Unpaved roads & Evidence of intentional burning \\
Railroads & Vegetation conversion \\
\hline Land Use Disturbances-Development or Recreation & Natural or Environmental Disturbances \\
\hline Domestic or commercial development & Beetle-killed Pinus species \\
Intensively managed sports fields, golf courses & Other diseased conifers \\
Recreation or human visitation & Evidence of recent fire ( $<5$ years) \\
Filling or dumping of sediment or fill & Beaver activity \\
Trash or refuse dumping & Evidence of prolonged drought \\
& Browsing of woody vegetation by native ungulates \\
\hline Hydrologic Disturbances & Land Use Disturbances-Agriculture \\
\hline Upstream spring box & Dryland farming \\
Impoundment of flowing water & Livestock grazing \\
Potential for agricultural runoff & Irrigated cropland \\
Potential for urban runoff & Irrigated hay pasture \\
Upstream dam & Permanent tree plantation \\
Reservoir/stock pond & Disturbed fallow lands dominated by exotic species \\
Weir or drop structure & Haying of native grassland \\
Dredged inlet/outlet channel & Fallow fields (no human use in past 10 years) \\
Engineered channel (e.g., riprap) & Plowing or discing \\
\cline { 2 - 2 } Pumps, diversions, or ditches that move water into wetland & Land Use Disturbances-Resource Extraction \\
\cline { 2 - 2 } Pumps, diversions, or ditches that move water out of & Gravel pits, open pit mining \\
wetland & Other mining activity or abandoned mines \\
Berms/Dikes/Levees & Resource extraction (oil and gas) \\
& Intensive logging ( $50-75 \%$ trees of $>50$ cm diameter \\
removed) \\
\hline & Selective logging ( $<50 \%$ of trees $>50$ cm diameter \\
removed)
\end{tabular}


Table 8. Scope and severity ratings for stressors observed within the assessment area (AA) and within a 200-m envelope around the $A$ A.

\begin{tabular}{cl}
\hline Scope of Disturbances \\
\hline 5 & Pervasive - Affects nearly all $(>75 \%)$ of the buffer or AA. \\
4 & Large - Affects most $(>50-75 \%)$ of the buffer or AA. \\
3 & Moderate - Affects much $(>25-50 \%)$ of the buffer or AA. \\
2 & Restricted - Affects some $(>10-25 \%)$ of the buffer or AA. \\
1 & Small - Affects a small $(1-10 \%)$ portion of the buffer or AA. \\
0 & Nil - Little or no observed effect $(<1 \%)$ on the buffer or AA. \\
\hline Severity of Disturbances \\
\hline 4 & Extreme - likely to extremely modify, degrade, destroy, or eliminate the wetland. \\
2 & Serious - likely to seriously modify, degrade or reduce wetland function or condition. \\
1 & Moderate - likely to moderately modify, degrade or reduce wetland function or condition. \\
\hline
\end{tabular}

variables at each sample location. These included:

- UTM coordinates

- $\quad$ Elevation, slope, and aspect

- Ecological System classification (Comer et al. 2003)

- $\quad$ Dominant plant species

- HGM classification (Hauer et al. 2002)

- Cowardin classification (Cowardin et al. 1979)

- Nearby landforms (alluvial fans, narrow bedrock valley, alluvial valley, etc.)

- Description of onsite and adjacent ecological processes and land use

- $\quad$ Description of general site characteristics and a site drawing

- Selected soils data: depth and identification of soil horizons, texture, and color

- Water table depth

At least four photos were taken from the AA center at each site (Figure 7). Photos were taken $90^{\circ}$ from each other, and the aspect was recorded to the nearest $5^{\circ}$ at all photo points. Photo placards were placed in the corner of each photo. Additional photos were taken as needed to document the wetland and surrounding landscape.

At each sampling location, we collected detailed soil data by excavating a soil pit $45-60 \mathrm{~cm}$ in depth. For each horizon, we recorded depth, soil layers, matrix color, redoximorphic feature color and abundance (\%), and soil texture. Soil color was determined using Munsell Soil Color Charts (Munsell Color Company 2000).

\section{Level 3 Intensive Assessments}

Field methods for Level 3 assessments are detailed in the Montana Ecological Integrity Assessment Field Manual (MTNHP 2010b). We collected intensive Level 3 vegetation data at approximately $30 \%$ of sites using a $20 \mathrm{~m} \times 50 \mathrm{~m}$ relevé plot (Peet et al. 1998). This method takes up to six

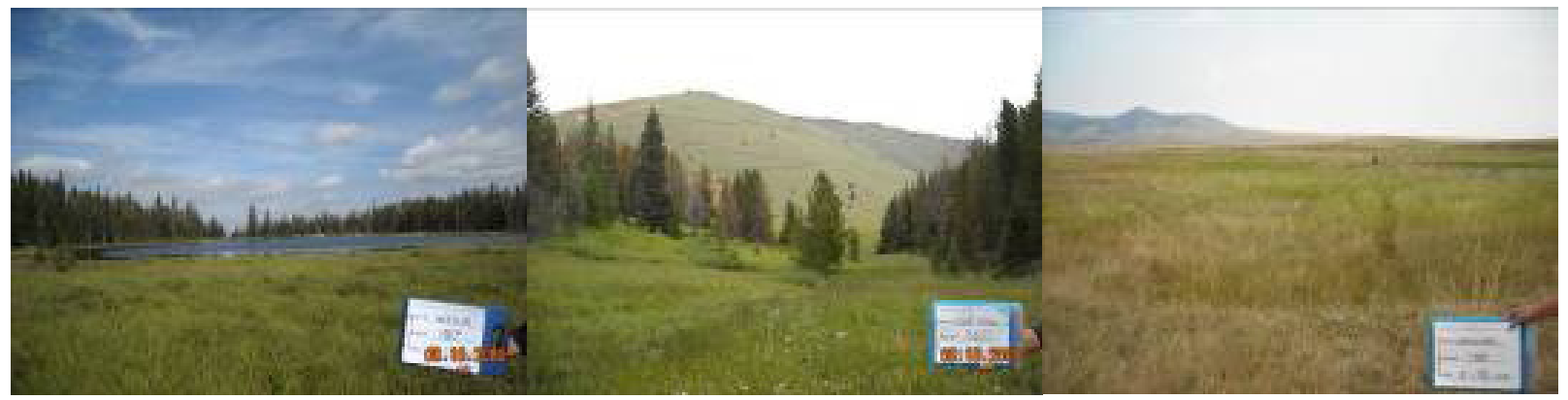

Figure 7. Example plot photos from wetland condition assessments in Montana. 
hours per site. The method has been in use by the North Carolina Vegetation Survey for over 10 years (Peet et al. 1998) and has been used to successfully develop a vegetation index of biotic integrity (VIBI) in Ohio (Mack 2004) and Colorado (Rocchio 2006; Rocchio 2007; Lemly and Rocchio 2009). The structure of the plot consists of $1010 \mathrm{~m}$ $\mathrm{x} 10 \mathrm{~m}\left(100 \mathrm{~m}^{2}\right)$ modules typically arranged in a 2 $\mathrm{m} \times 5 \mathrm{~m}$ array (Figure 8). The plot was subjectively placed within the AA to maximize abiotic/biotic heterogeneity. Capturing heterogeneity within the plot ensures adequate representation of local variations produced by hummocks, water tracks, side-channels, pools, wetland edge, microtopography, etc.

The following guidelines were used to determine plot locations within the AA:

- The plot was located in a representative area of the AA that incorporates as much microtopographic variation as possible.

- If the AA was homogeneous and there was no direction or orientation evident in the vegetation, the plot was laid out to run either N-S or E-W using the second hand on a watch to randomly determine direction $(00-29 \mathrm{sec}=\mathrm{N}-\mathrm{S}$ orientation; 30-59 sec $=$ E-W orientation).

- If the AA was not homogeneous, was oddly shaped, or was directional (i.e., followed a stream), the plot was oriented to adequately represent all wetland features.

- If the wetland had an irregular shape and the $20 \mathrm{~m} \times 50 \mathrm{~m}$ plot did not "fit" within the AA, the $2 \mathrm{~m} \times 5 \mathrm{~m}$ array of modules was restructured to accommodate the shape of the AA. For example, a $1 \mathrm{~m}$ x $5 \mathrm{~m}$ array of $100 \mathrm{~m}^{2}$ modules was used for narrow, linear areas and a $2 \mathrm{~m} \times 2 \mathrm{~m}$ array of $100 \mathrm{~m}^{2}$ modules was used for small, circular sites.

- The plot captured the range of diversity within the AA, without crossing over into the upland. No more than $20 \%$ of the plot was located in upland areas beyond the wetland. If end modules crossed into the upland, they were not sampled as intensive modules.

- If a small patch of another wetland type was present in the AA (but not large enough to be delineated as a separate Ecological System), the plot was placed so at least a portion of the patch was in the plot.

- $\quad$ Localized, small areas of human-induced disturbance were included in the plot according to their relative representation of the AA.

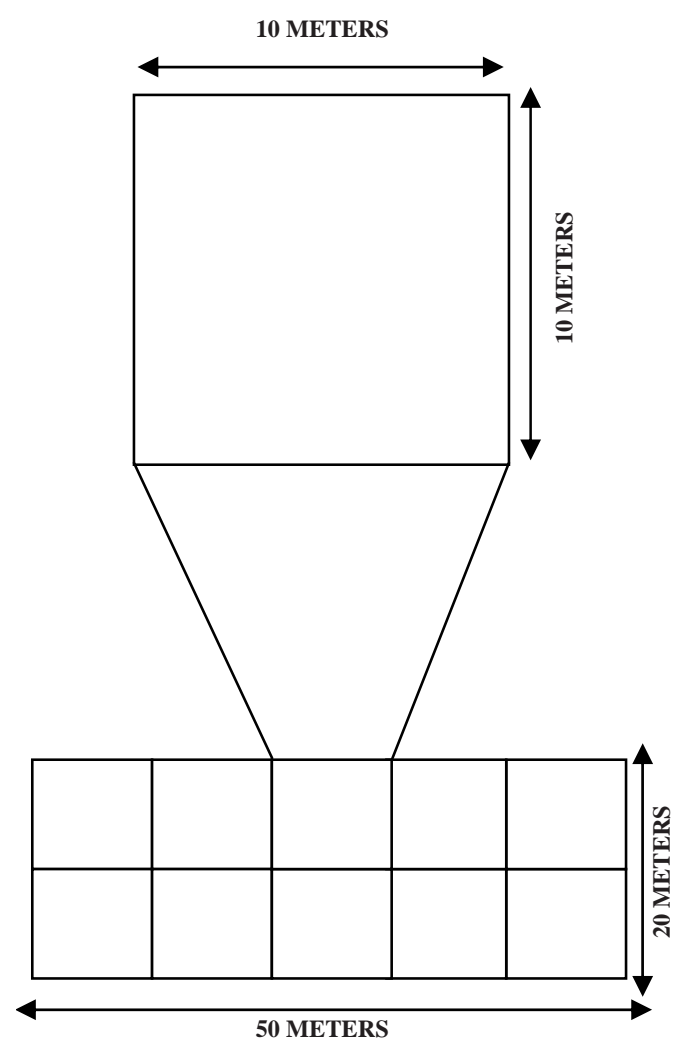

Figure 8. Reléve plot layout (adapted from Peet et al. 1998).

Absolute cover of all vascular species was estimated within four of the $100 \mathrm{~m}^{2}$ modules, referred to as "intensive" modules. Additionally, a complete species list was made within each intensive module. When all species within a module had been identified, cover was visually estimated for the $100 \mathrm{~m}^{2}$ module using the following cover classes (Peet et al. 1998):

$$
\begin{aligned}
& 1=\text { trace (one individual) } \\
& 2<1 \% \\
& 3 \geq 1-2 \% \\
& 4 \geq 2-5 \%
\end{aligned}
$$




$$
\begin{aligned}
& 5 \geq 5-10 \% \\
& 6 \geq 10-25 \% \\
& 7 \geq 25-50 \% \\
& 8 \geq 50-75 \% \\
& 9 \geq 75-95 \% \\
& 10 \geq 95 \%
\end{aligned}
$$

After sampling each of the intensive modules, the remaining, or residual, modules were walked to document presence of any species not recorded in the intensive modules. Percent cover of these species was estimated over the entire $1,000 \mathrm{~m}^{2}$ plot.

In the field, vascular plants were identified using the Vascular Plants of Montana (Dorn 1984) as well as ancillary dichotomous keys specific to certain plant genera (e.g., carices). The statebased nomenclature was crosswalked to nationally accepted nomenclature based on the USDA PLANTS Database (http://plants.usda.gov).

\section{Intensive Assessment of Stressors}

To capture the actual spatial extent of stressors observed within the 200-m envelope around the AA perimeter, we estimated the percent of the 200$m$ envelope affected by each stressor. For linear features such as roads, we estimated the length in meters of each stressor within the 200-m envelope.

\section{Data Management}

We created a relational database in Microsoft Access ${ }^{\circledR}$. All EIA data and vegetation plot data were entered into the database at the completion of the field season. For vegetation data, plant species mean cover values were averaged across modules to get an average cover value for each plant species for the entire vegetation plot. Unknown species or ambiguous species (e.g., Carex sp.) were entered into database, but these were not included in data analysis.

\section{Data Analysis \\ Level 1 Assessments}

We calculated descriptive statistics for and assessed the range and distribution of each metric by examining frequency histograms. We created correlation matrices using Spearman's correlation coefficients to investigate relationships and evaluate redundancy among metrics.

\section{Level 2 Assessments}

Scores were calculated for each site using metric narrative ratings and scoring formulas (Appendix E). A score was calculated for the site overall as well as separately for each major attribute.

We calculated descriptive statistics for and assessed the range and distribution of each metric by examining frequency histograms. We created correlation matrices using Spearman's correlation coefficients to investigate relationships and to evaluate any redundancy among metrics. Similarly, we calculated Spearman's correlation coefficients of attribute scores and final wetland condition scores to determine the amount of variability explained by each attribute and each metric.

\section{Level 3 Vegetation Assessments}

We calculated multiple vegetation metrics (Appendix F) to conduct a floristic quality assessment (FQA). The FQA accounts for the presence of both native and exotic species, as well as individual plant species' tolerance of and sensitivity to disturbance (Cronk and Fennessy 2001, Miller and Wardrop 2006). Coefficients of conservatism (C-values) are assigned to taxa identified to species and represent the relative tolerance of a species to disturbance, ranging from 0 to 10 (after Andreas et al. 2004). Native species that exhibit high degrees of ecological specificity and sensitivity to disturbance have Cvalues of 9-10. Native species that are typical of well-established communities that have undergone minimal disturbance have C-values of 6-8. Native species that have some degree of habitat specificity but can tolerate moderate disturbance have Cvalues of 3-5. Widespread native species that occur in a variety of communities and are common in disturbed sites have values of 1-2. Finally, exotic species were assigned C-values of 0 .

We calculated descriptive statistics for and assessed the range and distribution of vegetation metrics by examining frequency histograms. We created correlation matrices using Spearman's correlation 
coefficients to investigate relationships and to evaluate any redundancy among metrics. We also used Spearman's correlation coefficients to evaluate the relationship of metrics to observed stressors as well as the ability of metrics to discriminate among wetland sites of varying condition. 


\section{Results}

\section{Wetland Landscape Profile}

Based on digital mapping, wetlands and other waterbodies within the project area totaled 228,992 ac $(92,670$ ha). Note this total includes deepwater areas such as lakes and river channels, which provide critical aquatic habitat and other valuable ecosystem services but are not considered wetlands. By system, the majority (82\%) of the mapped acres are palustrine, or freshwater, wetlands (Figure 9). By class, freshwater emergent wetlands make up the majority (63\%) of wetland acres (Figure 10). By water regime, temporarily and seasonally flooded wetlands are the most common (Figure 11). These wetlands typically have surface water a few days or weeks during the growing season but dry down later in the season. Only $5 \%$ of wetlands have wetter regimes, such as semipermanently flooded and intermittently exposed. The permanently flooded regime is used only for lakes and rivers. By hydrogeomorphic class, riverine wetlands make up the largest proportion of wetlands, followed by depressional wetlands (Figure 12).

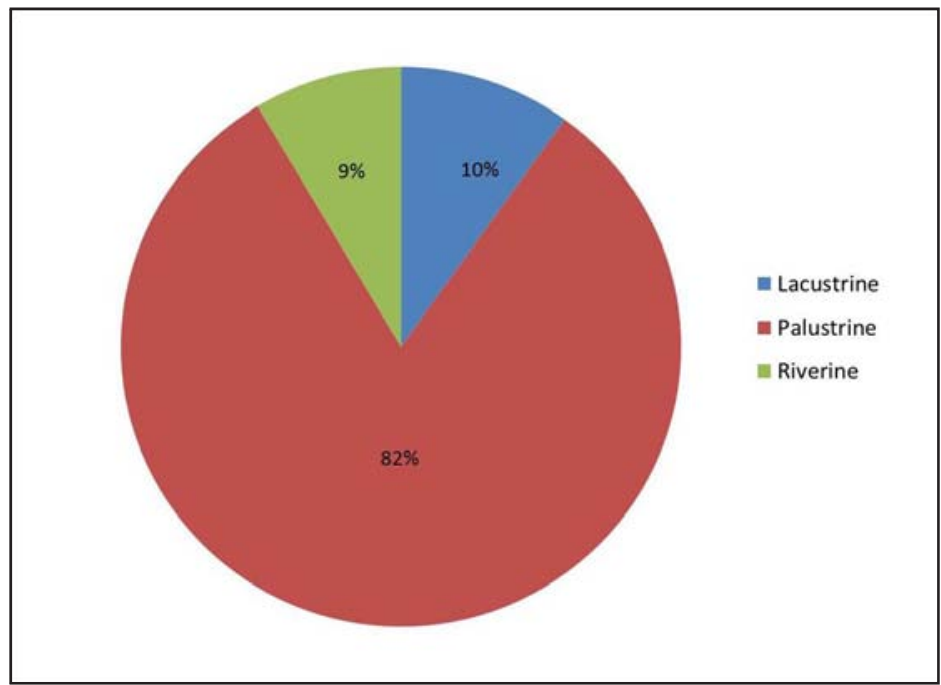

Figure 9. Percent of mapped wetland acres by Cowardin system in the southwest Montana basin-wide assessment project area.

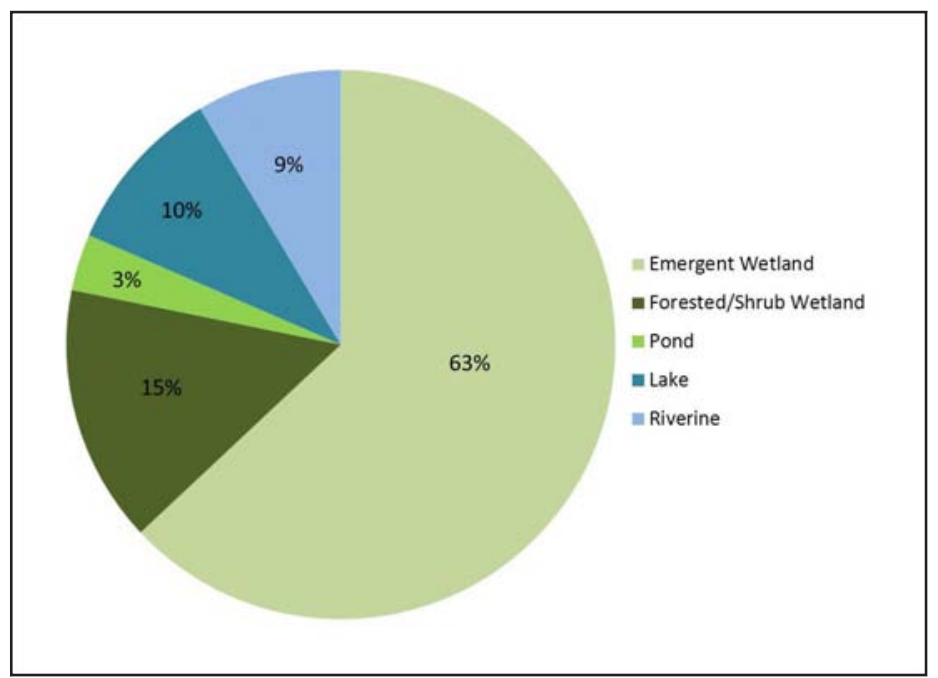

Figure 10. Percent of mapped wetland acres by Cowardin class in the southwest Montana basin-wide assessment project area. 


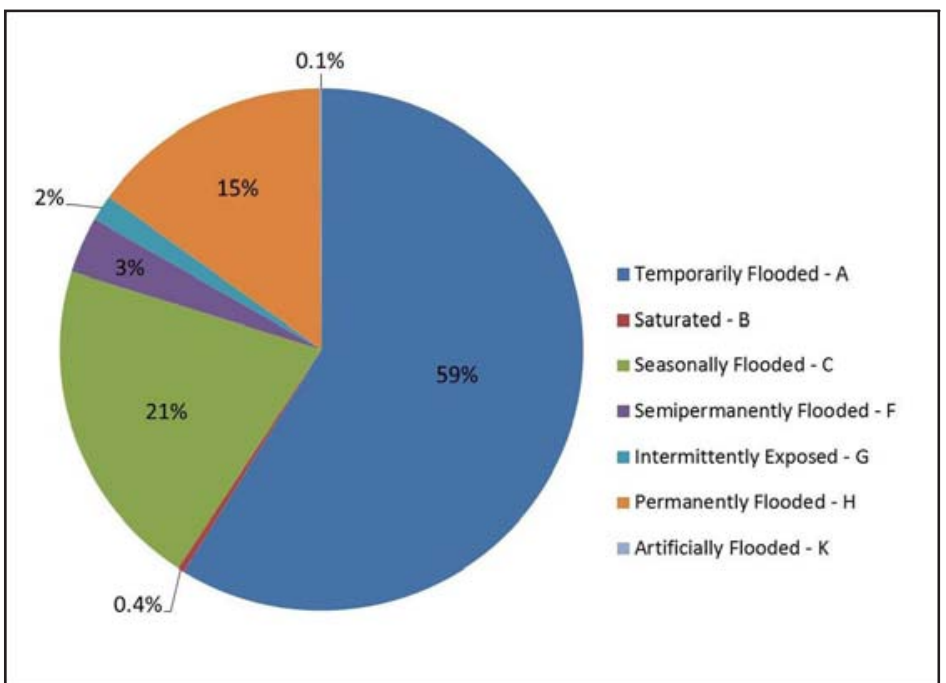

Figure 11. Percent of mapped wetland acres by Cowardin water regime in the southwest Montana basin-wide assessment project area.

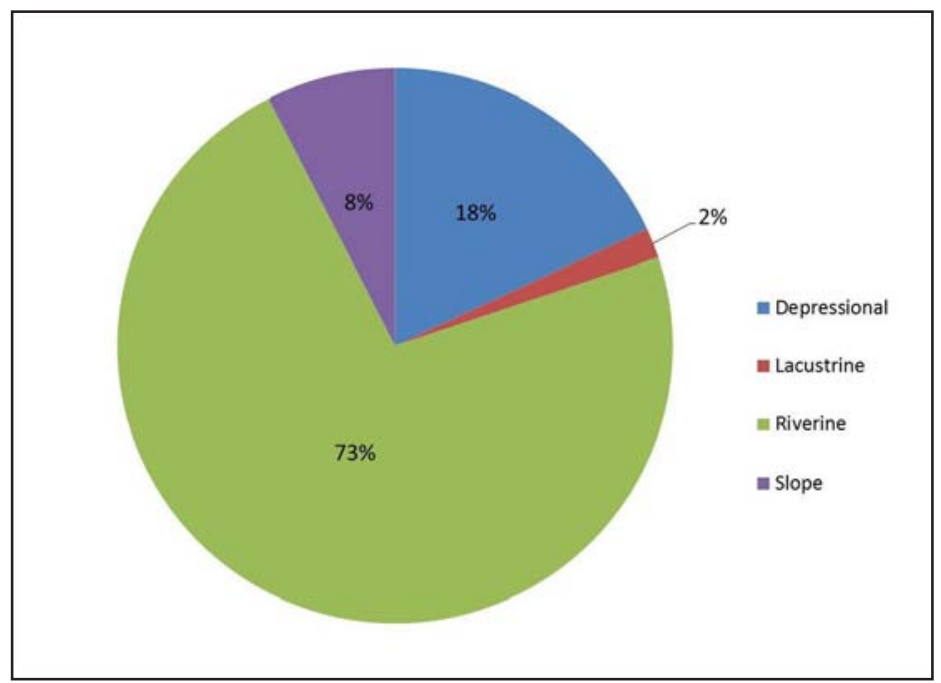

Figure 12. Percent of mapped wetland acres by hydrogeomorphic (HGM) system in the southwest Montana basin-wide assessment project area.

Most anthropogenically altered wetlands in the project area fall into the Lacustrine System, as these mapped wetland types represent large reservoirs created by stream impoundments (Figure 13). Altered riverine wetlands represent excavated canals and ditches. Just over 3\% of palustrine wetlands in the project area are anthropogenically altered. The spatial distribution of palustrine wetlands by watershed is included in Appendix G.

Wetlands with the potential for high functional performance of water storage and groundwater recharge functions had the highest proportion in the project area, each making up 36\% of the project area. Sediment retention and terrestrial habitat functions make up the next highest proportion of the project area, at $21.5 \%$ and $16.7 \%$, respectively.

\section{Level 1 Landscape \\ Characterization}

When considered at the individual wetland polygon, the density of local roads (unpaved and rural roads) was two m/ha. Road density was over four times higher $(9.5 \mathrm{~m} / \mathrm{ha})$ when considered at the next spatial scale of the 100-m envelope around 


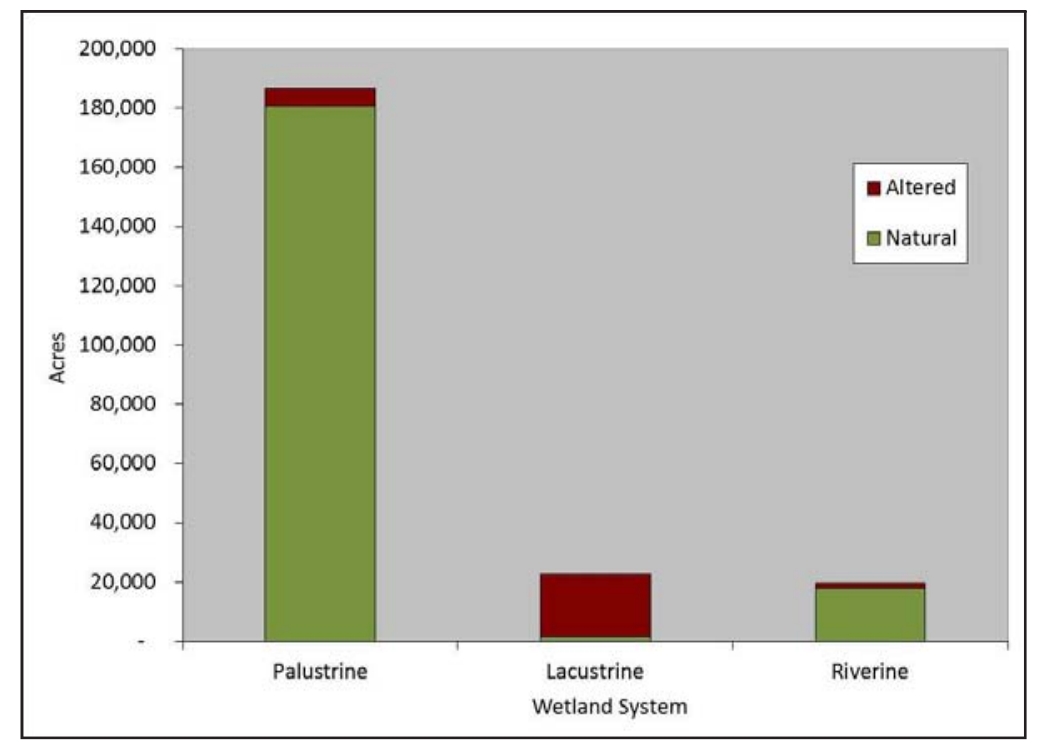

Figure 13. Proportion of mapped wetlands classified as anthropogenically altered in the southwest Montana basin-wide assessment project area.

the wetland polygon. Land uses at all spatial scales were primarily agricultural. At the wetland polygon scale, cultivated cropland and irrigated lands comprised about 3\% of the land area. At the scale of the 1,000-m envelope, this value increased to about $9 \%$. The density of canals decreased with increasing distance from the wetland polygon. At the scale of the wetland polygon, canal density was $6.7 \mathrm{~m} / \mathrm{ha}$ and decreased to $2.5 \mathrm{~m} / \mathrm{ha}$ at the $1,000-\mathrm{m}$ scale. The density of both water rights and wells were essentially absent at all spatial scales. The mean distance of selected wetland polygons to local roads was $732 \mathrm{~m}$. The mean distance of wetland polygons to canals or wells was 5,200-m and 2,100 m, respectively.

The average distance of selected wetland polygons to the nearest five wetland polygons was $236 \mathrm{~m}$. The average perimeter area ratio of selected palustrine wetlands was $0.16 \mathrm{~m} / \mathrm{m}^{2}$, and the average mapped polygon size was 2.68 ac.

Summary statistics for selected wetland polygons for the entire project area and for each individual watershed are included in Appendix H.

Results of the LIM indicate anthropogenic disturbances, such as road and urban and agricultural development, were isolated mostly to valley bottoms (Figure 14).

\section{Level 2 Assessments}

We visited 100 wetlands during the summer of 2010. Of these, seven wetlands did not meet the criteria for further assessment, so 93 wetlands were sampled using the MTNHP EIA protocol. The majority of sampled sites (72\%) were located on lands owned by the U.S. Forest Service (Figure 15). Sampled wetlands represent several Ecological Systems (Table 9). Wet meadow sites were the most common wetland system sampled (Figure 16). Wet meadow sites in the project area were dominated by sedge (Carex) species, including water sedge (C. aquatilis), Northwest Territory sedge (C. utriculata), Nebraska sedge (C. nebrascensis), and clustered field sedge (C. praegracilis). Other common graminoids included tufted hairgrass (Deschampsia cespitosa), bluejoint (Calamagrostis canadensis), northern reedgrass $(C$. stricta), and non-native pasture grasses, particularly Kentucky bluegrass (Poa pratensis), meadow foxtail (Alopecurus pratensis), and common timothy (Phleum pratense). Mountain rush (Juncus arcticus) was the most commonly encountered rush species, tending to increase in areas grazed by livestock. A variety of forbs were common, depending upon the length of the hydroperiod. These included wild chives (Allium schoenoprasum), elephanthead lousewort (Pedicularis groenlandica), scentbottle (Platanthera dilatata), arrowleaf ragwort (Senecio 


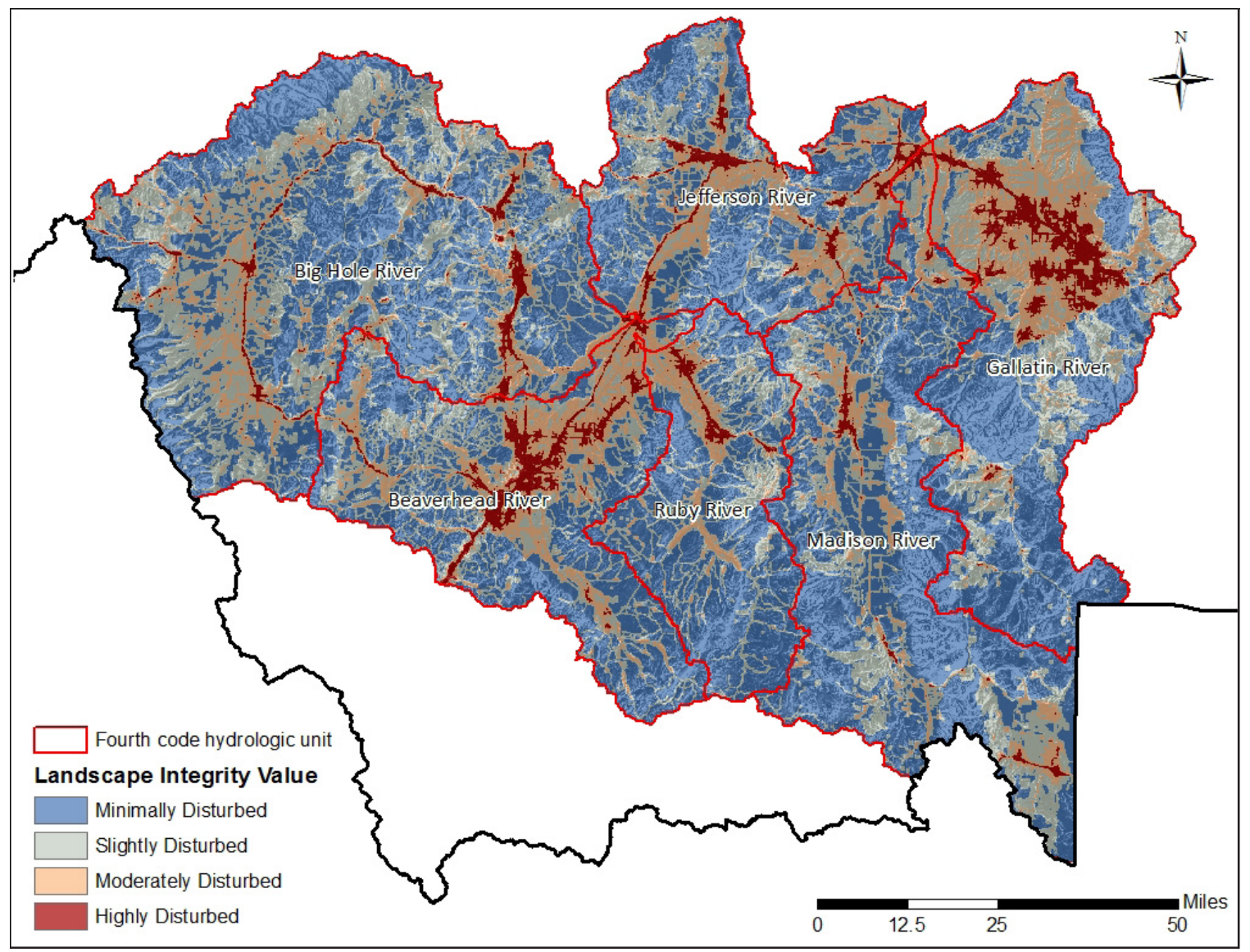

Figure 14. Landscape integrity classes for the southwest Montana basin-wide assessment project area.

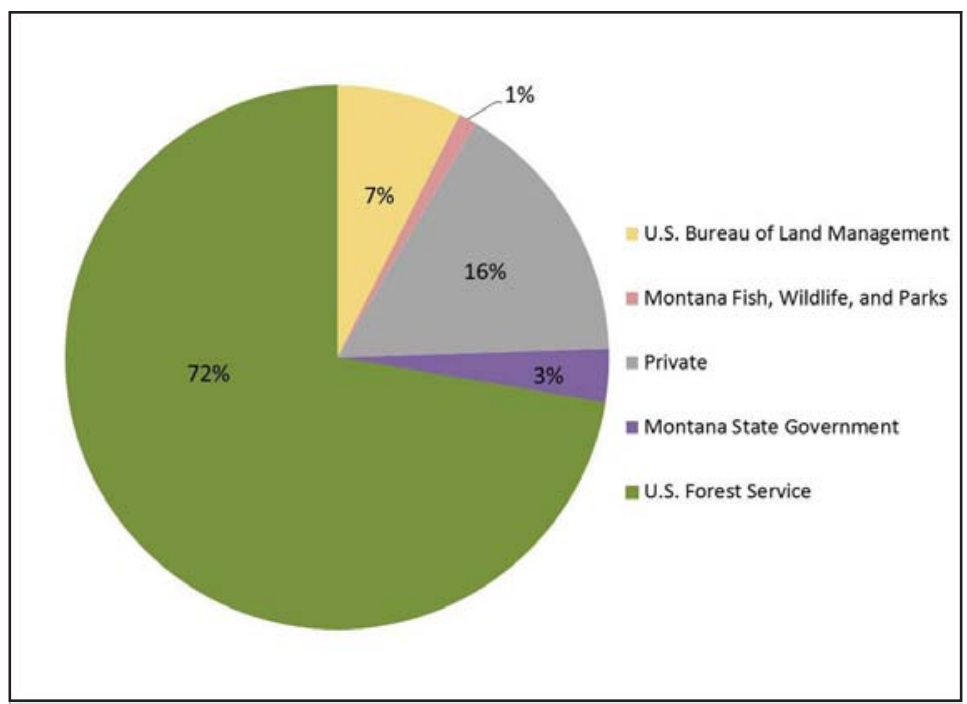

Figure 15. Sampled wetlands by land ownership in the southwest Montana basin-wide assessment project area. 
Table 9. Sampled wetlands by Ecological System in the southwest Montana basin-wide assessment project area.

\begin{tabular}{lc}
\hline Ecological System & $\begin{array}{c}\text { Number of Sites } \\
\text { Sampled }\end{array}$ \\
\hline Northern Rocky Mountain Wooded Vernal Pool & 1 \\
Rocky Mountain Alpine-Montane Wet Meadow & 40 \\
Rocky Mountain Subalpine-Montane Fen & 7 \\
Rocky Mountain Subalpine-Montane Riparian Shrubland & 16 \\
Western North American Emergent Marsh & 29 \\
\hline
\end{tabular}

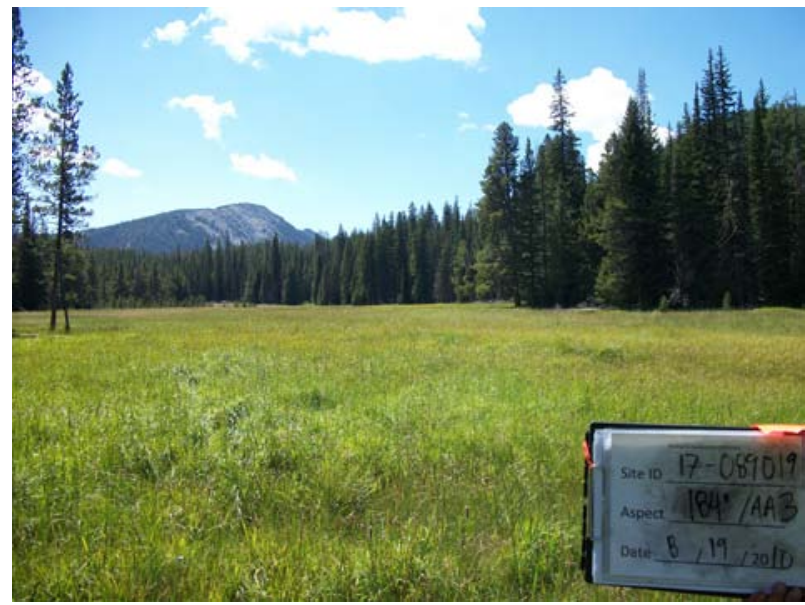

Figure 16. Rocky Mountain Alpine-Montane Wet Meadow site sampled as part of the southwest Montana basin-wide assessment project.

triangularis), slender cinquefoil (Potentilla gracilis), and meadow thistle (Cirsium scariosum). Rocky Mountain iris (Iris missouriensis) increased in dominance with increasing livestock grazing. These wet meadows occasionally had low to moderate cover of shrubby cinquefoil (Dasiphora fruticosa).

Emergent marsh was the second most sampled wetland system (Figure 17). Marshes had similar species composition to wet meadows; however, these wetlands typically had lower species diversity, tending to be dominated by graminoids, particularly sedges. Marshes also had a higher proportion of wetland obligates such as $C$. utriculata and common cattail (Typha latifolia).

Riparian shrubland sites were the third most sampled system (Figure 18). These wetlands were dominated by various willow (Salix) species, particularly Booth's willow (S. boothii), Geyer willow (S. geyeriana), and Drummond's willow
(S. drummondiana). Redosier dogwood (Cornus sericea), gooseberry (Ribes spp.), and Wood's rose (Rosa woodsii) were also commonly occurring woody species.

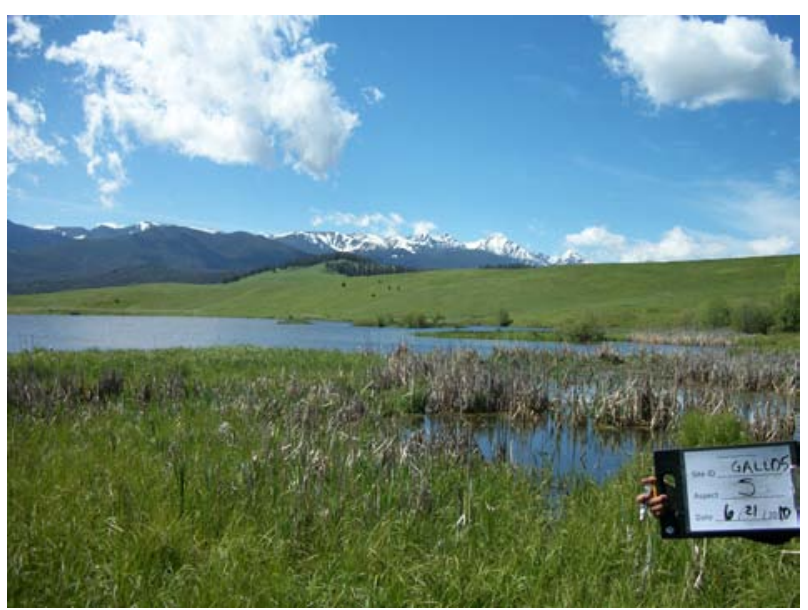

Figure 17. Western North American Emergent Marsh site sampled as part of the southwest Montana basin-wide assessment project.

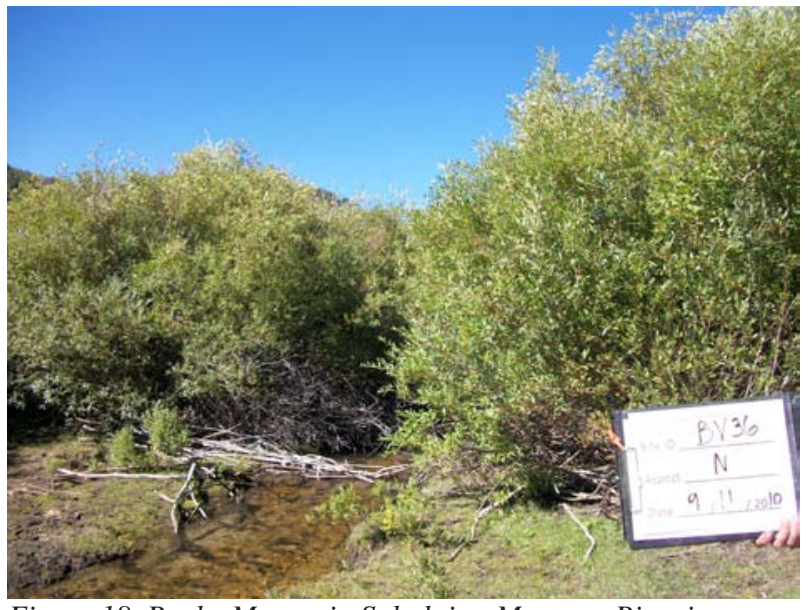

Figure 18. Rocky Mountain Subalpine-Montane Riparian Shrubland site sampled as part of the southwest Montana basin-wide assessment project. 
The seven fen wetland sites (Figure 19 and 20) were largely sedge dominated, with $C$. aquatilis and C. utriculata being most common. Calamagrostis canadensis was a commonly occurring graminoid. Marsh marigold (Caltha leptosepala), western Labrador tea (Ledum glandulosum), western false asphodel (Triantha occidentalis), and alpine laurel (Kalmia microphylla) were commonly encountered forbs.

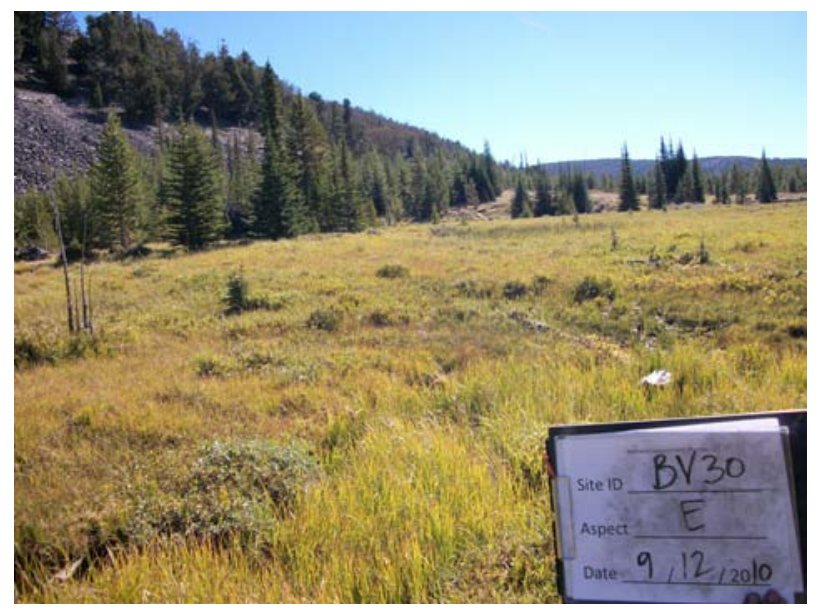

Figure 19. A slope Rocky Mountain Subalpine-Montane Fen site sampled as part of the southwest Montana basin-wide assessment project.

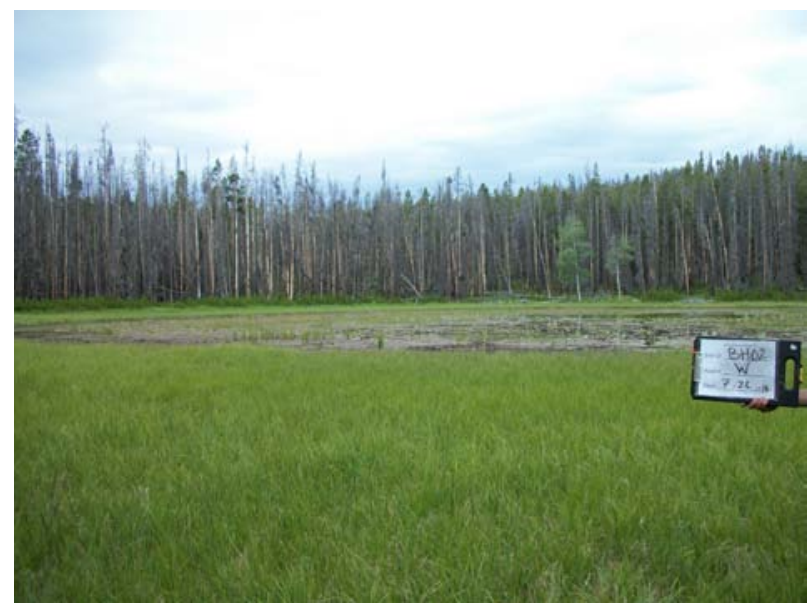

Figure 20. A basin Rocky Mountain Subalpine-Montane Fen site sampled as part of the southwest Montana basin-wide assessment project.

We sampled one example of a Northern Rocky Mountain Wooded Vernal Pool. This site was a shallow pond ringed with aspen (Populus tremuloides), Douglas-fir, and Engelmann's spruce.
Wetlands sampled were also classified by hydrogeomorphic (HGM) system in the field. The majority of wetlands sampled were classified as slope wetlands, in which groundwater was the primary hydrologic input (Table 10).

Level 2 condition scores were calculated for all 93 wetlands sampled. Scores ranged from 55-100 out of a possible range of 21.5-100 (Figure 21). We divided our assessment scores into four categories defined relative to their departure from reference standard: at or near expected reference standard ( scores $=90-100)$; slight departure from expected reference standard (scores $=80-89$ ); moderate departure from expected reference standard (scores =70-79); and severe departure from expected reference standard (scores $<70$ ). Wet meadow, emergent marshe, and riparian shrubland sites had scores across the range of condition categories, indicating they may be impacted by a range of stressors (Table 11). Fens were either near reference standard or at a severe departure from reference standard.

The condition scores for each of the four attributes that comprise the overall condition score, Landscape Context, Vegetation, Physicochemical, and Hydrologic attributes, showed variable patterns (Table 12). Landscape Context attribute scores ranged across condition categories for wet meadow, riparian shrubland, and emergent marshe sites.

Most wet meadow and emergent marsh sites were ranked as Near Reference or a Slight Departure from Reference, indicating most of these sites were surrounded by wide, intact buffers. The scores for riparian shrublands were fairly evenly spread across condition categories, reflecting the variety of landscapes in which these sites occurred. All but one fen site were ranked at or near reference standard. These sites were typically in remote areas on public lands.

Physicochemical scores for most sites were within the top two condition categories, although emergent marshes showed a relatively even spread across condition categories. This was largely due to the reduced soil surface integrity and poor water quality indicators (e.g., algae). Hydrologic attribute scores were consistently high across ecological 
Table 10. Sampled wetlands by hydrogeomorphic system in the southwest Montana basin-wide assessment project area.

\begin{tabular}{lc}
\hline Hydrogeomorphic System & Number of Sites Sampled \\
\hline Depressional & 11 \\
Lacustrine Fringe & 4 \\
Riverine & 14 \\
Slope & 64 \\
\hline
\end{tabular}

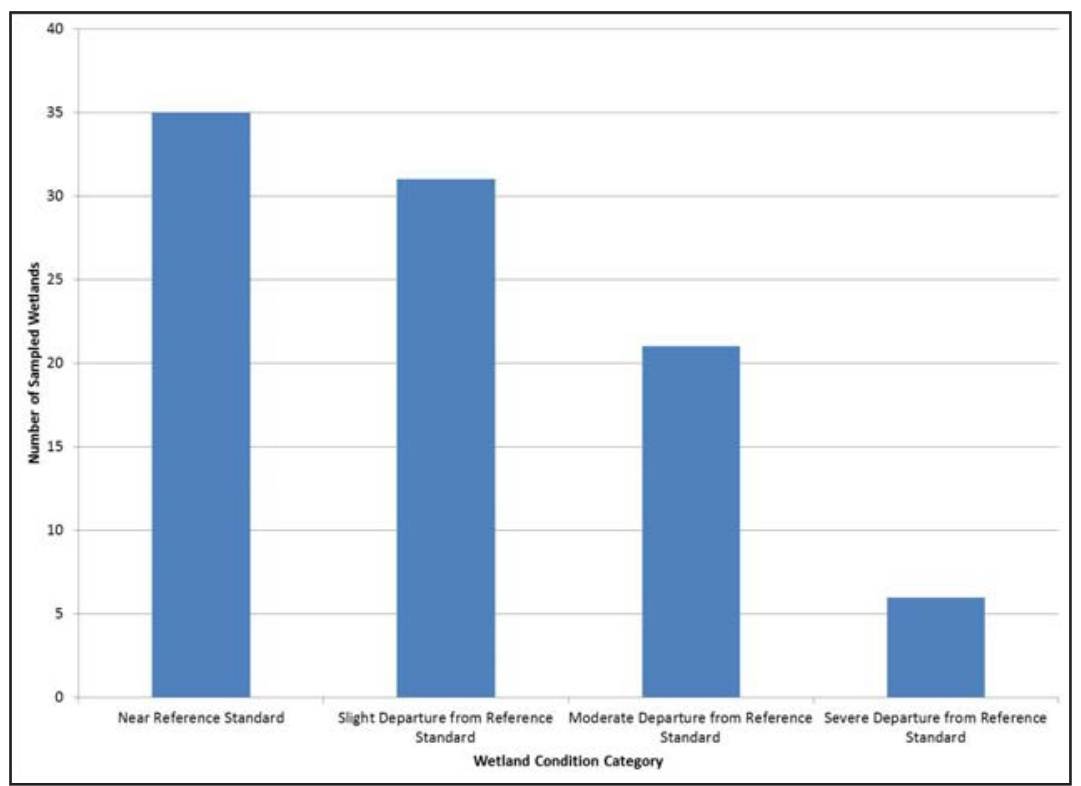

Figure 21. Level 2 assessment condition categories for wetlands assessed as part of the southwest Montana basin-wide assessment.

Table 11. Wetland condition category indicating the departure from expected reference standard by wetland ecological system for the southwest Montana basin-wide assessment project area. Condition categories are interpreted as: at or near reference standard; slight departure from reference standard; moderate departure from reference standard; and severe departure from reference standard.

\begin{tabular}{lcccc}
\hline & \multicolumn{3}{c}{ Condition Category } \\
\cline { 2 - 4 } Ecological System & Near Reference & Slight & Moderate & Severe \\
\hline Northern Rocky Mountain Wooded Vernal Pool & 16 & 14 & 1 & \\
Rocky Mountain Alpine-Montane Wet Meadow & 6 & & & 2 \\
Rocky Mountain Subalpine-Montane Fen & 6 & 4 & 5 & 1 \\
Rocky Mountain Subalpine-Montane Riparian Shrubland & 10 & 11 & 8 & \\
Western North American Emergent Marsh & & & \\
\hline
\end{tabular}


Table 12. EIA attribute condition category indicating the departure from expected reference standard by wetland ecological system for the southwest Montana basin-wide assessment project area. Condition categories are interpreted as: at or near reference standard; slight departure from reference standard; moderate departure from reference standard; and severe departure from reference standard.

\begin{tabular}{|c|c|c|c|c|}
\hline & \multicolumn{4}{|c|}{ Condition Category } \\
\hline & $\begin{array}{c}\text { Near } \\
\text { Reference }\end{array}$ & Slight & Moderate & Severe \\
\hline \multicolumn{5}{|l|}{ Landscape Context Attribute } \\
\hline Northern Rocky Mountain Wooded Vernal Pool & & & & 1 \\
\hline Rocky Mountain Alpine-Montane Wet Meadow & 21 & 5 & 8 & 6 \\
\hline Rocky Mountain Subalpine-Montane Fen & 6 & & & 1 \\
\hline Rocky Mountain Subalpine-Montane Riparian Shrubland & 6 & 2 & 3 & 5 \\
\hline Western North American Emergent Marsh & 17 & 1 & 5 & 6 \\
\hline \multicolumn{5}{|l|}{ Vegetation Attribute } \\
\hline Northern Rocky Mountain Wooded Vernal Pool & & & & 1 \\
\hline Rocky Mountain Alpine-Montane Wet Meadow & 1 & 17 & 8 & 14 \\
\hline Rocky Mountain Subalpine-Montane Fen & & 2 & 3 & 2 \\
\hline Rocky Mountain Subalpine-Montane Riparian Shrubland & & 6 & 3 & 7 \\
\hline Western North American Emergent Marsh & 4 & 9 & 6 & 10 \\
\hline \multicolumn{5}{|l|}{ Physicochemical Attribute } \\
\hline Northern Rocky Mountain Wooded Vernal Pool & & & 1 & \\
\hline Rocky Mountain Alpine-Montane Wet Meadow & 15 & 12 & 6 & 7 \\
\hline Rocky Mountain Subalpine-Montane Fen & 5 & 1 & & 1 \\
\hline Rocky Mountain Subalpine-Montane Riparian Shrubland & 5 & 6 & 2 & 3 \\
\hline Western North American Emergent Marsh & 6 & 9 & 6 & 8 \\
\hline \multicolumn{5}{|l|}{ Hydrologic Attribute } \\
\hline Northern Rocky Mountain Wooded Vernal Pool & 1 & & & \\
\hline Rocky Mountain Alpine-Montane Wet Meadow & 36 & 2 & 1 & 1 \\
\hline Rocky Mountain Subalpine-Montane Fen & 6 & & 1 & \\
\hline Rocky Mountain Subalpine-Montane Riparian Shrubland & 14 & 2 & & \\
\hline Western North American Emergent Marsh & 27 & 2 & & \\
\hline
\end{tabular}

systems, indicating that hydrologic impacts were not evident at most sites.

Scores were lowest for the Vegetation attribute across ecological systems. In particular, wet meadows and emergent marshes had the lowest scores for this attribute.

\section{Stressors}

The scope and severity of each observed stressor were recorded both within the AA and within a 200-m envelope around the AA to help identify potential impacts to wetland condition. Fewer stressors were recorded in the AA than in the 200-m envelope around the AA (Table 13). This is partially attributable to the requirement that at least $90 \%$ of the AA be placed within a wetland, so stressors like paved roads cannot be included in an AA. Most AAs had some stressors impacting the Landscape Context and the Vegetation attributes (57\% and $76 \%$ of sampled wetlands, respectively). Yet, few AAs had stressors impacting the Physicochemical and Hydrologic attributes (6\% and $11 \%$ of sampled wetlands, respectively). A similar pattern was seen for stressors in the 200-m envelope around the AA. The majority of sampled wetlands had stressors impacting the 
Table 13. Stressors observed in the assessment area (AA) and the 200-m envelope around the AA and the corresponding number of sampled wetland sites, categorized by EIA attribute.

\begin{tabular}{|c|c|c|}
\hline \multirow[b]{2}{*}{ Landscape Context } & \multicolumn{2}{|c|}{ Number of Sites } \\
\hline & AA & $200 \mathrm{~m}$ \\
\hline Domestic or commercial development & 3 & 14 \\
\hline Recreation or human visitation & 14 & 40 \\
\hline Dryland farming & -- & 1 \\
\hline Livestock grazing & 39 & 40 \\
\hline Disturbed fallow lands dominated by exotic species & 2 & -- \\
\hline Intensive logging ( $50-75 \%$ trees of $>50 \mathrm{~cm}$ diameter removed) & -- & 1 \\
\hline Selective logging ( $<50 \%$ of trees $>50 \mathrm{~cm}$ diameter removed) & 3 & 11 \\
\hline Paved surfaces (e.g., roads, parking lots) & -- & 3 \\
\hline Unpaved roads & 10 & 42 \\
\hline Railroads & -- & 1 \\
\hline Beetle-killed Pinus species & 2 & 18 \\
\hline \multicolumn{3}{|l|}{ Vegetation } \\
\hline Vegetation conversion & 4 & 4 \\
\hline Browsing of woody vegetation by native ungulates & 43 & 30 \\
\hline Livestock grazing & 39 & 40 \\
\hline Beaver activity & 2 & 1 \\
\hline \multicolumn{3}{|l|}{ Physicochemical } \\
\hline Gravel pits, open pit mining & -- & 1 \\
\hline Filling or dumping of sediment or fill & -- & 2 \\
\hline Other mining activity or abandoned mines & -- & 2 \\
\hline Trash or refuse dumping & 6 & 4 \\
\hline \multicolumn{3}{|l|}{ Hydrologic } \\
\hline Impoundment of flowing water & 3 & 3 \\
\hline Dredged inlet/outlet channel & 2 & 1 \\
\hline Engineered channel (e.g., riprap) & -- & 1 \\
\hline Pumps, diversions, or ditches that move water into wetland & 3 & 2 \\
\hline Pumps, diversions, or ditches that move water out of wetland & 1 & 1 \\
\hline Berms/Dikes/Levees & 2 & 1 \\
\hline Beaver activity & 2 & 1 \\
\hline
\end{tabular}

Landscape Context and the Vegetation attributes (84\% and 65\% of sampled wetlands, respectively), whereas few wetlands had stressors impacting the Physicochemical and Hydrologic attributes (9\% and $8 \%$ of sampled wetlands, respectively).

All but two sites had overall stressor impact ratings within the AA of No Impact or Low Impact (Table 14). By attribute, Landscape Context and Vegetation showed a range of impact ratings for wet meadows, riparian shrublands, and emergent marshes, although most sites had impact ratings of No Impact to Low Impact (Table 15). Overall stressor impact ratings were similar for the $200-\mathrm{m}$ envelope around the AA (Table 16) and by attribute (Table 17).

\section{Level 3 Assessments}

We completed 29 Level 3 intensive assessments within the project area, encountering 309 plant taxa. Of these, 272 taxa were identified to the species level. Of the 309 total plant taxa encountered, 119 species were encountered at only one site and 57 species were encountered at only two sites. The average number of species encountered per site was 30 (range 9-49). Of the 272 species identified to species, 238 (88\%) were native species and 34 were exotic species. 
Table 14. Overall assessment area (AA) stressor impact rating by wetland ecological system for the southwest Montana basinwide assessment project area.

\begin{tabular}{|c|c|c|c|c|c|}
\hline & \multicolumn{5}{|c|}{ Impact Rating } \\
\hline & $\begin{array}{c}\text { No } \\
\text { Impact }\end{array}$ & $\begin{array}{c}\text { Low } \\
\text { Impact }\end{array}$ & $\begin{array}{c}\text { Medium } \\
\text { Impact }\end{array}$ & $\begin{array}{c}\text { High } \\
\text { Impact }\end{array}$ & $\begin{array}{c}\text { Very } \\
\text { High } \\
\text { Impact }\end{array}$ \\
\hline Northern Rocky Mountain Wooded Vernal Pool & & 1 & & & \\
\hline Rocky Mountain Alpine-Montane Wet Meadow & 28 & 11 & 1 & & \\
\hline Rocky Mountain Subalpine-Montane Fen & 6 & & 1 & & \\
\hline Rocky Mountain Subalpine-Montane Riparian Shrubland & 12 & 4 & & & \\
\hline Western North American Emergent Marsh & 21 & 8 & & & \\
\hline
\end{tabular}

Table 15. EIA attribute stressor impact rating within the assessment area (AA) by wetland ecological system for the southwest Montana basin-wide assessment project area.

\begin{tabular}{|c|c|c|c|c|c|}
\hline & \multicolumn{5}{|c|}{ Impact Rating } \\
\hline & $\begin{array}{c}\text { No } \\
\text { Impact }\end{array}$ & $\begin{array}{c}\text { Low } \\
\text { Impact }\end{array}$ & $\begin{array}{c}\text { Medium } \\
\text { Impact }\end{array}$ & $\begin{array}{c}\text { High } \\
\text { Impact }\end{array}$ & $\begin{array}{c}\text { Very } \\
\text { High } \\
\text { Impact }\end{array}$ \\
\hline \multicolumn{6}{|l|}{ Landscape Context } \\
\hline Northern Rocky Mountain Wooded Vernal Pool & & 1 & & & \\
\hline Rocky Mountain Alpine-Montane Wet Meadow & 21 & 8 & 8 & 2 & 1 \\
\hline Rocky Mountain Subalpine-Montane Fen & 5 & 1 & & & 1 \\
\hline Rocky Mountain Subalpine-Montane Riparian Shrubland & 6 & 8 & 1 & & 1 \\
\hline Western North American Emergent Marsh & 8 & 14 & 4 & 2 & 1 \\
\hline \multicolumn{6}{|l|}{ Vegetation } \\
\hline Northern Rocky Mountain Wooded Vernal Pool & & & 1 & & \\
\hline Rocky Mountain Alpine-Montane Wet Meadow & 11 & 20 & 6 & 2 & 1 \\
\hline Rocky Mountain Subalpine-Montane Fen & 3 & 2 & 1 & & 1 \\
\hline Rocky Mountain Subalpine-Montane Riparian Shrubland & 3 & 10 & 2 & 1 & \\
\hline Western North American Emergent Marsh & 5 & 14 & 4 & 5 & 1 \\
\hline \multicolumn{6}{|l|}{ Physicochemical } \\
\hline Northern Rocky Mountain Wooded Vernal Pool & & 1 & & & \\
\hline Rocky Mountain Alpine-Montane Wet Meadow & 38 & 2 & & & \\
\hline Rocky Mountain Subalpine-Montane Fen & 6 & 1 & & & \\
\hline Rocky Mountain Subalpine-Montane Riparian Shrubland & 14 & 1 & 1 & & \\
\hline Western North American Emergent Marsh & 29 & & & & \\
\hline \multicolumn{6}{|l|}{ Hydrologic } \\
\hline Northern Rocky Mountain Wooded Vernal Pool & 1 & & & & \\
\hline Rocky Mountain Alpine-Montane Wet Meadow & 36 & 3 & 1 & & \\
\hline Rocky Mountain Subalpine-Montane Fen & 6 & 1 & & & \\
\hline Rocky Mountain Subalpine-Montane Riparian Shrubland & 13 & 3 & & & \\
\hline Western North American Emergent Marsh & 27 & 1 & 1 & & \\
\hline
\end{tabular}


Table 16. Overall stressor impact rating within the 200-m envelope around the assessment (AA) by wetland ecological system for the southwest Montana basin-wide assessment project area.

\begin{tabular}{lccccc}
\hline & \multicolumn{5}{c}{ Impact Rating } \\
\cline { 2 - 5 } & \multicolumn{1}{c}{$\begin{array}{c}\text { No } \\
\text { Impact }\end{array}$} & $\begin{array}{c}\text { Low } \\
\text { Impact }\end{array}$ & $\begin{array}{c}\text { Medium } \\
\text { Impact }\end{array}$ & $\begin{array}{c}\text { High } \\
\text { Impact }\end{array}$ & $\begin{array}{c}\text { High } \\
\text { Impact }\end{array}$ \\
\cline { 2 - 6 } Northern Rocky Mountain Wooded Vernal Pool & & 1 & & \\
Rocky Mountain Alpine-Montane Wet Meadow & 24 & 15 & 1 & \\
Rocky Mountain Subalpine-Montane Fen & 6 & 1 & & \\
Rocky Mountain Subalpine-Montane Riparian Shrubland & 6 & 10 & & \\
Western North American Emergent Marsh & 18 & 10 & 1 & \\
Western North American Emergent Marsh & 27 & 1 & &
\end{tabular}

Table 17. EIA attribute stressor impact rating within the 200-m envelope around the assessment area (AA) by wetland ecological system for the southwest Montana basin-wide assessment project area.

\begin{tabular}{|c|c|c|c|c|c|}
\hline & \multicolumn{5}{|c|}{ Impact Rating } \\
\hline & $\begin{array}{c}\text { No } \\
\text { Impact } \\
\end{array}$ & $\begin{array}{c}\text { Low } \\
\text { Impact }\end{array}$ & $\begin{array}{c}\text { Medium } \\
\text { Impact }\end{array}$ & $\begin{array}{c}\text { High } \\
\text { Impact }\end{array}$ & $\begin{array}{c}\text { Very } \\
\text { High } \\
\text { Impact }\end{array}$ \\
\hline \multicolumn{6}{|l|}{ Landscape Context } \\
\hline Northern Rocky Mountain Wooded Vernal Pool & & & 1 & & \\
\hline Rocky Mountain Alpine-Montane Wet Meadow & 7 & 21 & 9 & 2 & 1 \\
\hline Rocky Mountain Subalpine-Montane Fen & 4 & 2 & & 1 & \\
\hline Rocky Mountain Subalpine-Montane Riparian Shrubland & 2 & 4 & 5 & 5 & \\
\hline Western North American Emergent Marsh & 2 & 17 & 5 & 4 & 1 \\
\hline \multicolumn{6}{|l|}{ Vegetation } \\
\hline Northern Rocky Mountain Wooded Vernal Pool & & 1 & & & \\
\hline Rocky Mountain Alpine-Montane Wet Meadow & 14 & 21 & 5 & & \\
\hline Rocky Mountain Subalpine-Montane Fen & 5 & 1 & 1 & & \\
\hline Rocky Mountain Subalpine-Montane Riparian Shrubland & 7 & 3 & 4 & 2 & \\
\hline Western North American Emergent Marsh & 7 & 17 & 4 & 1 & \\
\hline \multicolumn{6}{|l|}{ Physicochemical } \\
\hline Northern Rocky Mountain Wooded Vernal Pool & & 1 & & & \\
\hline Rocky Mountain Alpine-Montane Wet Meadow & 35 & 5 & & & \\
\hline Rocky Mountain Subalpine-Montane Fen & 7 & & & & \\
\hline Rocky Mountain Subalpine-Montane Riparian Shrubland & 15 & 1 & & & \\
\hline Western North American Emergent Marsh & 28 & 1 & & & \\
\hline \multicolumn{6}{|l|}{ Hydrologic } \\
\hline Northern Rocky Mountain Wooded Vernal Pool & 1 & & & & \\
\hline Rocky Mountain Alpine-Montane Wet Meadow & 37 & 1 & 1 & 1 & \\
\hline Rocky Mountain Subalpine-Montane Fen & 7 & & & & \\
\hline Rocky Mountain Subalpine-Montane Riparian Shrubland & 14 & 1 & 1 & & \\
\hline Western North American Emergent Marsh & 27 & 1 & & & \\
\hline
\end{tabular}


The most commonly encountered plant species was common yarrow (Achillea millefolium; Table 18). Four of the 10 most commonly encountered plant species were exotic species, including one state-listed noxious weed species, Canada thistle (Cirsium arvense).

\section{Floristic Quality Assessment}

We calculated floristic quality assessment (FQA) metrics for all 29 Level 3 assessment sites. Average mean C-value at these sites was 4.37. Most Cvalues for native species encountered fell between 5 and 7 (Figure 22).
Fens had the highest mean C-value (4.94), and riparian shrublands had the lowest mean C-value (3.90; Table 19). In general, values for metrics related to species richness were highest for riparian shrublands and lowest for emergent marshes, whereas fens had the highest values for metrics related to $\mathrm{C}$-values and floristic quality indices (FQI).

\section{Comparisons of Level 1, 2, \& 3 Results}

To understand the effectiveness of this assessment framework in determining the condition of

Table 18. Ten most commonly encountered plant species during Level 3 intensive assessments in the southwest Montana basin-wide assessment project area.

\begin{tabular}{lcccc}
\hline \multicolumn{1}{c}{ Scientific Name } & $\begin{array}{c}\text { Number of Sites } \\
\text { Encountered }\end{array}$ & C-Value & $\begin{array}{c}\text { Wetland Indicator } \\
\text { Status** }\end{array}$ & $\begin{array}{c}\text { Native } \\
\text { Status }\end{array}$ \\
\hline Achillea millefolium & 19 & 4 & FACU & Native \\
Taraxacum officinale & 19 & 0 & FACU & Exotic \\
Carex aquatilis & 17 & 6 & OBL & Native \\
Carex utriculata & 16 & 4 & OBL & Native \\
Geum macrophyllum & 16 & 6 & FACW- & Native \\
Poa pratensis & 16 & 0 & FAC & Exotic \\
Trifolium repens & 15 & 0 & FAC- & Exotic \\
Cirsium arvense* & 14 & 0 & FAC- & Exotic \\
Potentilla gracilis & 14 & 4 & FAC & Native \\
\hline
\end{tabular}

*Cirsium arvense is a state-listed noxious weed species in Montana

**1988 U.S. Fish and Wildlife Service

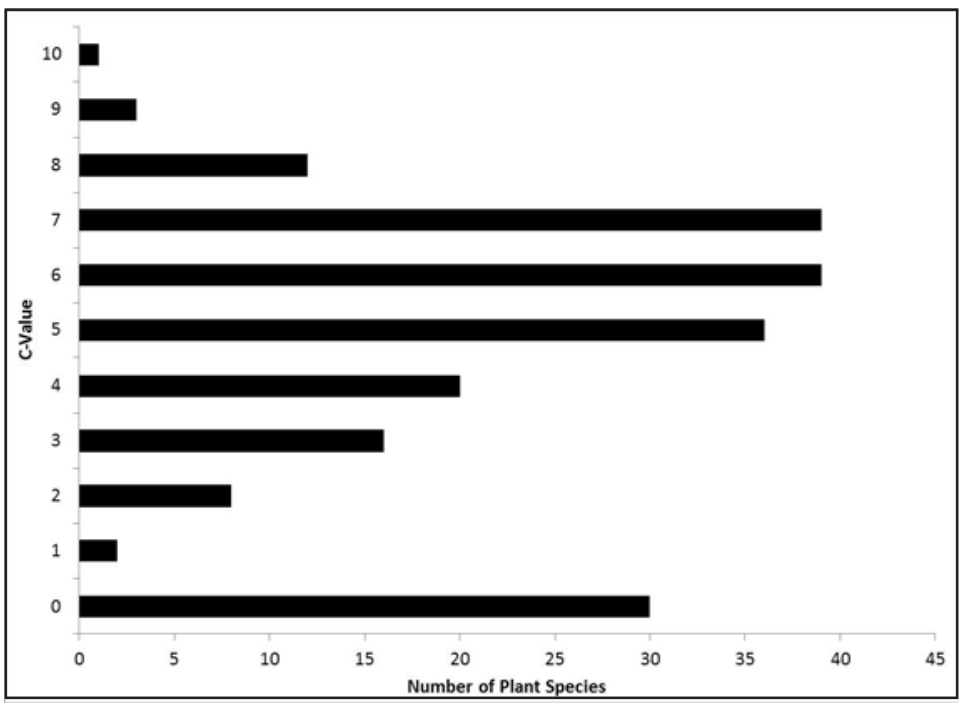

Figure 22. Frequency distribution of $C$-values of plant species encountered during Level 3 assessments in the southwest Montana basin-wide assessment project. 
Table 19. Means and standard deviations of all FQA metrics considered by Ecological System for Level 3 assessments completed in the southwest Montana basin-wide assessment project area.

\begin{tabular}{|c|c|c|c|c|c|c|c|c|}
\hline & \multicolumn{2}{|c|}{$\begin{array}{l}\text { Wet Meadow } \\
\qquad(\mathbf{n}=\mathbf{1 0})\end{array}$} & \multicolumn{2}{|c|}{$\begin{array}{l}\text { Fen } \\
(n=4)\end{array}$} & \multicolumn{2}{|c|}{$\begin{array}{c}\text { Riparian } \\
\text { Shrubland }(\mathrm{n}=\mathbf{8})\end{array}$} & \multicolumn{2}{|c|}{$\begin{array}{c}\text { Emergent } \\
\text { Marsh }(n=7)\end{array}$} \\
\hline & Mean & SD & Mean & SD & Mean & SD & Mean & SD \\
\hline Number of native species & 24.20 & 6.41 & 26.00 & 13.64 & 27.25 & 9.57 & 22.43 & 13.77 \\
\hline Total species & 28.20 & 6.16 & 28.00 & 13.98 & 33.13 & 10.19 & 27.29 & 15.04 \\
\hline Number of exotic species & 3.70 & 2.98 & 1.75 & 1.50 & 4.75 & 3.49 & 4.29 & 3.09 \\
\hline Graminoid cover & 10.44 & 9.67 & 6.78 & 2.40 & 4.58 & 3.53 & 6.55 & 2.79 \\
\hline Percent exotic species & 16.85 & 13.16 & 6.06 & 5.88 & 19.04 & 13.00 & 22.28 & 22.16 \\
\hline Mean C-value of all species & 4.54 & 1.10 & 4.94 & 0.71 & 3.90 & 0.69 & 4.39 & 1.17 \\
\hline $\begin{array}{l}\text { Cover-weighted Mean C-value of } \\
\text { all species }\end{array}$ & 2.99 & 1.61 & 3.10 & 2.06 & 2.66 & 1.18 & 2.73 & 1.93 \\
\hline Mean C-value of native species & 5.32 & 0.61 & 5.29 & 0.87 & 4.81 & 0.43 & 5.22 & 0.49 \\
\hline $\begin{array}{l}\text { Cover-weighted Mean C-value of } \\
\text { native species }\end{array}$ & 4.54 & 0.95 & 4.73 & 1.13 & 4.30 & 0.87 & 4.44 & 1.20 \\
\hline FQI of all species & 24.03 & 6.67 & 26.10 & 10.29 & 22.42 & 6.33 & 22.04 & 8.45 \\
\hline Cover-weighted FQI of all species & 19.25 & 8.15 & 24.52 & 16.64 & 18.74 & 7.08 & 18.90 & 13.14 \\
\hline FQI of native species & 26.09 & 5.68 & 26.96 & 11.06 & 24.98 & 6.38 & 23.92 & 8.51 \\
\hline Adjusted FQI of native species & 49.26 & 8.35 & 50.70 & 8.96 & 43.42 & 5.84 & 47.23 & 8.23 \\
\hline $\begin{array}{l}\text { Cover-weighted FQI of native } \\
\text { species }\end{array}$ & 22.45 & 6.81 & 24.18 & 11.44 & 21.87 & 5.75 & 21.07 & 11.34 \\
\hline Adjusted cover-weighted FQI & 48.96 & 8.01 & 49.23 & 10.89 & 47.97 & 10.03 & 48.93 & 10.42 \\
\hline $\begin{array}{l}\text { Average Wetland Indicator Status } \\
\text { value }\end{array}$ & 3.33 & 0.30 & 3.68 & 0.43 & 3.24 & 0.30 & 3.54 & 0.47 \\
\hline
\end{tabular}

wetlands in the southwest Montana project area, we compared the results of each assessment level with the preceding level of assessment (e.g. Level 3 results compared with Level 2 results and Level 2 results compared with Level 1 results).

Landscape level (Level 1) ratings from the LIM showed a moderate negative correlation with overall Level 2 wetland condition scores $(\mathrm{r}=$ -0.60 ). LIM values of around 10,000 indicate minimally disturbed areas, whereas values of 25,000 or higher indicate highly disturbed areas. Level 2 assessment scores showed a general trend of increasing with decreasing LIM values (Figure 23).

Impact ratings within the 200-m envelope around the AA and within the AA showed moderate negative correlations with overall Level 2 assessment scores $(\mathrm{r}=-0.71$ and $\mathrm{r}=-0.61$, respectively; Table 20 and 21). All Level 2 attributes scores showed moderate negative correlations with at least one impact rating category at either scale except the Vegetation attribute, indicating our current stressor list may not adequately capture potential impacts to vegetation condition.

Of the 16 vegetation metrics evaluated in the FQA, only five metrics were correlated with stressors, overall wetland condition score, or both, and were not redundant with other vegetation metrics (Table 22). These metrics were cover-weighted mean $\mathrm{C}$-value of all species, FQI for all species, coverweighted FQI of all species, cover-weighted FQI of native species, and adjusted FQI. Formulas used to calculate vegetation metrics are included in Appendix F.

When evaluating estimates of stressor extent, only three stressors showed a moderate negative correlation $(r \geq-0.5)$ with vegetation metrics 


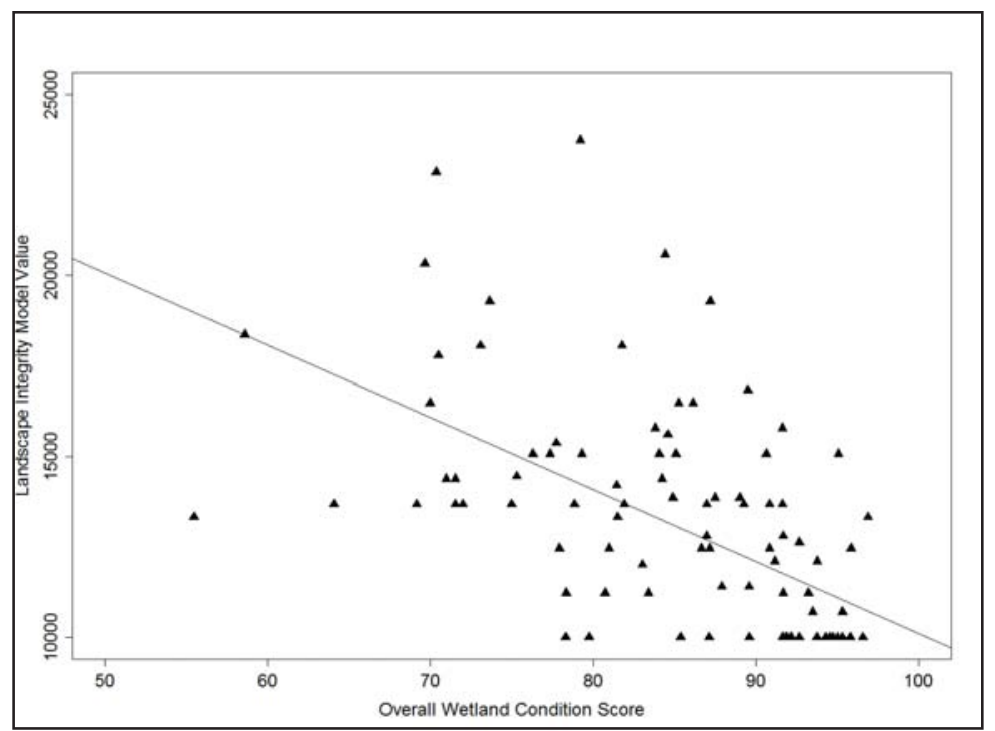

Figure 23. Correlation of landscape integrity model (LIM) values with overall Level 2 wetland condition scores.

Table 20. Spearman's correlation coefficients of Impact Category scores calculated within a 200-m envelope of the assessment area with Level 2 assessment attribute and overall scores.

\begin{tabular}{lccccc}
\hline & \multicolumn{5}{c}{ Level 2 Assessment Scores } \\
\cline { 2 - 6 } Impact Category & $\begin{array}{c}\text { Landscape } \\
\text { Context }\end{array}$ & Vegetation & Physicochemical & Hydrologic & $\begin{array}{c}\text { Overall } \\
\text { Condition }\end{array}$ \\
\hline Landscape Context & -0.72 & -0.37 & -0.58 & -0.20 & -0.70 \\
Vegetation & -0.33 & -0.24 & -0.51 & -0.09 & -0.43 \\
Physicochemical & -0.35 & -0.16 & -0.18 & -0.06 & -0.28 \\
Hydrologic & -0.14 & 0.07 & -0.00 & -0.52 & -0.12 \\
Overall Impact Rating & -0.74 & -0.37 & -0.56 & -0.34 & -0.71 \\
\hline
\end{tabular}

Table 21. Spearman's correlation coefficients of Impact Category scores calculated within the assessment area with Level 2 assessment attribute and overall scores.

\begin{tabular}{lccccc}
\hline & \multicolumn{5}{c}{ Level 2 Assessment Scores } \\
\cline { 2 - 6 } Impact Category & $\begin{array}{c}\text { Landscape } \\
\text { Context }\end{array}$ & Vegetation & Physicochemical & Hydrologic & $\begin{array}{c}\text { Overall } \\
\text { Condition }\end{array}$ \\
\hline Landscape Context & -0.44 & -0.17 & -0.67 & -0.22 & -0.54 \\
Vegetation & -0.30 & -0.26 & -0.51 & -0.11 & -0.42 \\
Physicochemical & -0.32 & -0.24 & -0.22 & -0.14 & -0.31 \\
Hydrologic & -0.25 & -0.08 & -0.24 & -0.54 & -0.26 \\
Overall Impact Rating & -0.53 & -0.19 & -0.71 & -0.36 & -0.61 \\
\hline
\end{tabular}

(Table 23). These were percent of the 200-m envelope comprised of domestic or commercial development, percent of the 200-m envelope grazed by livestock, and the length in meters of unpaved roads within the 200-m envelope. 
Table 22. Vegetation metrics included in the floristic quality assessment (FQA), and their response to stressors within the assessment area (AA), within the 200-m envelope surrounding the AA, and their relationship with overall wetland condition scores. Response categories are defined as follows: poor discriminatory power refers to metrics with a weak correlation $(r<0.5)$ with overall wetland condition; poor correlation refers to metrics with weak correlation $(r<0.5)$ with stressors at either scale and overall condition scores; redundant refers to vegetation metrics that are highly correlated $(r>0.9)$ with other vegetation metrics; and correlated indicates metrics that show a response to either stressors or overall wetland condition scores.

\begin{tabular}{lcccc}
\hline Metric & Response & $\begin{array}{c}\text { Response } \\
\text { to stressors } \\
\text { (AA) }\end{array}$ & $\begin{array}{c}\text { Response } \\
\text { to stressors } \\
\mathbf{( 2 0 0 ~} \mathbf{~ m})\end{array}$ & $\begin{array}{c}\text { Overall } \\
\text { Condition } \\
\text { Score }\end{array}$ \\
\hline Total species richness & poor discriminatory power & -0.29 & -0.30 & 0.09 \\
Native species richness & poor discriminatory power & -0.44 & -0.41 & 0.27 \\
Non-native species richness & poor correlation & 0.39 & 0.26 & -0.45 \\
\% Non-native species & poor correlation & 0.49 & 0.39 & -0.49 \\
Cover of native graminoids & poor correlation & -0.15 & -0.13 & 0.05 \\
Mean C-value of all species & redundant & -0.68 & -0.65 & 0.66 \\
Mean C-value of native species & redundant & -0.73 & -0.78 & 0.71 \\
$\begin{array}{l}\text { Cover-weighted Mean C-value } \\
\text { of all species }\end{array}$ & correlated & -0.69 & -0.47 & 0.54 \\
$\begin{array}{l}\text { Cover-weighted Mean C-value } \\
\text { of native species }\end{array}$ & redundant & -0.46 & -0.43 & 0.59 \\
$\begin{array}{l}\text { FQI of all species } \\
\text { FQI of native species }\end{array}$ & correlated & -0.67 & -0.63 & 0.53 \\
$\begin{array}{l}\text { Cover-weighted FQI of all } \\
\text { species }\end{array}$ & redundant & -0.62 & -0.63 & 0.48 \\
$\begin{array}{l}\text { Cover-weighted FQI of native } \\
\text { species }\end{array}$ & correlated & -0.60 & -0.37 & 0.43 \\
$\begin{array}{l}\text { Adjusted FQI } \\
\text { Adjusted cover-weighted FQI }\end{array}$ & correlated & -0.57 & -0.57 & 0.52 \\
$\begin{array}{l}\text { Average Wetland Indicator } \\
\text { Status }\end{array}$ & correlated & -0.75 & -0.75 & 0.68 \\
\hline
\end{tabular}




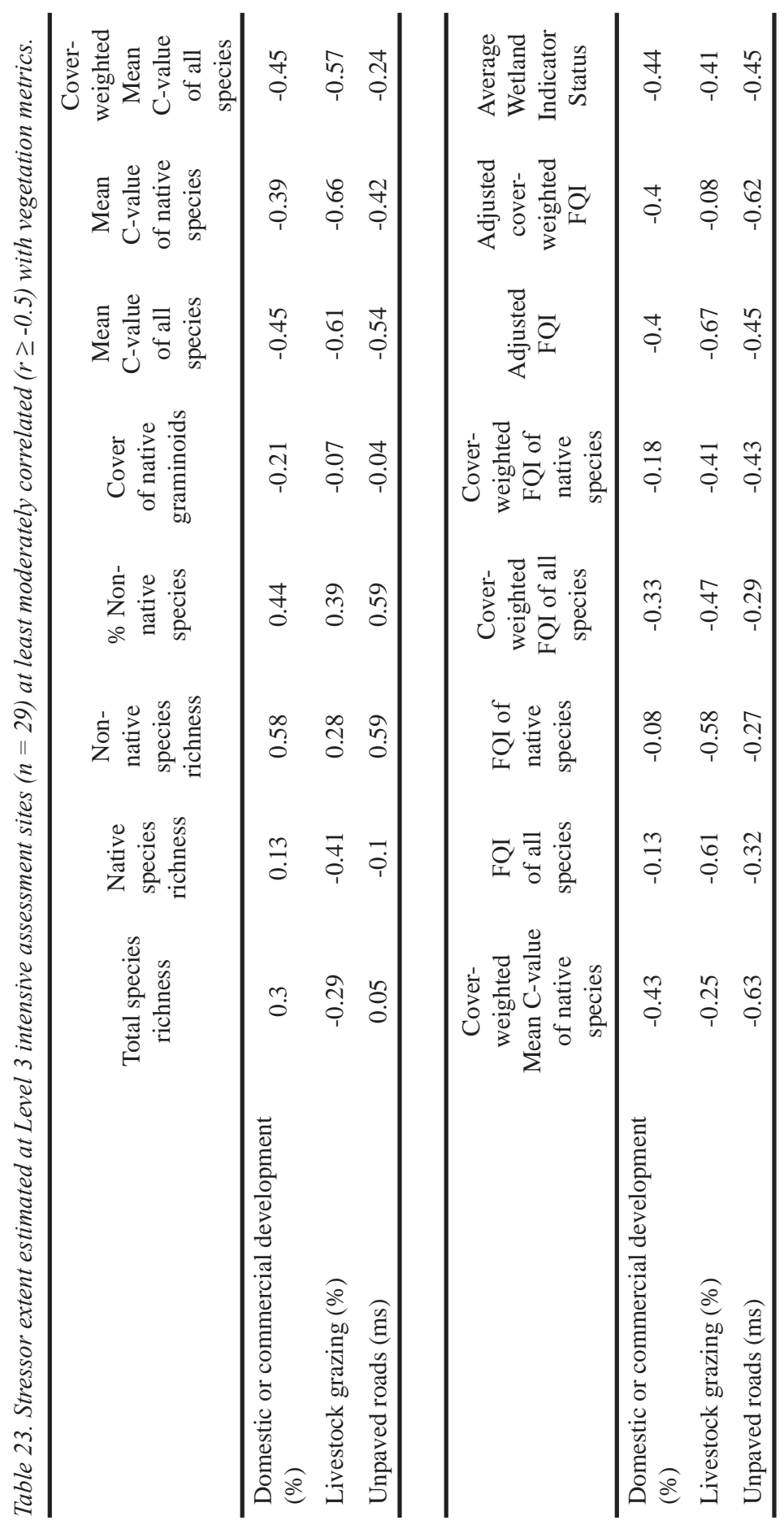




\section{Discussion}

Results from our wetland landscape profile revealed that wetlands make up about $3 \%$ of the total southwest Montana project area. Palustrine emergent wetlands with temporary or seasonal flooding regimes comprised $80 \%$ of all mapped wetlands. These wetlands serve important water storage and groundwater recharge functions. Only $0.4 \%$ of mapped wetlands were classified as saturated wetlands; however, this hydrologic regime is very difficult to interpret through aerial photointerpretation. The occurrence of these wetland types, which includes fens and other slope wetlands, is likely underestimated in digital mapping. The MTNHP relies on multiple ancillary data layer to classify these wetlands correctly. We are currently improving our methods of identifying these important wetland types in our digital wetland mapping projects.

Wetland alterations were primarily limited to lacustrine and riverine wetlands. These alterations were in the form of impoundments or excavations. However, assigning these modifiers to digitally mapped wetlands does not capture the impact of upstream water withdrawals and other water management uses. Only 3\% of palustrine wetlands were classified as anthropogenically altered through digital mapping, although we could not estimate the wetland acres lost as a result of these alterations.

Our Level 1 landscape characterization of the project area showed the primary land use in the project area is agricultural practices related to irrigated hay pastures and cropland. Palustrine wetlands had very few hydrologic modifications in the form of canals and ditches, wells, and water rights. On average, palustrine wetlands were less than three ac in size. These wetlands had relatively large perimeter to area ratios indicating most wetlands had a large amount of edge habitat, although these edges are surrounded by a relatively intact terrestrial landscape. The average distance to the nearest five mapped wetlands was $236 \mathrm{~m}$. Inter-wetland distance has important demographic implications for wetland-dependent species, particularly amphibians (Gibbs 1993).
Dispersal across terrestrial habitats can be difficult for wetland-adapted species, although dispersal distances vary by species, and non-vagile species such as plants are dependent to some degree on wetland animals for dispersal. Given the relatively low mean inter-wetland distances observed, wetlands species in the project area may be able to disperse to other wetlands with a high degree of success.

Wetlands in the southwest Montana project area are diverse and represent wet meadows, emergent marshes, riparian shrublands, and fens. Both slope and basin fens occur in the project area. Slope fens rely on groundwater to maintain soil saturation for formation of the organic layer. Basin fens occur as floating peat mats adjacent to ponds and small lakes.

Overall, 72\% of wetlands sampled with Level 2 assessments were near reference or had only slight departure from reference standard. Another 24\% of sampled wetlands were rated as a moderate departure from reference standard, indicating some form of management action or restoration may be warranted.

By Level 2 attribute, both Landscape Context and Vegetation had sites rated as a severe departure from reference standard. For the Landscape Context attribute, $62 \%$ of sites were still rated as near reference or as a slight departure from reference standard. The Vegetation attribute, however, had $37 \%$ of sites rated as a severe departure from reference standard, and only $5 \%$ of sites were rated near reference standard. This was due largely to the presence of nonnative plant species, although we did not differentiate these species based on their ecological amplitude, impact, or degree of invasiveness. Physicochemical and hydrologic attribute scores were high, reiterating results found in our Level 1 characterization, and resulting in high overall wetland condition scores.

Livestock grazing, recreation or human visitation, unpaved roads, and browsing by native ungulates 
were the most commonly observed stressors both within wetlands and in lands surrounding the wetland sites. Overall, most sites had No Impact or Low Impact ratings, even when examined by attribute. This result emphasizes a disparity between our vegetation metrics and our current list of stressors. We will continue to examine and modify our stressor list, so that these stressors can further elucidate observed wetland condition.

Most native species encountered at sampled wetlands had $\mathrm{C}$-values $\geq 5$, indicating most species were those found in wetlands with minimal disturbance. However, four of the 10 most commonly encountered plant species were exotic, including the state-listed noxious weed species Cirsium arvense. This species reproduces primarily by rhizomatous growth and also by windborne seeds, and once present, is difficult or impossible to eradicate.

Floristic quality assessment metrics most correlated with wetland condition and most responsive to disturbance were related to C-values and FQIs. These results are unsurprising as these values are based on the plants species' tolerance of disturbance, so they would be expected to be good indicators of wetland condition (Lopez and Fennessy 2002).

Results from this project indicate the wetlands sampled in these southwest Montana watersheds are in relatively good condition. Wetlands had intact buffers, few hydrologic impacts, and low to moderate impacts to physicochemical properties. Scores were lowest for the Vegetation attribute across ecological systems. The component metrics within this attribute integrate the effects of multiple disturbances over multiple spatial scales. The other attributes focus either on the area around the AA (Landscape Context attributes) or immediate on-site impacts (Physicochemical and Hydrologic attributes), so these attributes reflect only certain aspects of overall wetland condition. Additionally, most vegetation metrics were not well correlated with stressor impacts, indicating our current list of stressors is not adequately reflecting impacts to vegetation condition. We will continue to explore additional approaches to account for anthropogenic impacts on plant species composition.

This project demonstrated how various levels of wetland assessment can be collected and summarized to provide robust assessments of wetland condition at a watershed scale. Level 1 wetland assessments were used to create wetland landscape profiles and to provide landscape characterizations of landscape-level stressors throughout the project area. These Level 1 assessments provided insights into the potential impacts on wetland condition and are an essential foundation for wetland assessment efforts. Additionally, Level 1 assessments can be completed at a relatively low cost and level of effort. Level 2 field-based assessments provided site-specific information on wetland condition and the site-level stressors impacting these wetlands, further informing management and conservation of wetland resources. The use of a standardized protocol such as MTNHP's Ecological Integrity Assessment allows for comparison of condition scores across wetland systems, providing the potential to assess status and trends of wetland condition over time. Level 2 assessments also provide context for interpretation of Level 3 intensive assessments. Level 3 intensive assessments are necessary to calibrate and validate indicators of wetland condition measured from Level 1 and Level 2 assessments. The high level of effort involved in Level 3 assessments makes them less feasible for determining wetland condition at larger scales. However, Level 3 assessments can be very powerful tools for determining whether particular conservation or management goals have been attained. 


\section{Literature Cited}

Andreas, B. K., J. J. Mack, and J. S. McCormac. 2004. Floristic quality assessment index (FQAI) for vascular plans and mosses for the State of Ohio. Ohio Environmental Protection Agency, Division of Surface Water, Wetland Ecology Group, Columbus, Ohio.

Brinson, M. M. 1993. A hydrogeomorphic classification for wetlands. Technical Report WRPDE-4, Waterways Experiment Station, Army Corps of Engineers, Vicksburg, Mississippi.

Brooks, R. P., D. H. Wardrop, and C. A. Cole. 2006. Inventorying and monitoring wetland condition and restoration potential on a watershed basis with examples from Spring Creek watershed, Pennsylvania, USA. Environmental Management 38:673-687.

Comer, P., D. Faber-Langendoen, R. Evans, S. Gawler, C. Josse, G. Kittel, S. Menard, M. Pyne, M. Reid, K. Schulz, K. Snow, and J. Teague. 2003. Ecological Systems of the United States: A Working Classification of U.S. Terrestrial Systems. NatureServe, Arlington, VA.

Cowardin, L. M., V. Carter, F. C. Golet, and E. T. LaRoe. 1979. Classification of wetlands and deepwater habitats of the United States. U.S. Fish and Wildlife Service, Washington, D.C. FWS/OBS-79/31.

Cronk, J. K., M. S. Fennessy. 2001. Wetlands plants: biology and ecology. CRC Press, Boca Raton, FL.

Dorn, R. D. 1984. Vascular plants of Montana. Mountain West Publishing, Cheyenne, WY.

Faber-Langendoen, D., C. Hedge, M. Kost, S. Thomas, L. Smart, R. Smyth, J. Drake, and S. Menard, 2011. Assessment of wetland ecosystem condition across landscape regions: a multimetric approach. NatureServe, Arlington, VA. + Appendices.
Gibbs, J. P. 1993. Importance of small wetlands for the persistence of local populations of wetlandassociated animals. Wetlands 13:25-31.

Grossman, D. H., D. Faber-Langendoen, A. S. Weakley, M. Anderson, P. Bourgeron, R. Crawford, K. Goodin, S. Landaal, K. Metzler, K. D. Patterson, M. Pyne, M. Reid, and L. Sneddon. 1998. International classification of ecological communities: terrestrial vegetation of the United States. Volume I. The National Vegetation Classification System: development, status, and applications. The Nature Conservancy, Arlington, Virginia, USA.

Hauer, F. R., B. J. Cook, M. C. Gilbert, E. J. Clairain, Jr., and R. D. Smith. 2002. A regional guidebook for applying the hydrogeomorphic approach to assessing wetland functions of intermontane prairie pothole wetlands in the northern Rocky Mountains. ERDC/EL TR-02-7.

Helzer, C. J. and D. E. Jelinski. 1999. The relative importance of patch area and the perimeter-area ratio to grassland breeding birds. Ecological Applications 9:1448-1458.

Johnson, B. 2005. Hydrogeomorphic wetland profiling: an approach to landscape and cumulative impacts analysis. EPA/620/R05/001. U.S. Environmental Protection Agency, Washington, D.C.

Karr, J. R., and D. R. Dudley. 1981. Ecological perspectives on water quality goals. Environmental Management 5:55-68.

Karr, J. R. and E. W. Chu. 1999. Restoring life in running waters: better biological monitoring. Island Press, Covelo, CA.

Kincaid, T., and T. Olsen. 2009. spsurvey: Spatial survey design and analysis. R package version 2.1. 
Lemly, J. L., and J. Rocchio. 2009. Vegetation index of biotic integrity (VIBI) for headwater wetlands in the southern Rocky Mountains. Version 2.0: Calibration of selected VIBI models. Colorado Natural Heritage Program.

Lopez R. D., and M. S. Fennessy. 2002. Testing the floristic quality assessment index as an indicator of wetland condition. Ecological Applications 12:487-497.

Mack, J. J. 2004. Integrated Wetland Assessment Program. Part 4: Vegetation Index of Biotic Integrity (VIBI) and Tiered Aquatic Life Uses (TALUs) for Ohio wetlands. Ohio EPA Technical Report WET/2004-4. Ohio Environmental Protection Agency, Wetland Ecology Group, Division of Surface Water, Columbus, Ohio.

McIntyre, C., K. R. Newlon, L. K. Vance, and M. D. Burns. 2011. Milk, Marias, and St. Mary monitoring: developing a long-term rotating basin wetland assessment and monitoring strategy for Montana. Helena (Mont.): Montana Natural Heritage Program.

McNab, W. H., and P. E. Avers, eds. 1994. Ecological subregions of the United States: section descriptions. U.S. Department of Agriculture, Forest Service. Publication WO-WSA-5, Washington, D.C.

Miller, S. J., and D. H. Wardrop. 2006. Adapting a floristic quality assessment index to indicate anthropogenic disturbance in central Pennsylvania wetlands. Ecological Indicators. 6:313-326.

Montana Department of Revenue. 2010. Revenue Final Land Unit Classification.

Montana Natural Heritage Program (MTNHP). 2010a. Montana Land Cover/Land Use Theme. Based on classifications originally developed by the University of Idaho, Sanborn and the MTNHP for the Pacific Northwest ReGAP project. Helena, Montana.
Montana Natural Heritage Program (MTNHP). 2010b. Montana Ecological Integrity Assessment Field Manual.

Munsell Color Company. 2000. Munsell Soil Color Charts. Revised washable edition. New Windsor, Gretag Macbeth.

National Research Council. 2001. Compensating for wetland losses under the Clean Water Act. National Academy Press, Washington DC, USA.

Nesser, J. A., G. L. Ford, C. L. Maynard, and D. S. Page-Dumroese. 1997. Ecological units of the northern region: subsections. General Technical Report. INT-GTR-369. Ogden, UT: U.S. Department of Agriculture, Forest Service, Intermountain Research Station. 88 pp.

Omernik, J. M. 1987. Ecoregions of the conterminous United States. Map (scale 1:7,500,00). Annals of the Association of American Geographers 77:118-125.

Peet, R. K., T. R. Wentworth, and P. S. White. 1998. A flexible, multipurpose method for recording vegetation composition and structure. Castanea 63: 262-274.

R Development Core Team. 2009. R: A language and environment for statistical computing. $\mathrm{R}$ Foundation for Statistical Computing, Vienna, Austria. ISBN 3-900051-07-0, URL http:// www.R-project.org.

Rocchio, J. 2006. Vegetation index of biotic integrity for Southern Rocky Mountain fens, wet meadows, and riparian shrublands: phase 1 final report. Unpublished report prepared for the Colorado Department of Natural Resources and US EPA Region 8. Colorado Natural Heritage Program, Colorado State University, Fort Collins, Colorado. 
Rocchio, J. 2007. Assessing ecological condition of headwater wetlands in the Southern Rocky Mountains using a vegetation index of biotic integrity. (Version 1.0). Unpublished report prepared for the Colorado Department of Natural Resources and US EPA Region 8. Colorado Natural Heritage Program, Colorado State University, Fort Collins, Colorado.

Stevens, D. L., Jr., and A. R. Olsen. 2004. Spatially balanced sampling of natural resources. Journal of American Statistical Association 99:262-278.

Stevens, Jr., D. L., and S. F. Jensen. 2007. Sample design, execution, and analysis for wetland assessment. Wetlands 27:515-523.

Stoddard, J. L., D. P. Larsen, C. P. Hawkins, R. K. Johnson, and R. H. Norris. Setting expectations for the ecological condition of streams: the concept of reference condition. Ecological Applications 16:1267-1276.

Sutula, M. A., E. D. Stein, J. N. Collins, A. E. Fetscher, and R. Clark. 2006. A practical guide for the development of a wetland assessment method: the California Experience. Journal of the American Water Resources Association. 42:157-175.
Vance, L. K. 2009. Assessing wetland condition with GIS: a landscape integrity model for Montana. A report to the Montana Department of Environmental Quality and the Environmental Protection Agency. Montana Natural Heritage Program, Helena, MT. 23 pp. plus appendices.

Western Regional Climate Center. 2012. Western U.S. climate historical summaries. (http://www. wrcc.dri.edu/Climsum.html). Desert Research Institute, Reno, Nevada. Accessed March 2012.

White, D. and M. S. Fennessy. 2005. Suitability of wetland restoration potential at the watershed scale. Ecological Engineering 24:359-377.

Woods, A. J., J. M. Omernik, J. A. Nesser, J. Shelden, and S. H. Azevedo. 1999. Ecoregions of Montana (color poster with map, descriptive text, summary tables, and photographs): Reston, Virginia, U.S. Geological Survey (map scale $1: 1,500,000)$. 



\section{Appendix A. National Wetland InVentory (NWI) attribute CODES INCLUDED IN THE SOUTHWESTERN MONTANA BASIN-WIDE WETLAND ASSESSMENT SAMPLE FRAME}





\begin{tabular}{|c|c|c|c|c|}
\hline Attribute & System & Class & Regime & Modifier \\
\hline PABF & Palustrine & Aquatic Bed & Semipermanently Flooded & \\
\hline PABFb & Palustrine & Aquatic Bed & Semipermanently Flooded & Beaver \\
\hline PABFh & Palustrine & Aquatic Bed & Semipermanently Flooded & Diked/Impounded \\
\hline PABFx & Palustrine & Aquatic Bed & Semipermanently Flooded & Excavated \\
\hline PABG & Palustrine & Aquatic Bed & Intermittently Exposed & \\
\hline PABGb & Palustrine & Aquatic Bed & Intermittently Exposed & Beaver \\
\hline PABGh & Palustrine & Aquatic Bed & Intermittently Exposed & Diked/Impounded \\
\hline PEMA & Palustrine & Emergent & Temporarily Flooded & \\
\hline PEMAd & Palustrine & Emergent & Temporarily Flooded & Partially Drained/Ditched \\
\hline PEMAh & Palustrine & Emergent & Temporarily Flooded & Diked/Impounded \\
\hline PEMAx & Palustrine & Emergent & Temporarily Flooded & Excavated \\
\hline PEMB & Palustrine & Emergent & Saturated & \\
\hline PEMBb & Palustrine & Emergent & Saturated & Beaver \\
\hline PEMC & Palustrine & Emergent & Seasonally Flooded & \\
\hline PEMCh & Palustrine & Emergent & Seasonally Flooded & Diked/Impounded \\
\hline PEMCX & Palustrine & Emergent & Seasonally Flooded & Excavated \\
\hline PEMF & Palustrine & Emergent & Semipermanently Flooded & \\
\hline PEMFh & Palustrine & Emergent & Semipermanently Flooded & Diked/Impounded \\
\hline PEMFx & Palustrine & Emergent & Semipermanently Flooded & Excavated \\
\hline PFOA & Palustrine & Forested & Temporarily Flooded & \\
\hline PFOAh & Palustrine & Forested & Temporarily Flooded & Diked/Impounded \\
\hline PFOAx & Palustrine & Forested & Temporarily Flooded & Excavated \\
\hline PFOB & Palustrine & Forested & Saturated & \\
\hline PFOBb & Palustrine & Forested & Saturated & Beaver \\
\hline PSSA & Palustrine & Scrub-Shrub & Temporarily Flooded & \\
\hline PSSAh & Palustrine & Scrub-Shrub & Temporarily Flooded & Diked/Impounded \\
\hline PSSAx & Palustrine & Scrub-Shrub & Temporarily Flooded & Excavated \\
\hline PSSB & Palustrine & Scrub-Shrub & Saturated & \\
\hline PSSBb & Palustrine & Scrub-Shrub & Saturated & Beaver \\
\hline PSSBd & Palustrine & Scrub-Shrub & Saturated & Partially Drained/Ditched \\
\hline PSSC & Palustrine & Scrub-Shrub & Seasonally Flooded & \\
\hline PSSCh & Palustrine & Scrub-Shrub & Seasonally Flooded & Diked/Impounded \\
\hline
\end{tabular}



Appendix B. Palustrine National Wetland Inventory (NWI) ATTRIBUTE CODES EXCLUDED FROM THE SOUTHWESTERN

MONTANA BASIN-WIDE WETLAND ASSESSMENT SAMPLE FRAME 



\begin{tabular}{|l|l|l|l|l|}
\hline Attribute & System & \multicolumn{1}{c|}{ Class } & \multicolumn{1}{c|}{ Regime } & \multicolumn{1}{c|}{ Modifier } \\
\hline PUBF & Palustrine & Unconsolidated Bottom & Semipermanently Flooded & \\
\hline PUBFx & Palustrine & Unconsolidated Bottom & Semipermanently Flooded & Excavated \\
\hline PUBG & Palustrine & Unconsolidated Bottom & Intermittently Exposed & \\
\hline PUSA & Palustrine & Unconsolidated Shore & Temporarily Flooded & \\
\hline PUSAh & Palustrine & Unconsolidated Shore & Temporarily Flooded & Diked/Impounded \\
\hline PUSAx & Palustrine & Unconsolidated Shore & Temporarily Flooded & Excavated \\
\hline PUSC & Palustrine & Unconsolidated Shore & Seasonally Flooded & \\
\hline PUSCd & Palustrine & Unconsolidated Shore & Seasonally Flooded & Partially Drained/Ditched \\
\hline PUSCh & Palustrine & Unconsolidated Shore & Seasonally Flooded & Diked/Impounded \\
\hline PUSCx & Palustrine & Unconsolidated Shore & Seasonally Flooded & Excavated \\
\hline PABKx & Palustrine & Aquatic Bed & Artificially Flooded & Excavated \\
\hline
\end{tabular}





\section{Appendix C. Lacustrine and riverine National Wetland INVENTORY (NWI) ATTRIBUTE CODES EXCLUDED FROM THE SOUTH- WESTERN MONTANA BASIN-WIDE WETLAND ASSESSMENT SAMPLE FRAME}





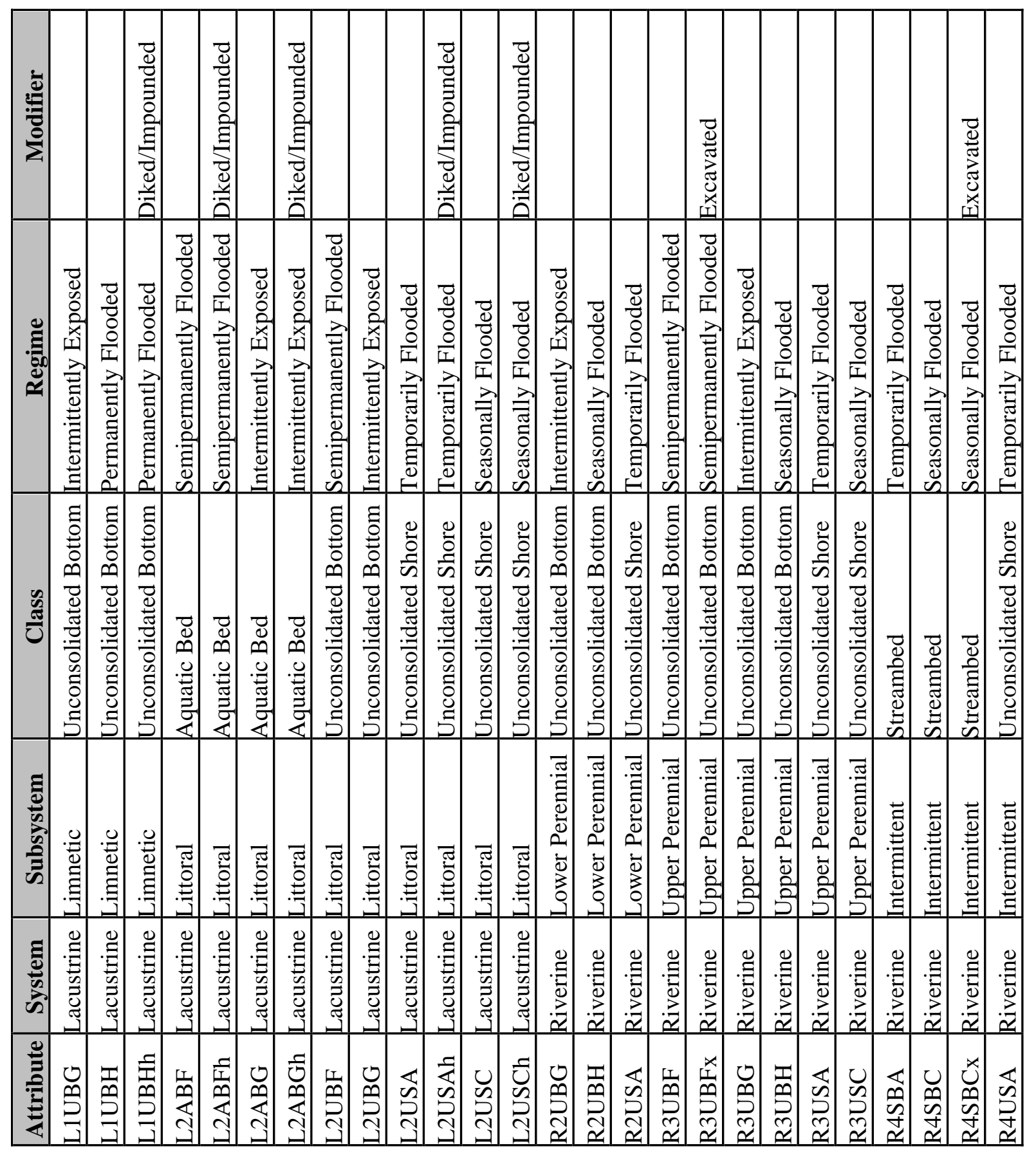



APPENDIX D. SCORING PROCECDURE FOR CALCULATING STRESSOR IMPACT RATING (SENSU FABER-LANGENDOEN ET AL. 2011) 

Table D-1. Stressor impact ratings calculations.

\begin{tabular}{llllllll}
\hline & \multicolumn{8}{c}{ Scope } \\
\hline \multirow{3}{*}{ Severity } & Extreme & Pervasive & Large & Restricted & Moderate & Small & Nil \\
& Serious & High & High & Medium & Medium & Low & Low \\
& Moderate & Medium & Medium & Low & Low & Low & Low \\
& Slight & Low & Low & Low & Low & Low & Low \\
\hline
\end{tabular}

Table D-2. Stressor impact rating numerical conversions.

\begin{tabular}{|c|c|c|c|c|c|c|c|}
\hline & & \multicolumn{6}{|c|}{ Scope } \\
\hline \multirow{5}{*}{ Severity } & & 5 & 4 & 3 & 2 & 1 & O \\
\hline & 4 & 20 & 16 & 12 & 8 & 4 & 0 \\
\hline & 3 & 15 & 12 & 9 & 6 & 3 & 0 \\
\hline & 2 & 10 & 8 & 6 & 4 & 2 & 0 \\
\hline & 1 & 5 & 4 & 3 & 2 & 1 & 0 \\
\hline
\end{tabular}

Table D-3. Rollup procedure for calculating an overall stressor impact rating.

Impact Values of Stressor Categories Overall Stressor Rating

1 or more Very High Stressors, OR 2 or more

High, OR 1 High +2 or more Medium

1 High Stressor, OR 3 or more Medium, OR 2

Very High (1)

Medium +2 or more Low, OR 1 Medium, +3 or more Low

1 Medium Stressor +5 or more Low, OR 8 or more Low

1 Medium Stressor + 1-4 Low, OR 1-7 Low

Stressors

High (2)

0 Stressors

Medium (3)

Low (4)

Absent (0) 

Appendix E. Scoring formulas for LeVel 2 attribute AND OVERALL WETLAND CONDITION SCORES 

1. For each metric, convert narrative rating score (1, 2, 3, 4, and 5$)$ into the corresponding metric score: $1=12,2=9,3=6,4=3$, and $5=1$.If metric has only four narrative ratings, then $1=12,2=9,3=6,4=3$. If metric had only three narrative ratings, then $1=12,2=6$, and $3=1$.

2. Each final attribute score was calculated according to the following:

Landscape Context (LC) Attribute Score:

Raw score $=[(($ Buffer Condition_Plants + Buffer Condition_Soils + Buffer Condition_Trash $) / 3) \mathrm{x}$ (Buffer width x Buffer length) $\left.{ }^{1 / 2}\right]^{1 / 2}+$ Landscape Connectivity

Final Attribute score $=$

Raw Landscape Context Score $\mathrm{x} 100$

Total possible points allowed (24)

Vegetation Attribute Score:

Raw score $=[(($ Invasive native + Native + Noxious $) / 3)+$ Litter or woody debris accumulation + Patch Interspersion + ((Woody vegetation $)+$ Browse $) / 2)]$

Final Attribute Score $=$

Raw Biotic Score $\mathrm{x} 100$

Total possible points allowed (48)

Physicochemical Attribute Score:

Raw score $=[$ Soil Surface Integrity $+(($ Water Quality_Algae + Water Quality_Plants + Water Quality_Turbidity)/3)]

Final Attribute Score = Raw Physicochemical Score $\mathrm{x} 100$

Total possible points allowed (24)

Hydrology Attribute Score:

Raw score $=[($ Hydrologic Input + Hydrologic Output $) / 2)+$ Hydroperiod + Surface Water Connectivity scores

Final Attribute Score $=$

Raw Hydrology Score x 100

Total possible points allowed (36)

3. Final AA Score:

Final LC + Final Vegetation + Final Physico + Final Hydro/4 

Appendix F. Terminology, description, and calculation of THE FLORISTIC QUALITY ASSESSMENT METRICS 

$N_{n}=$ count of native species, $N_{a}=$ count of all species, $N_{e}=$ count of non-native species, $C_{i}=$ index of conservatism for the $i^{\text {th }}$ species, $x_{i}=$ percent cover for the $i^{\text {th }}$ species.

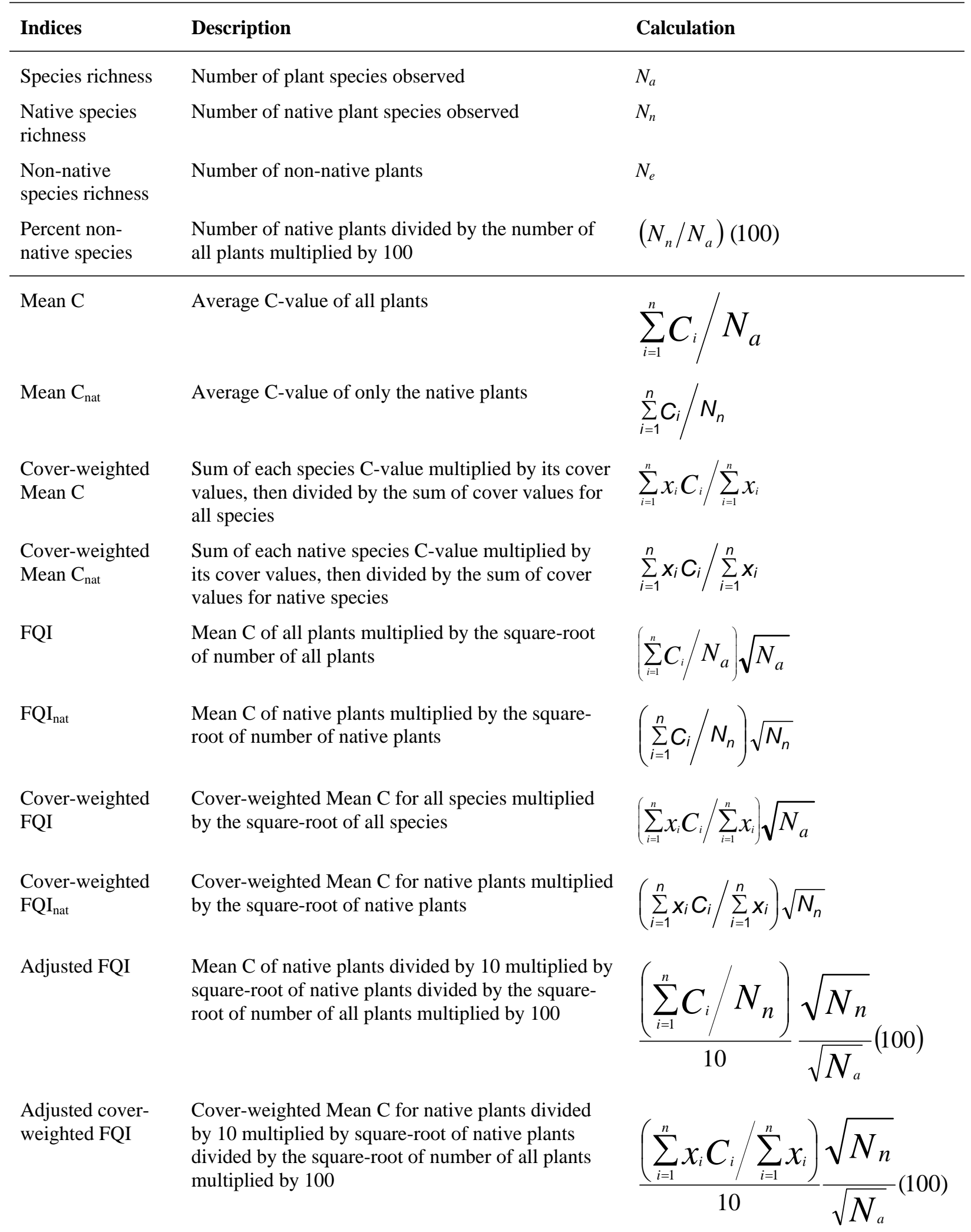



Appendix G. WeTland landscape PROFILE FOR PALUSTRINe WETLANDS IN THE SOUTHWEST MONTANA BASIN-WIDE ASSESSMENT PROJECT AREA 



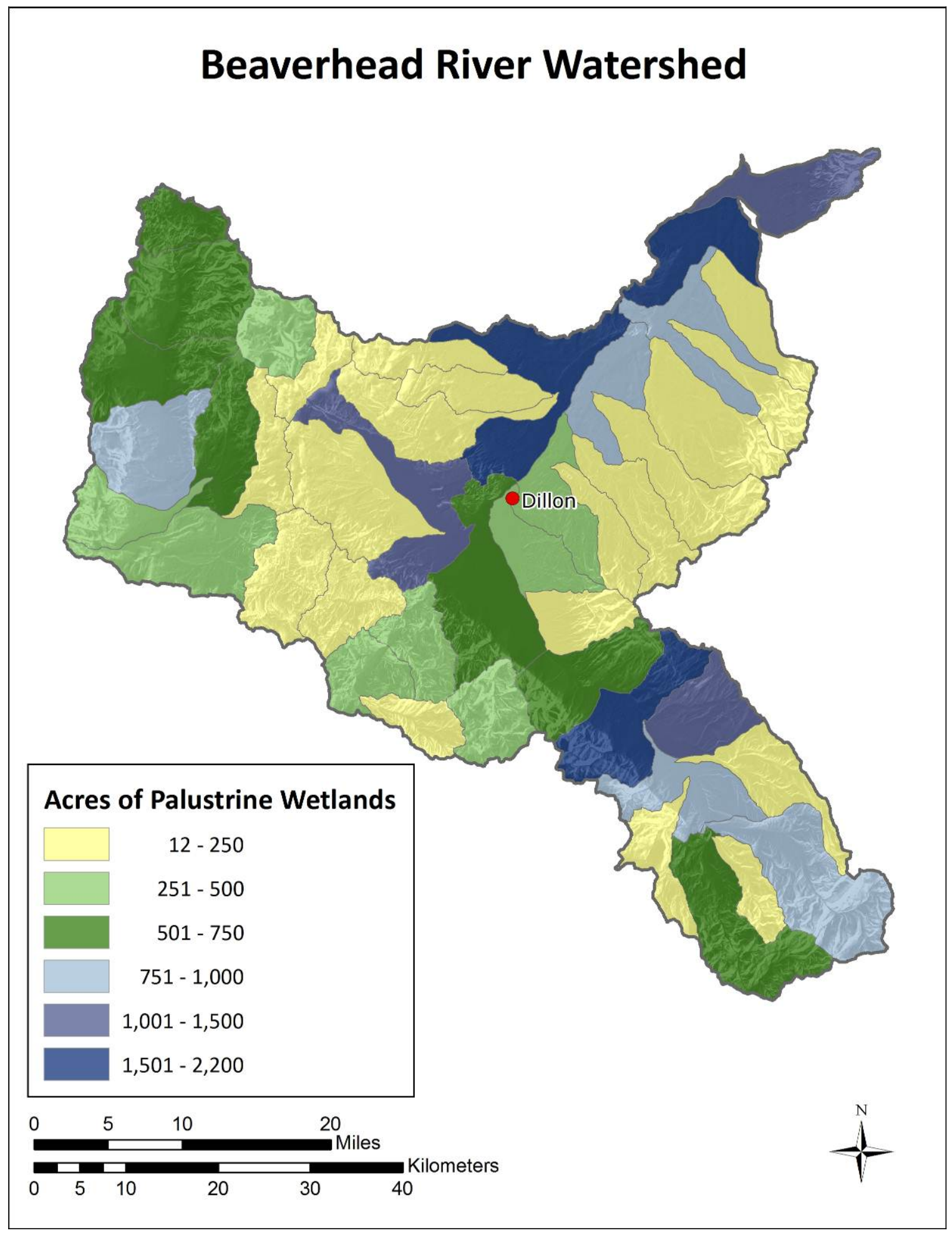

Figure G-1. Acres of palustrine wetland by sixth code hydrologic unit in the Beaverhead River watershed. 


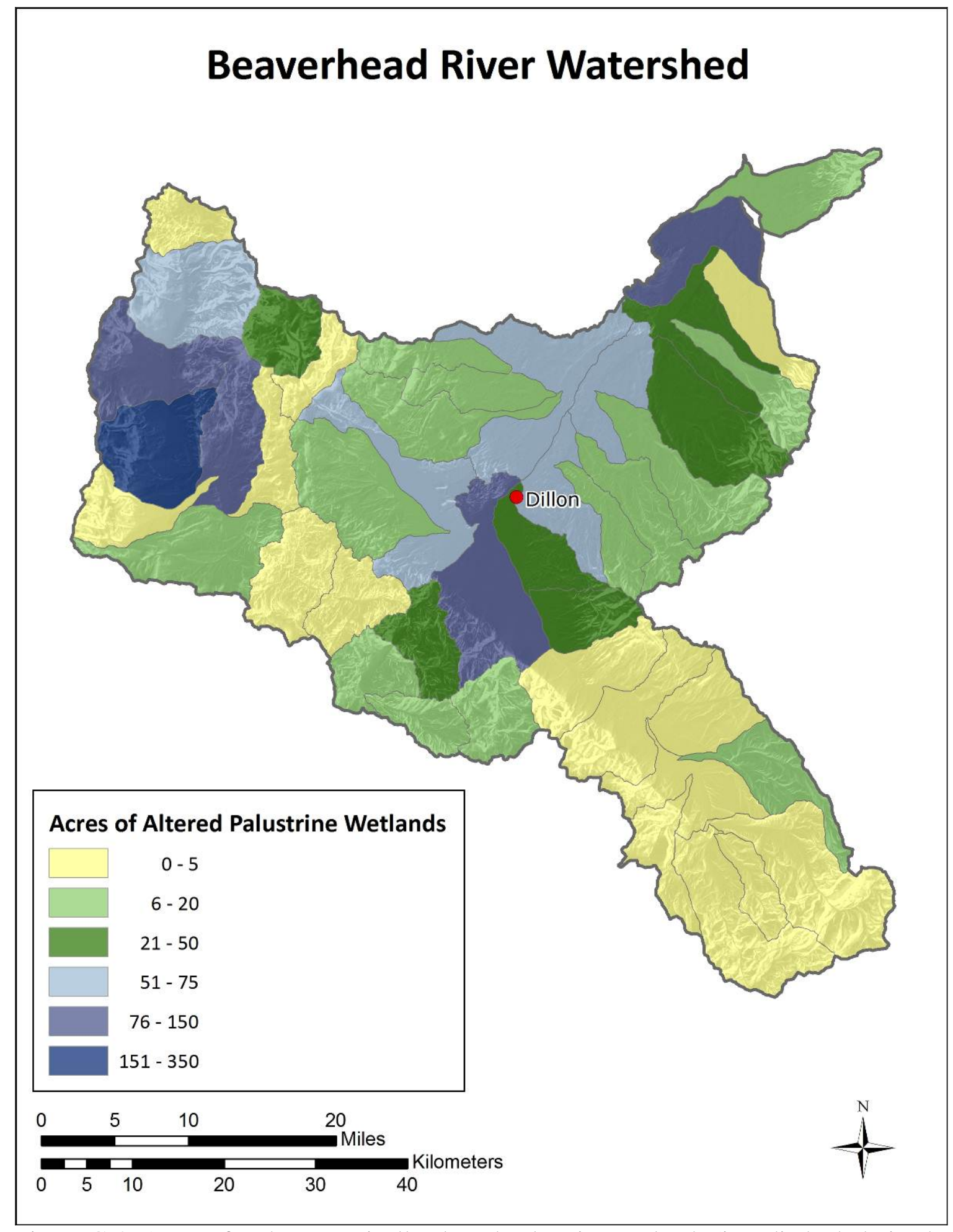

Figure G-2. Acres of anthropogenically altered palustrine wetlands (i.e., ditched, drained, impounded, excavated, farmed) by sixth code hydrologic unit in the Beaverhead River watershed. 


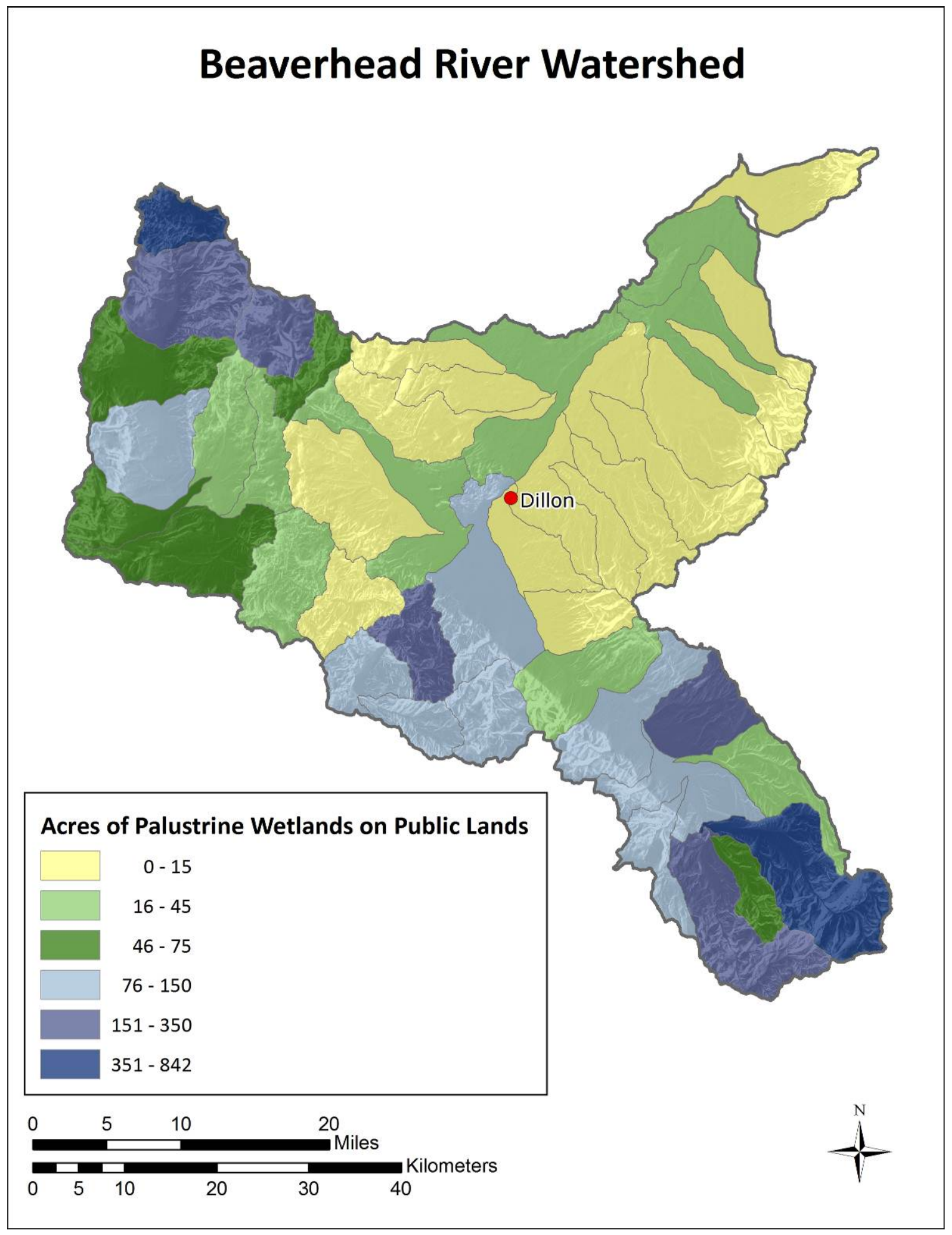

Figure G-3. Acres of palustrine wetlands on publicly owned lands by sixth code hydrologic unit in the Beaverhead River watershed. 


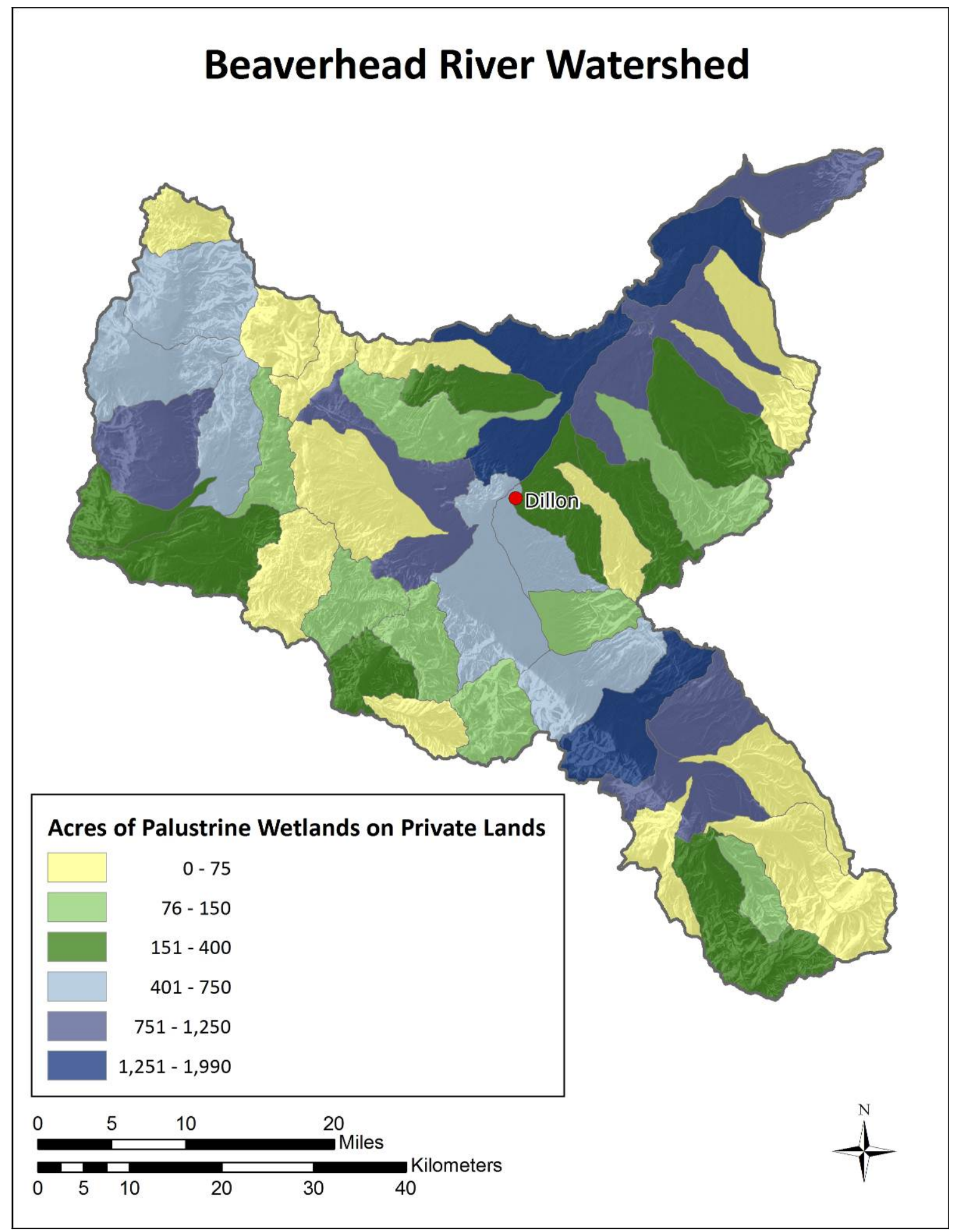

Figure G-4. Acres of palustrine wetlands on privately owned lands by sixth code hydrologic unit in the Beaverhead River watershed. 


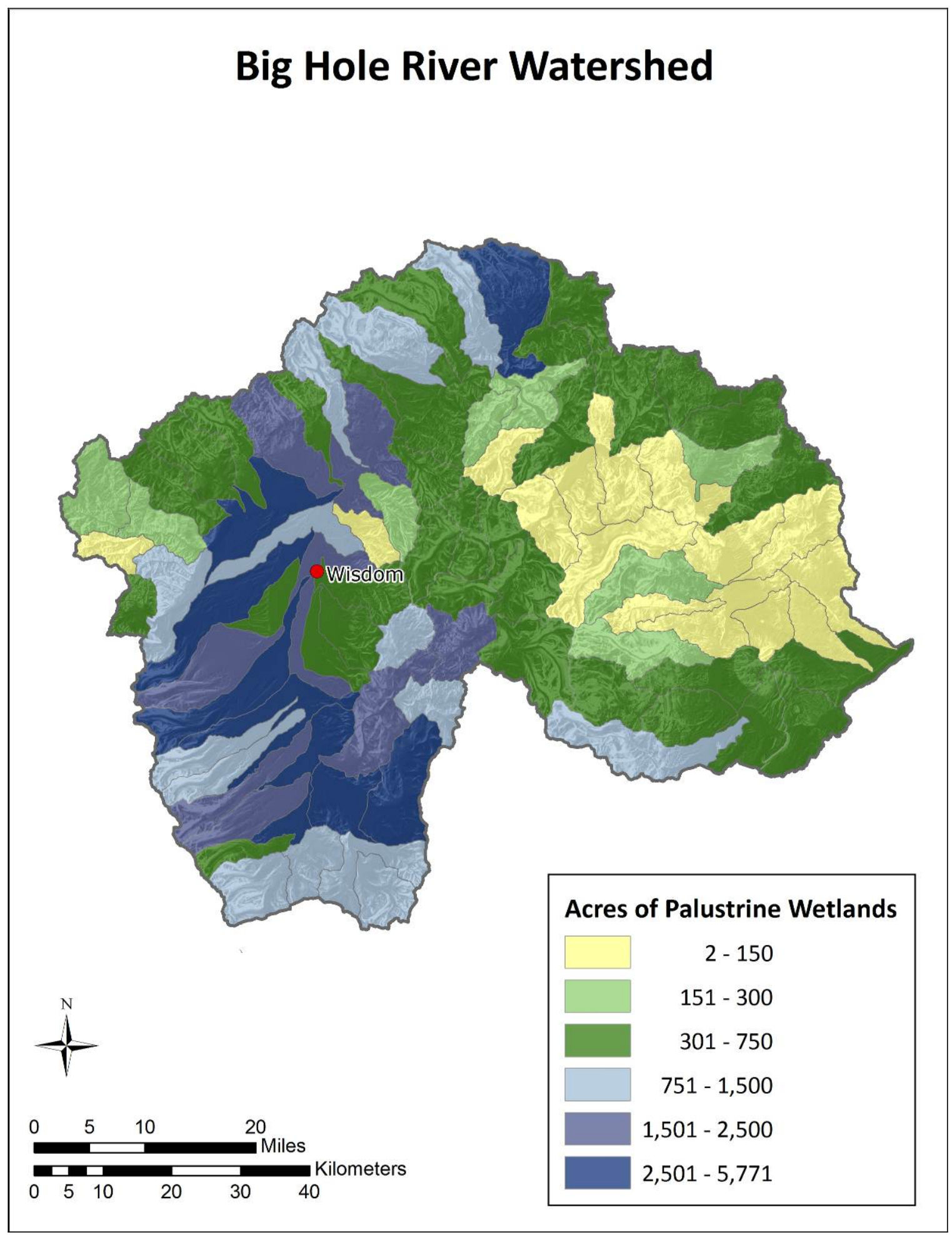

Figure G-5. Acres of palustrine wetland by sixth code hydrologic unit in the Big Hole River watershed. 


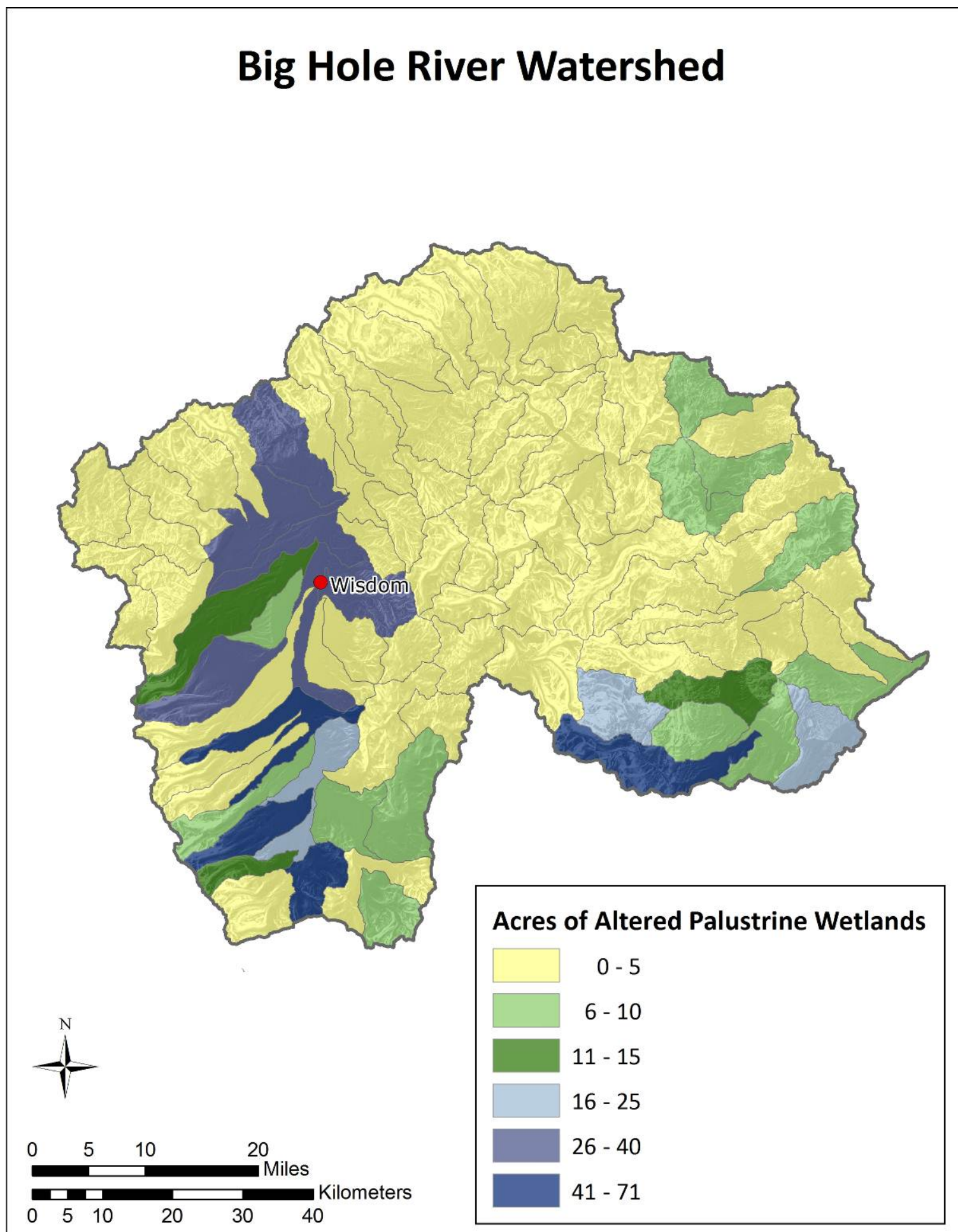

Figure G-6. Acres of anthropogenically altered palustrine wetlands (i.e., ditched, drained, impounded, excavated, farmed) by sixth code hydrologic unit in the Big Hole River watershed. 


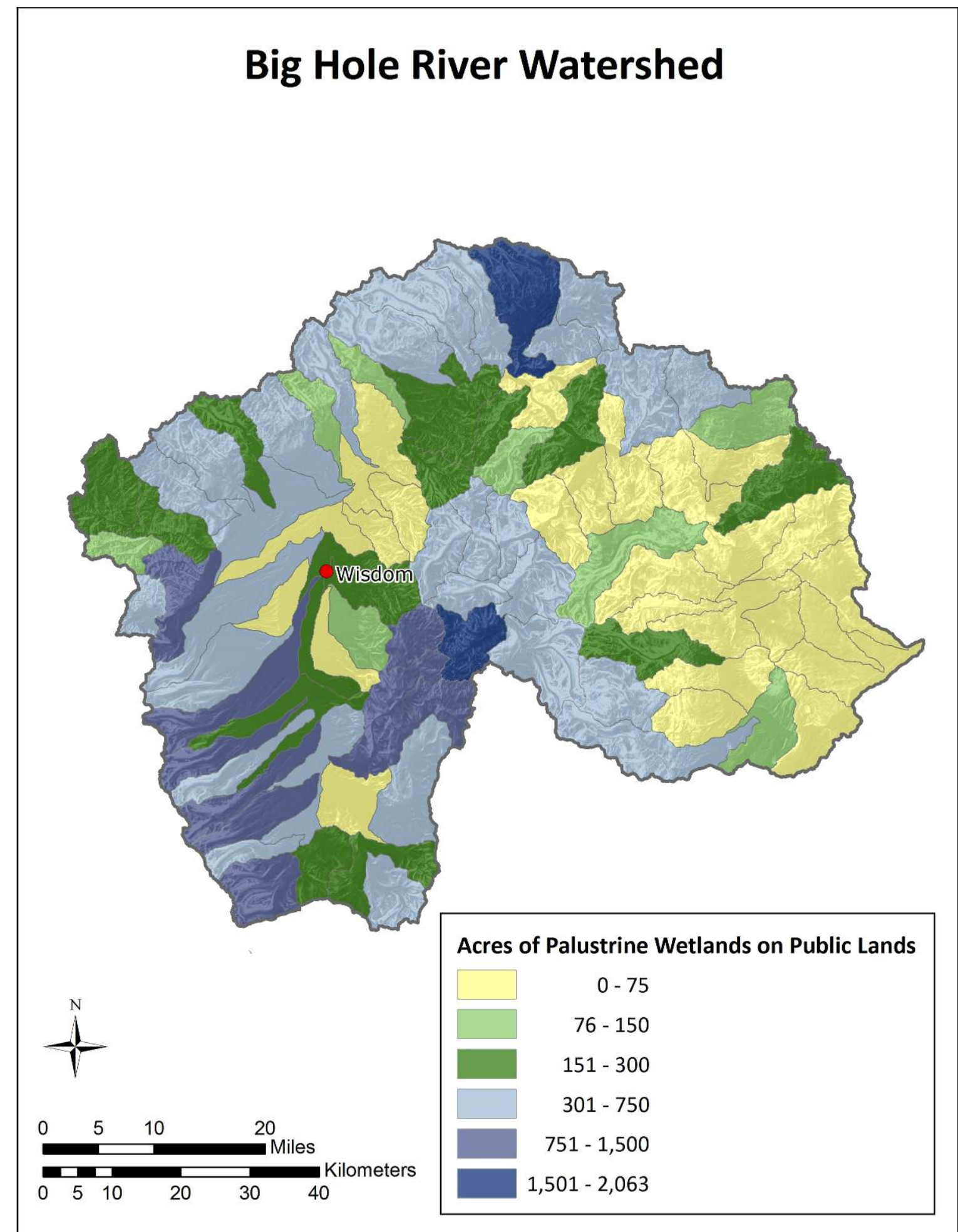

Figure G-7. Acres of palustrine wetlands on publicly owned lands by sixth code hydrologic unit in the Big Hole River watershed. 


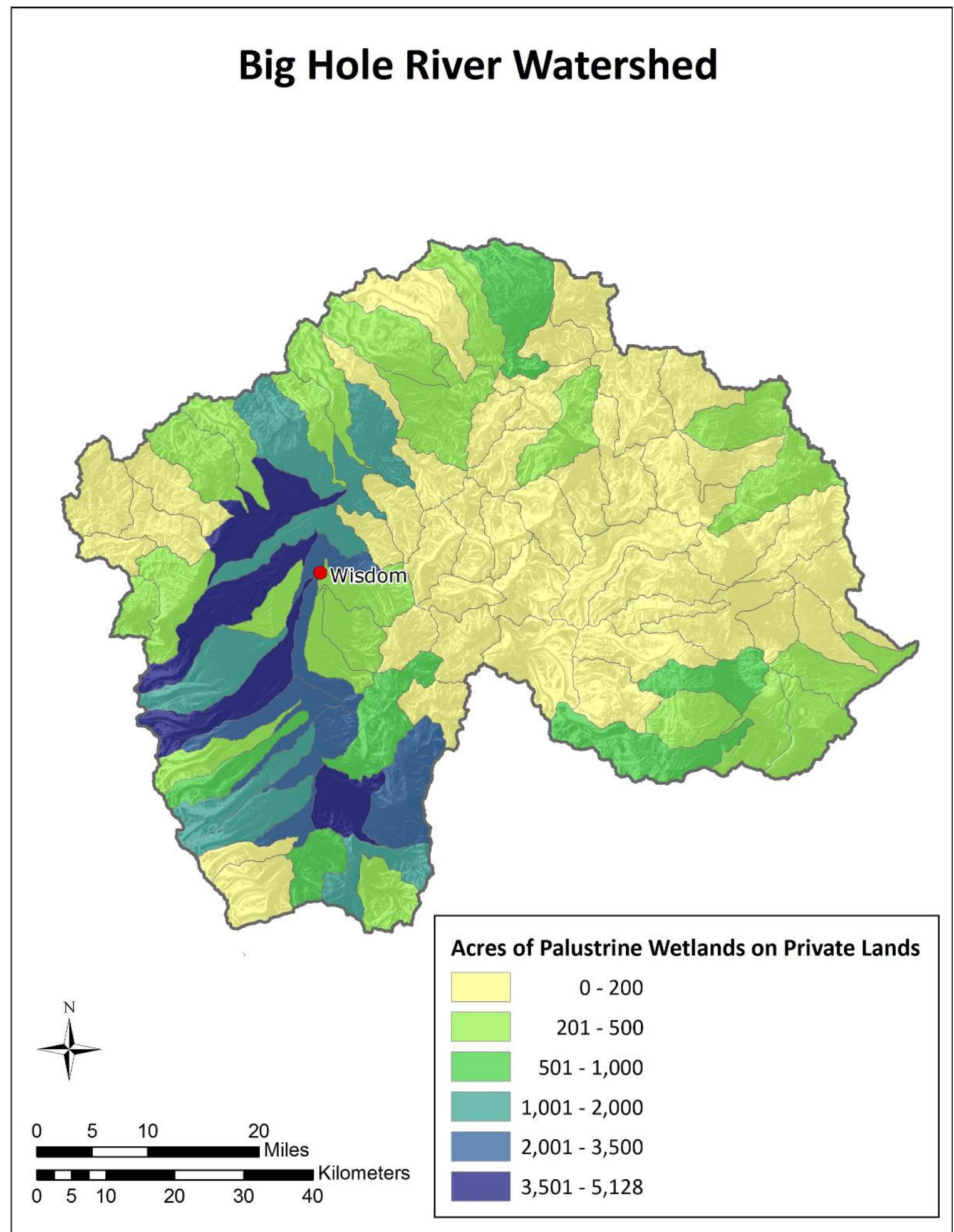

Figure G-8. Acres of palustrine wetlands on privately owned lands by sixth code hydrologic unit in the Big Hole River watershed. 


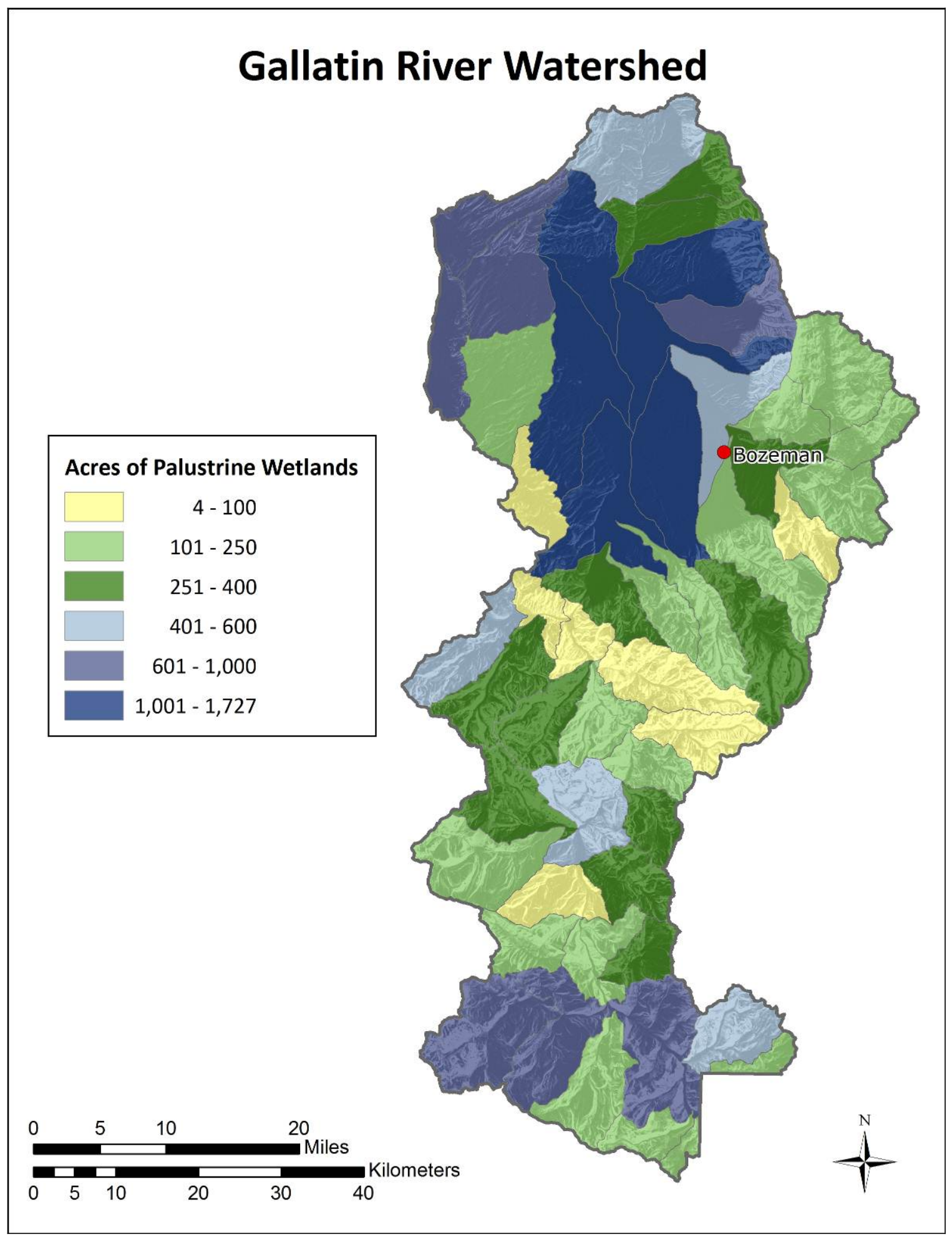

Figure G-9. Acres of palustrine wetland by sixth code hydrologic unit in the Gallatin River watershed. 


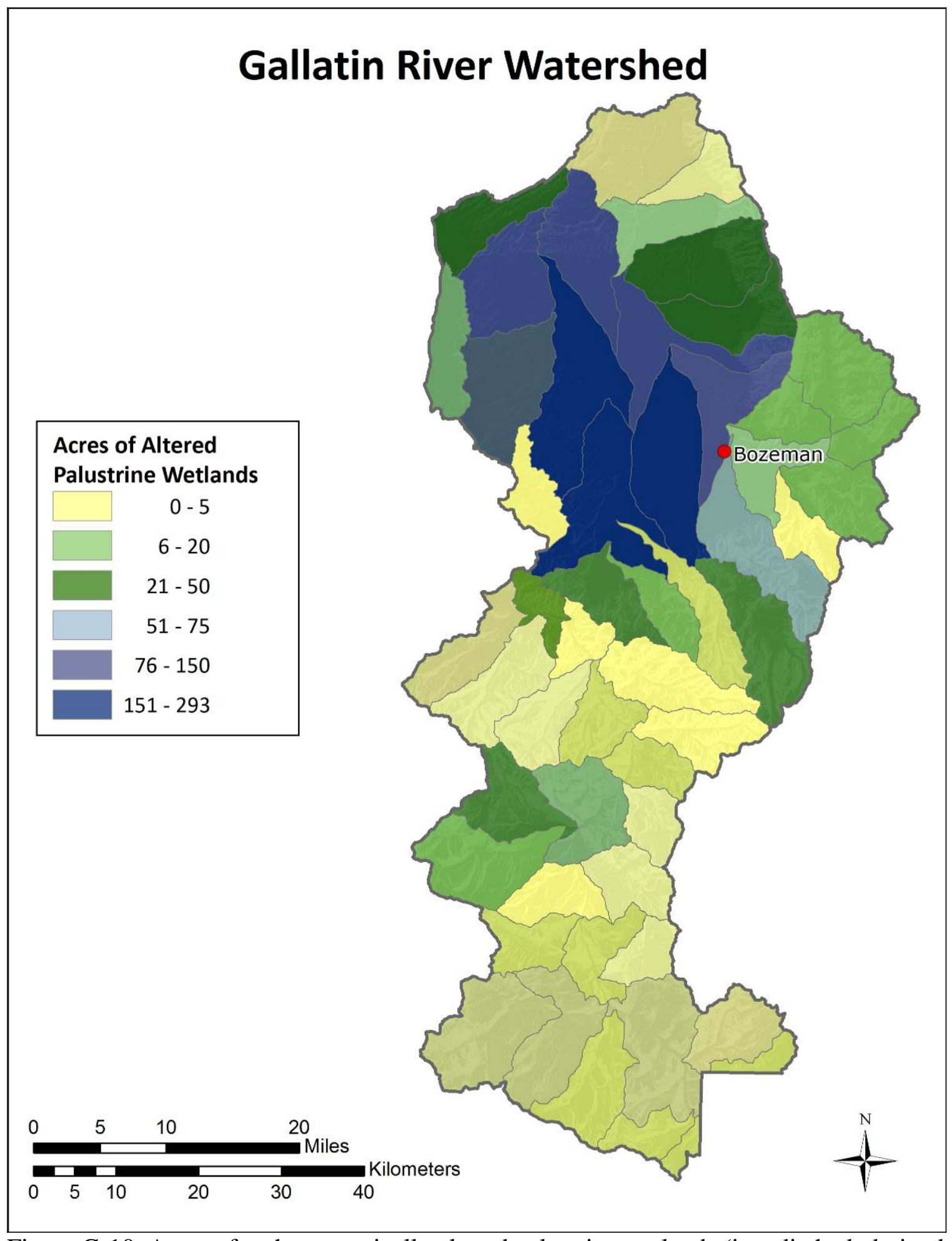

Figure G-10. Acres of anthropogenically altered palustrine wetlands (i.e., ditched, drained, impounded, excavated, farmed) by sixth code hydrologic unit in the Gallatin River watershed. 


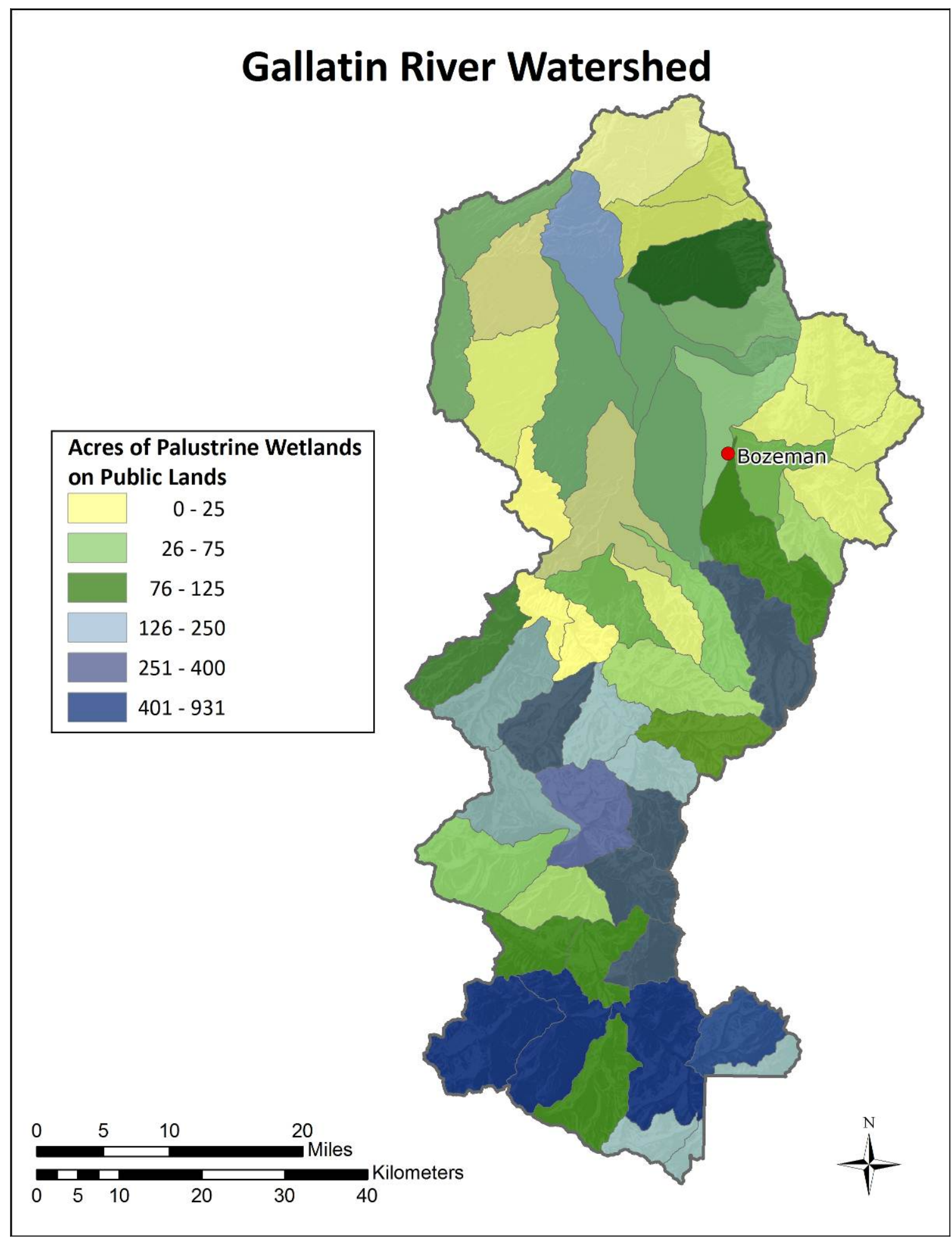

Figure G-11. Acres of palustrine wetlands on publicly owned lands by sixth code hydrologic unit in the Gallatin River watershed. 


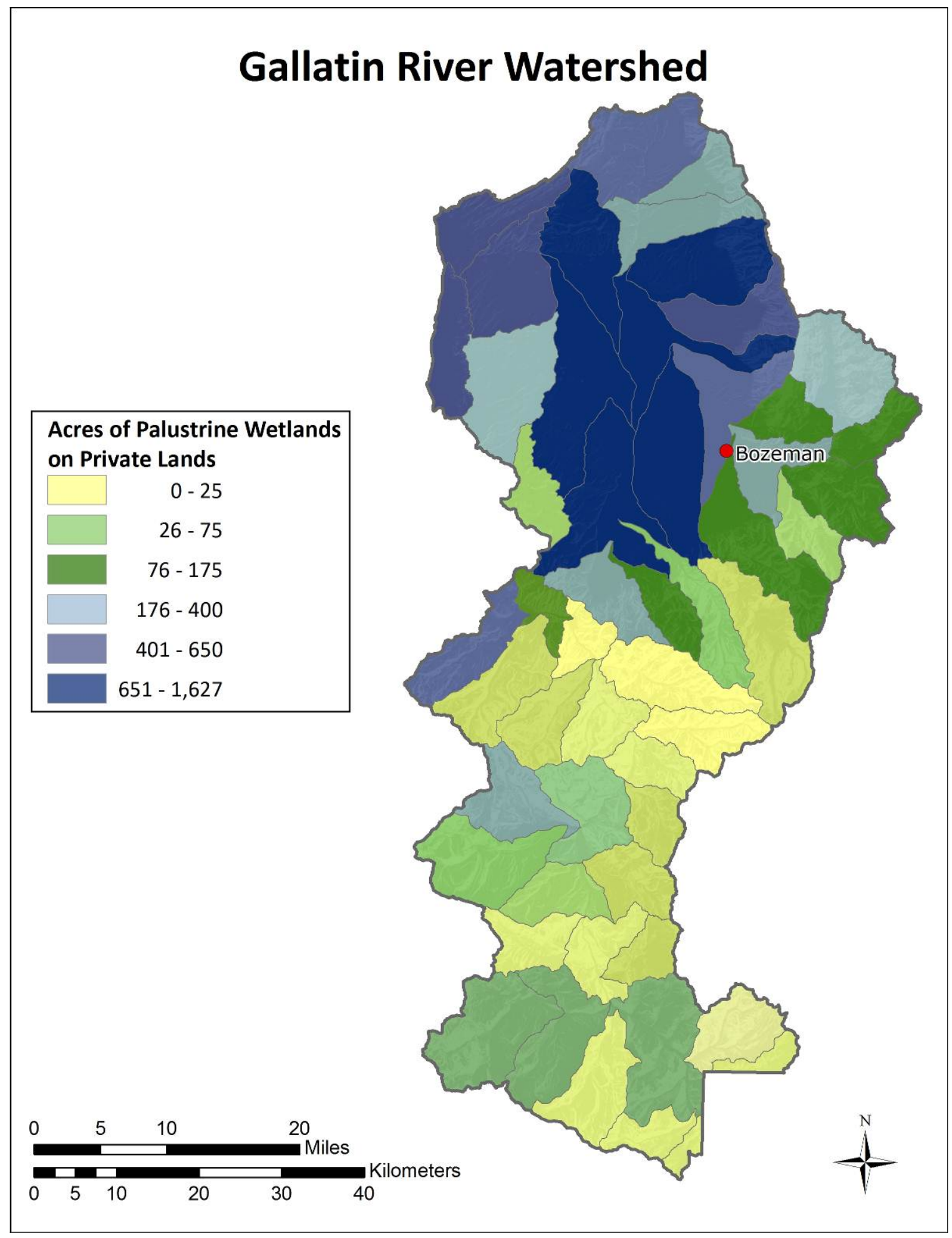

Figure G-12. Acres of palustrine wetlands on privately owned lands by sixth code hydrologic unit in the Gallatin River watershed. 


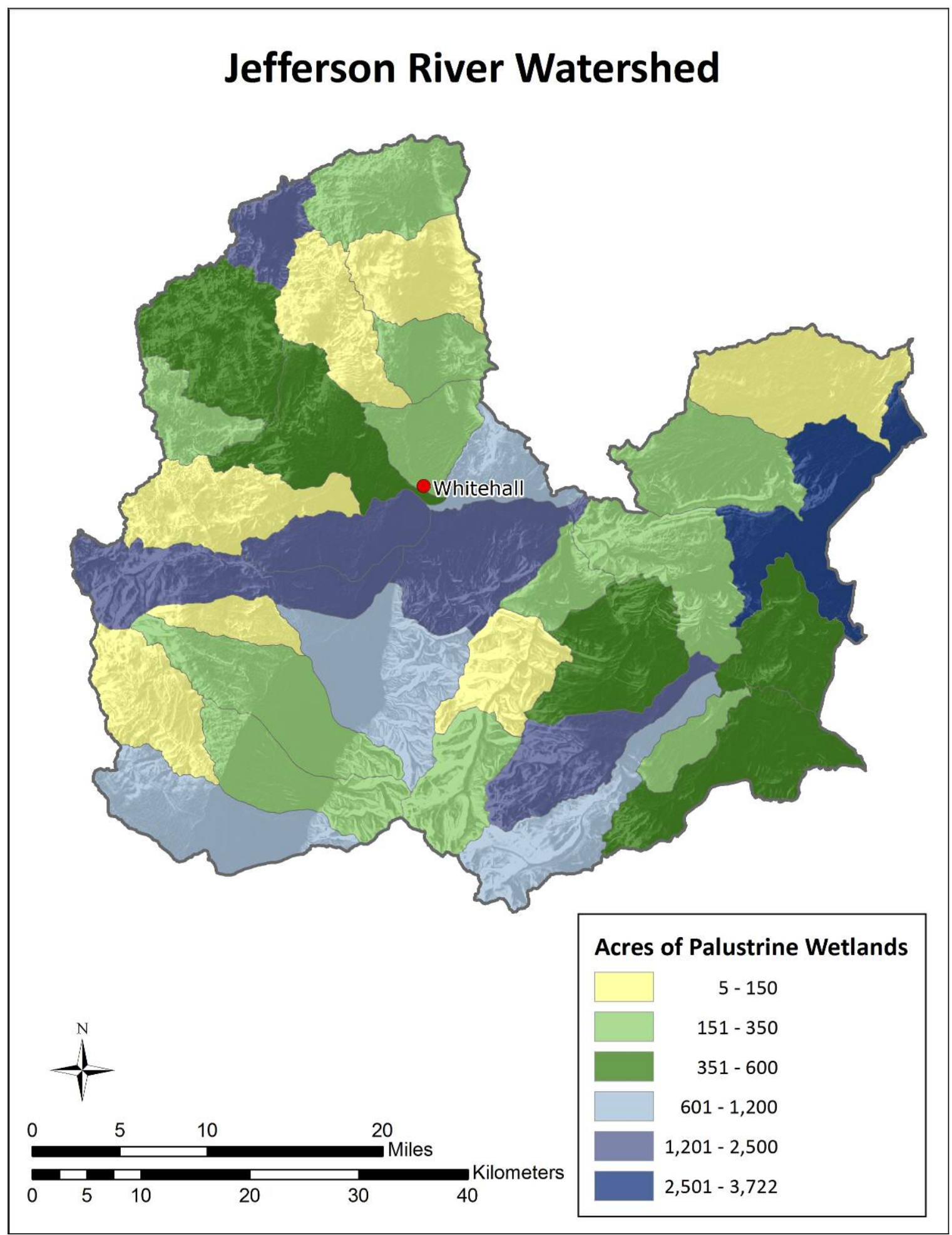

Figure G-13. Acres of palustrine wetland by sixth code hydrologic unit in the Jefferson River watershed. 


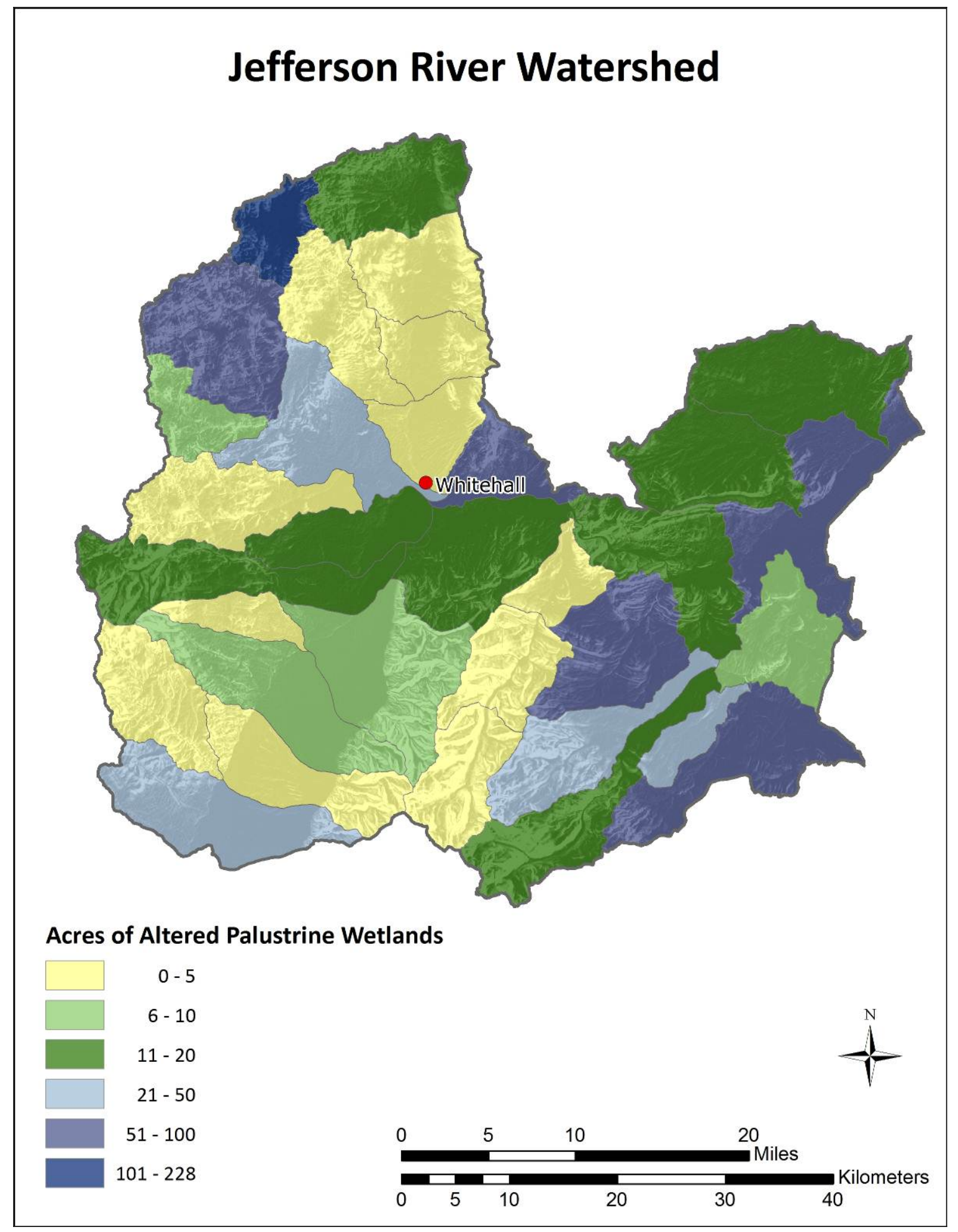

Figure G-14. Acres of anthropogenically altered palustrine wetlands (i.e., ditched, drained, impounded, excavated, farmed) by sixth code hydrologic unit in the Jefferson River watershed. 


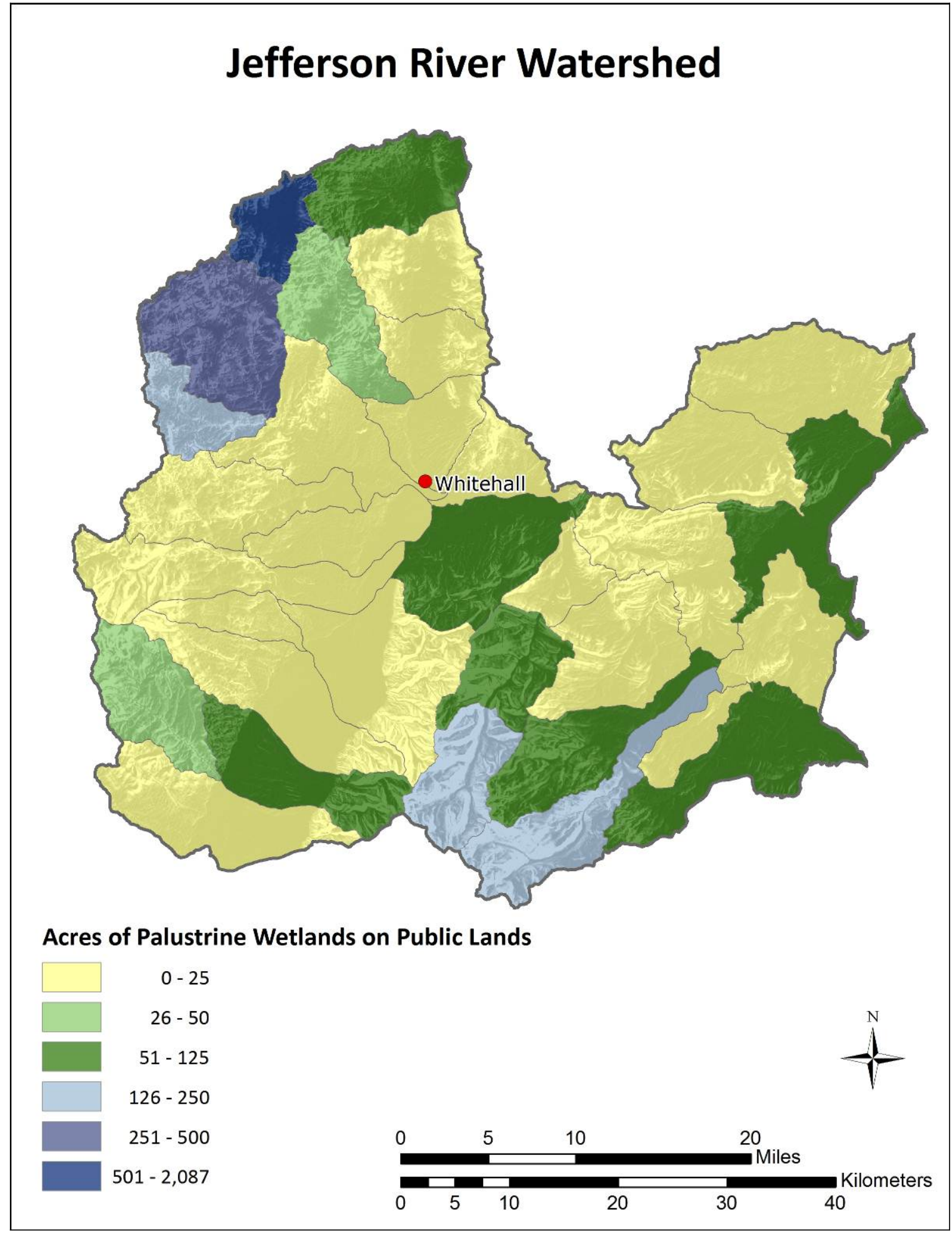

Figure G-15. Acres of palustrine wetlands on publicly owned lands by sixth code hydrologic unit in the Jefferson River watershed. 


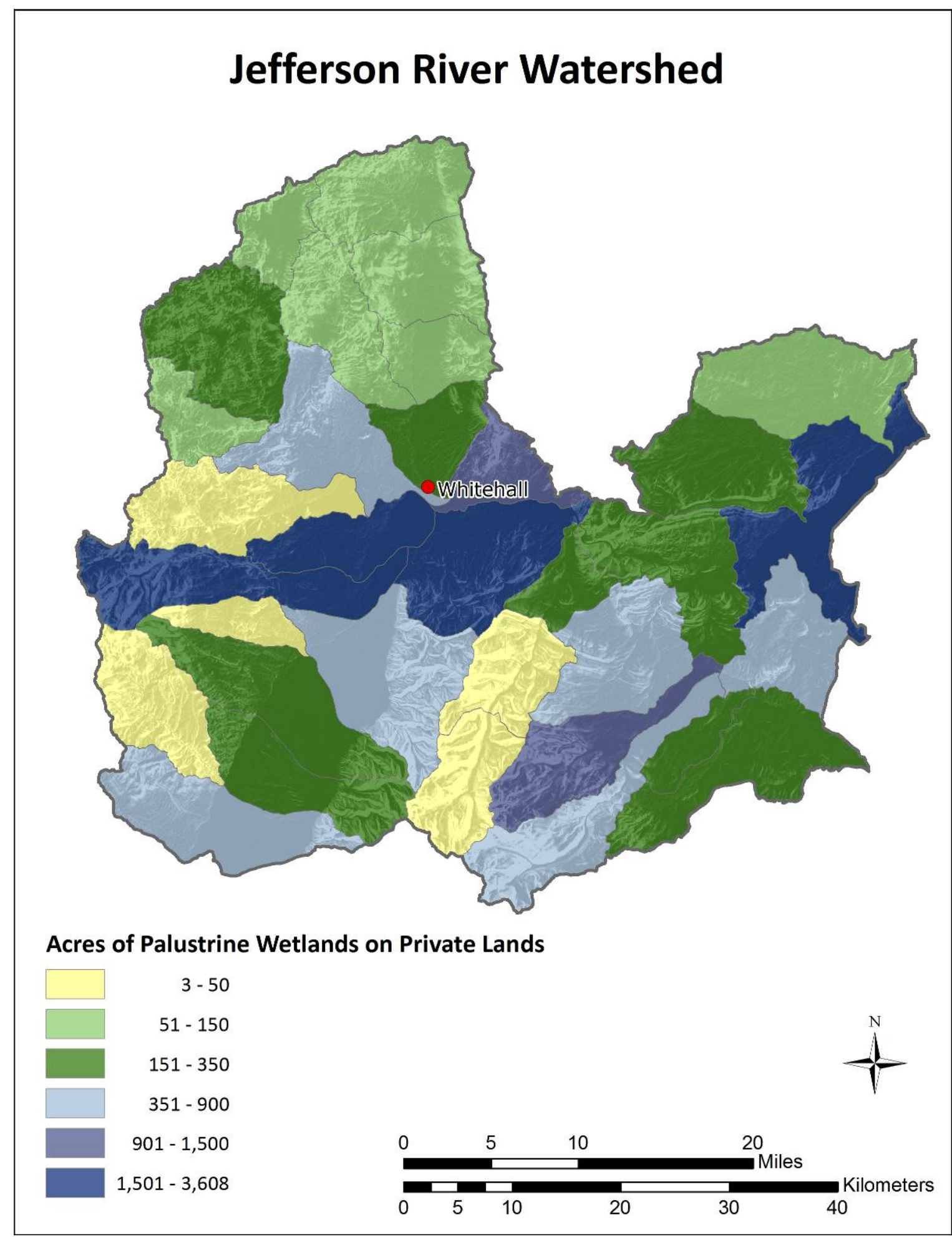

Figure G-16. Acres of palustrine wetlands on privately owned lands by sixth code hydrologic unit in the Jefferson River watershed. 


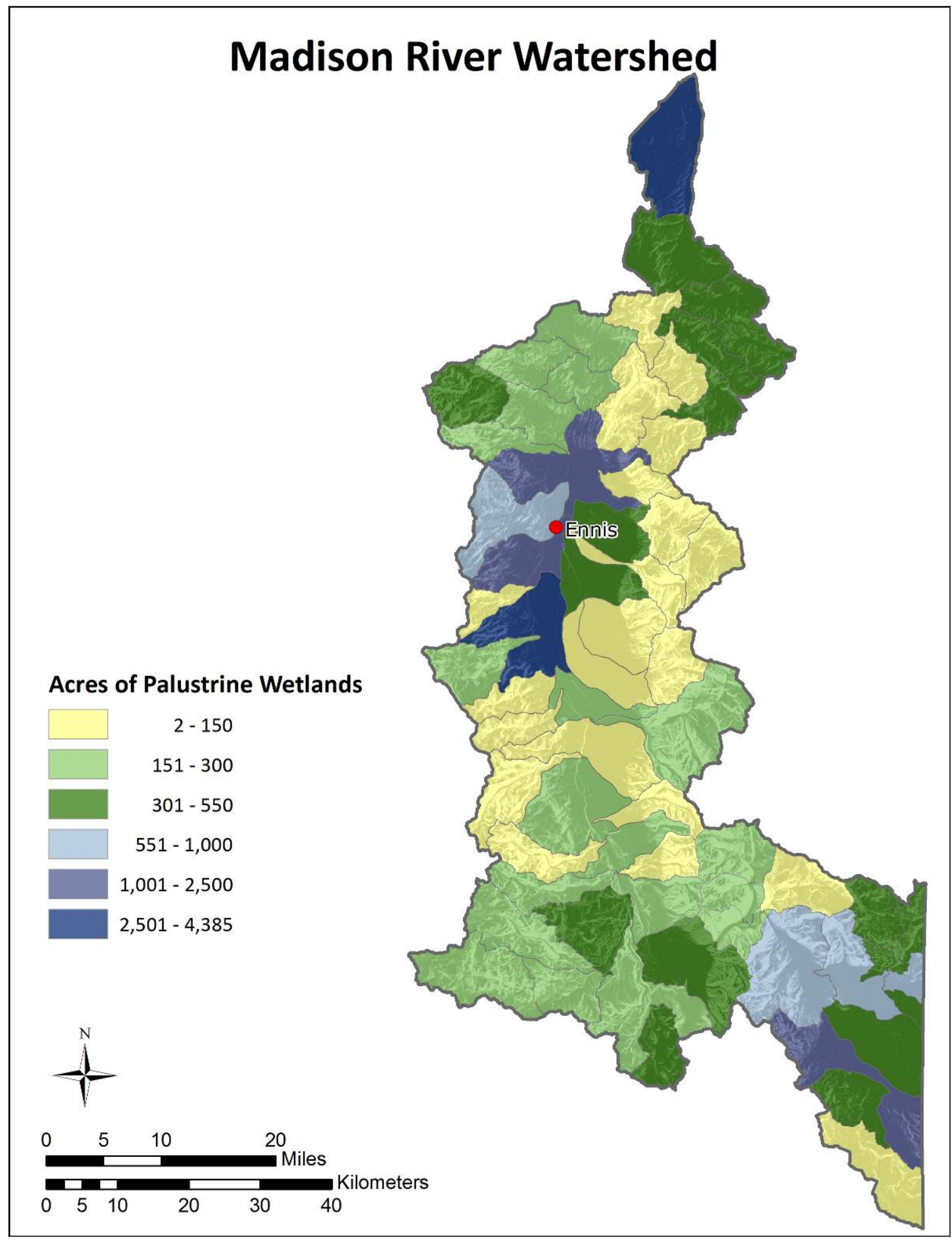

Figure G-17. Acres of palustrine wetland by sixth code hydrologic unit in the Madison River watershed. 


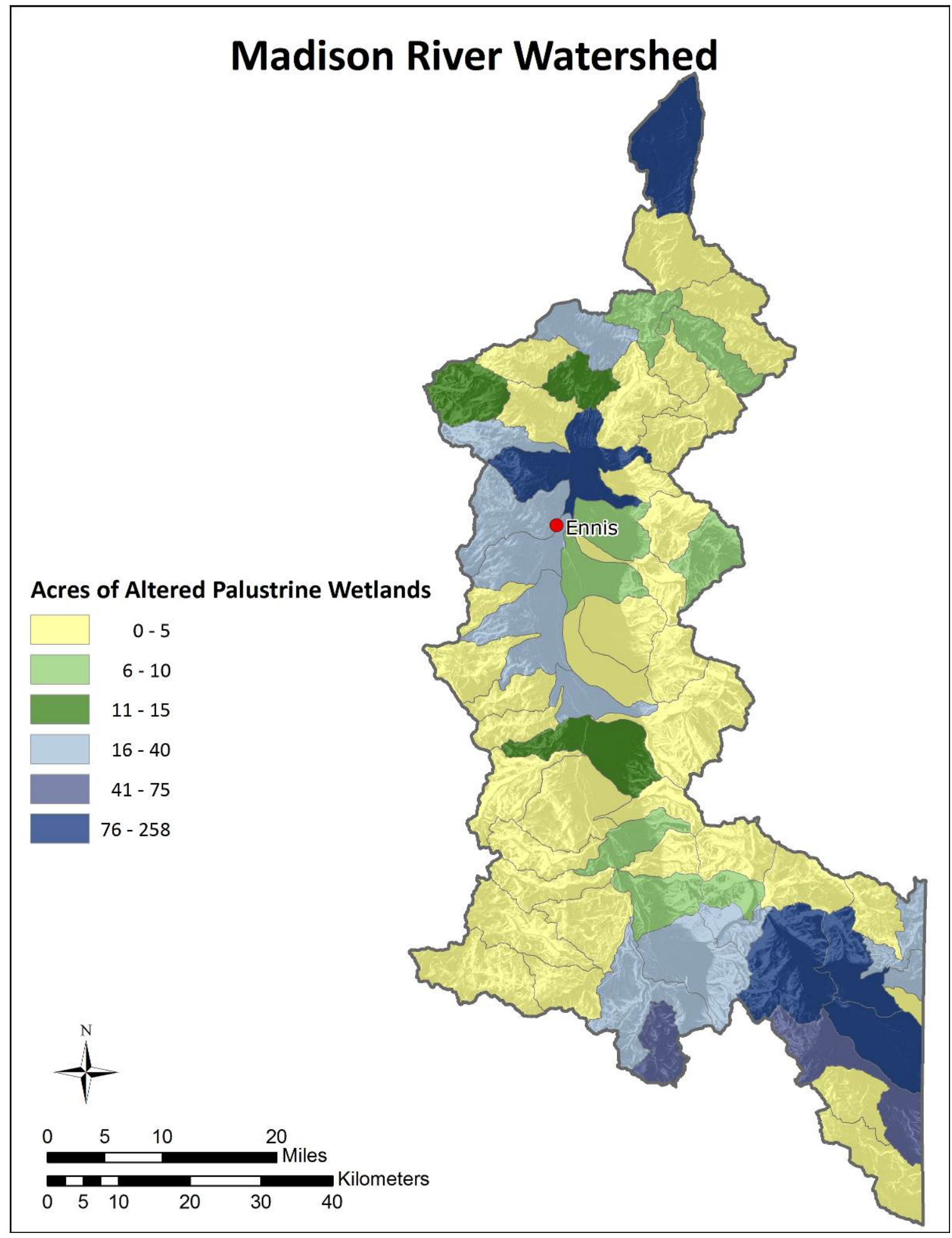

Figure G-18. Acres of anthropogenically altered palustrine wetlands (i.e., ditched, drained, impounded, excavated, farmed) by sixth code hydrologic unit in the Madison River watershed. 


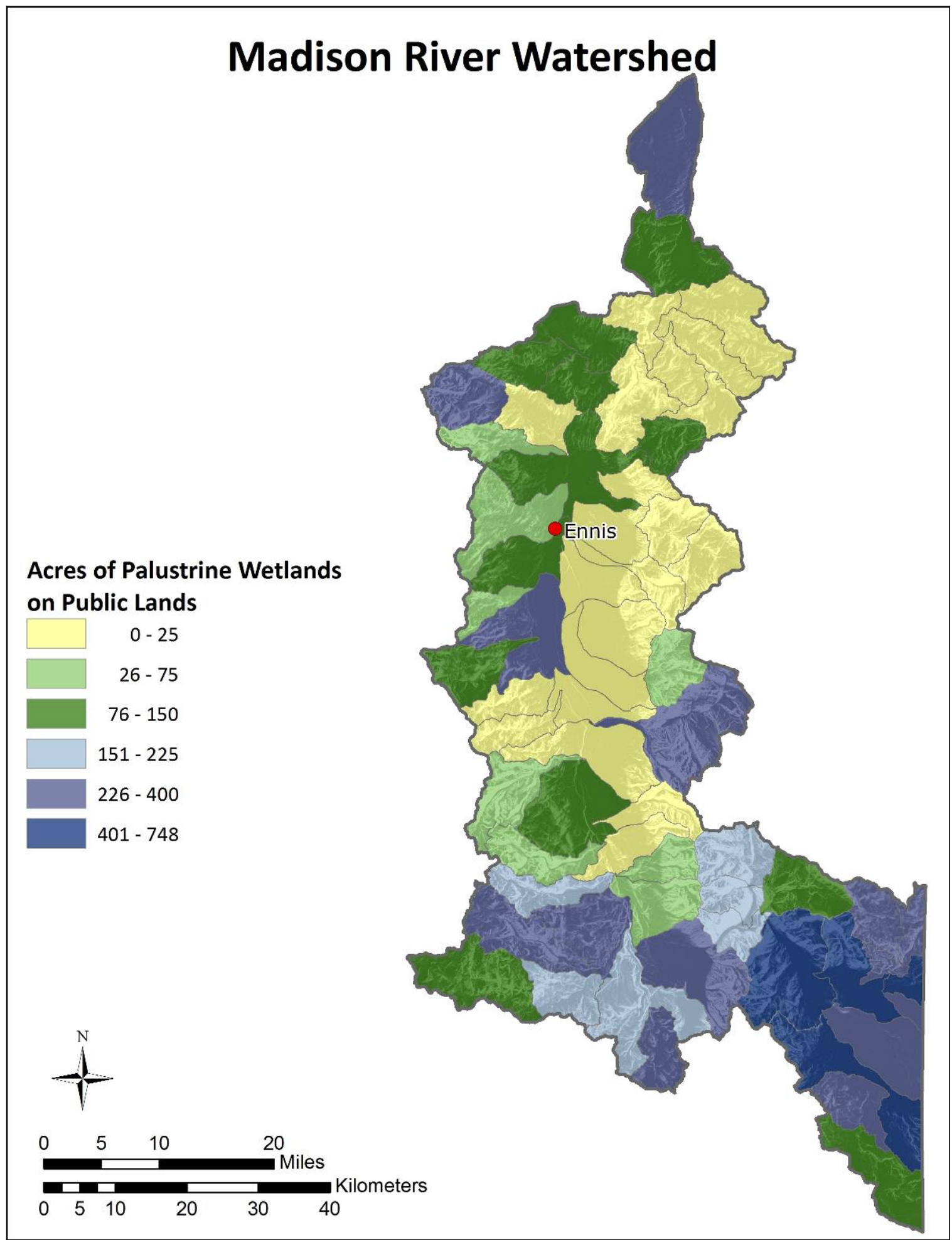

Figure G-19. Acres of palustrine wetlands on publicly owned lands by sixth code hydrologic unit in the Madison River watershed. 


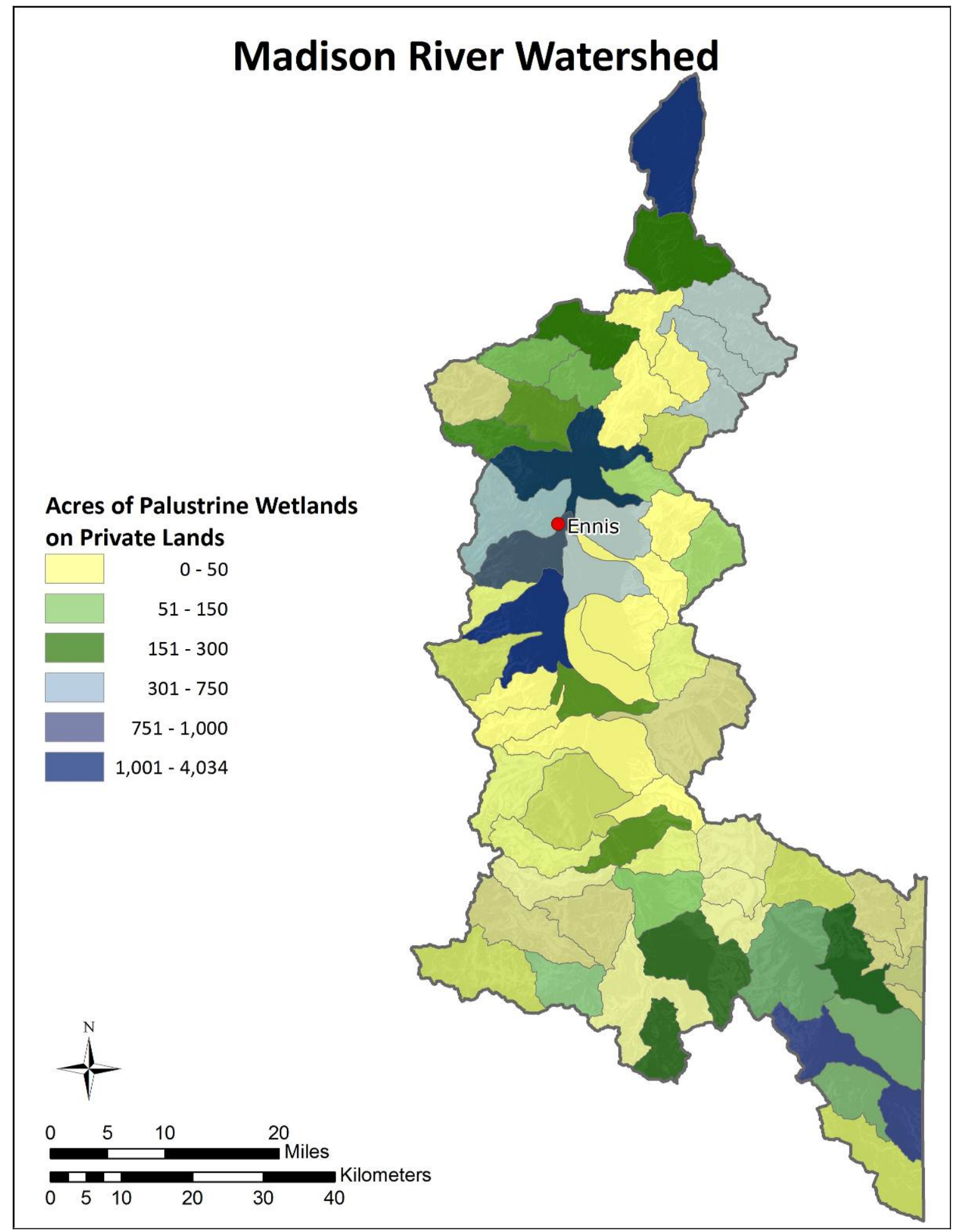

Figure G-20. Acres of palustrine wetlands on privately owned lands by sixth code hydrologic unit in the Madison River watershed. 


\section{Ruby River Watershed}

\section{Acres of Palustrine Wetlands}
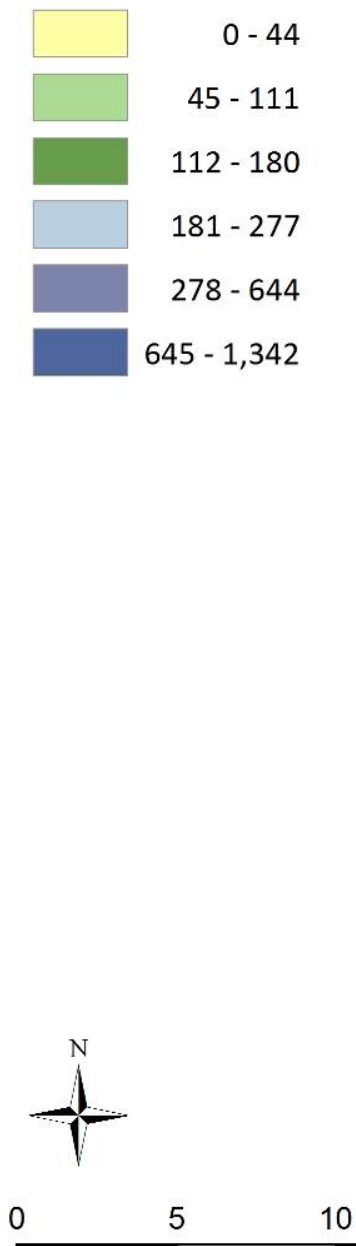

20

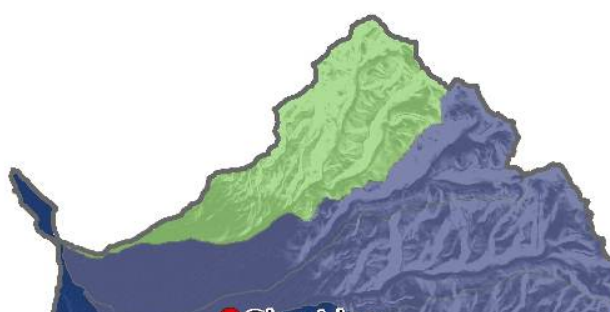

Sheridan

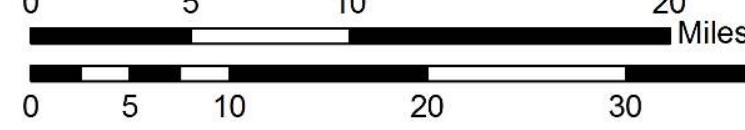

Kilometers

40

Figure G-21. Acres of palustrine wetland by sixth code hydrologic unit in the Ruby River watershed. 


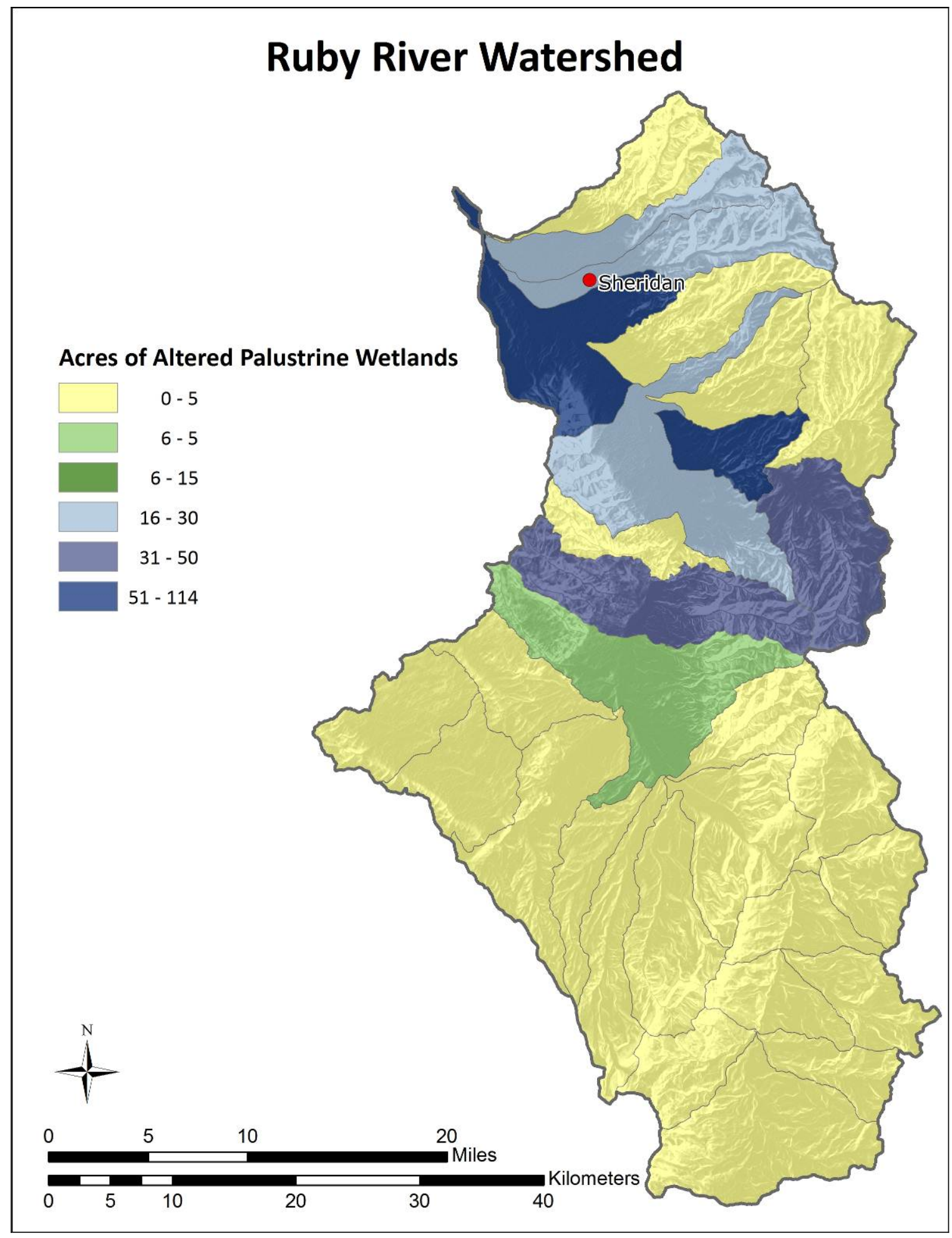

Figure G-22. Acres of anthropogenically altered palustrine wetlands (i.e., ditched, drained, impounded, excavated, farmed) by sixth code hydrologic unit in the Ruby River watershed. 


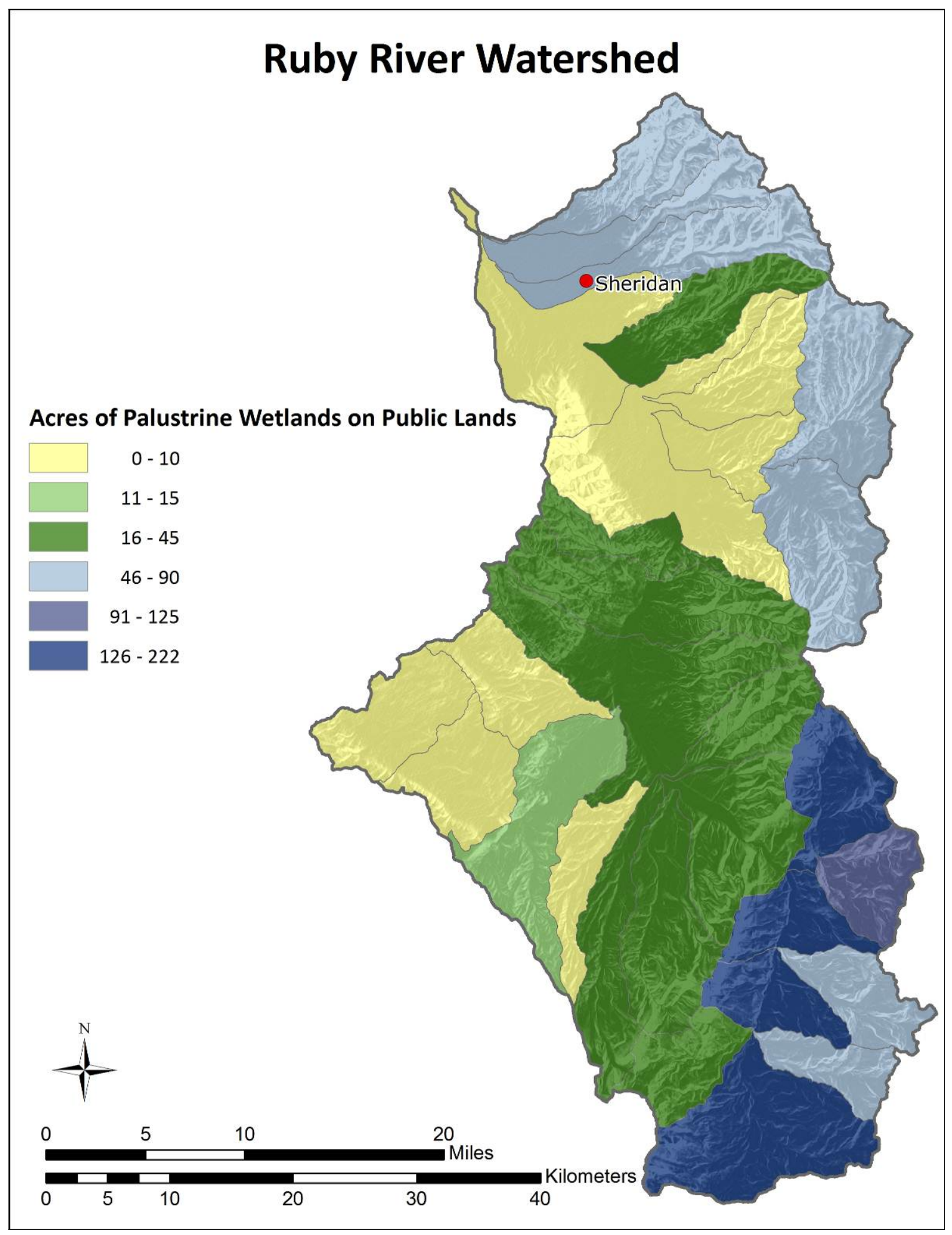

Figure G-23. Acres of palustrine wetlands on publicly owned lands by sixth code hydrologic unit in the Ruby River watershed. 


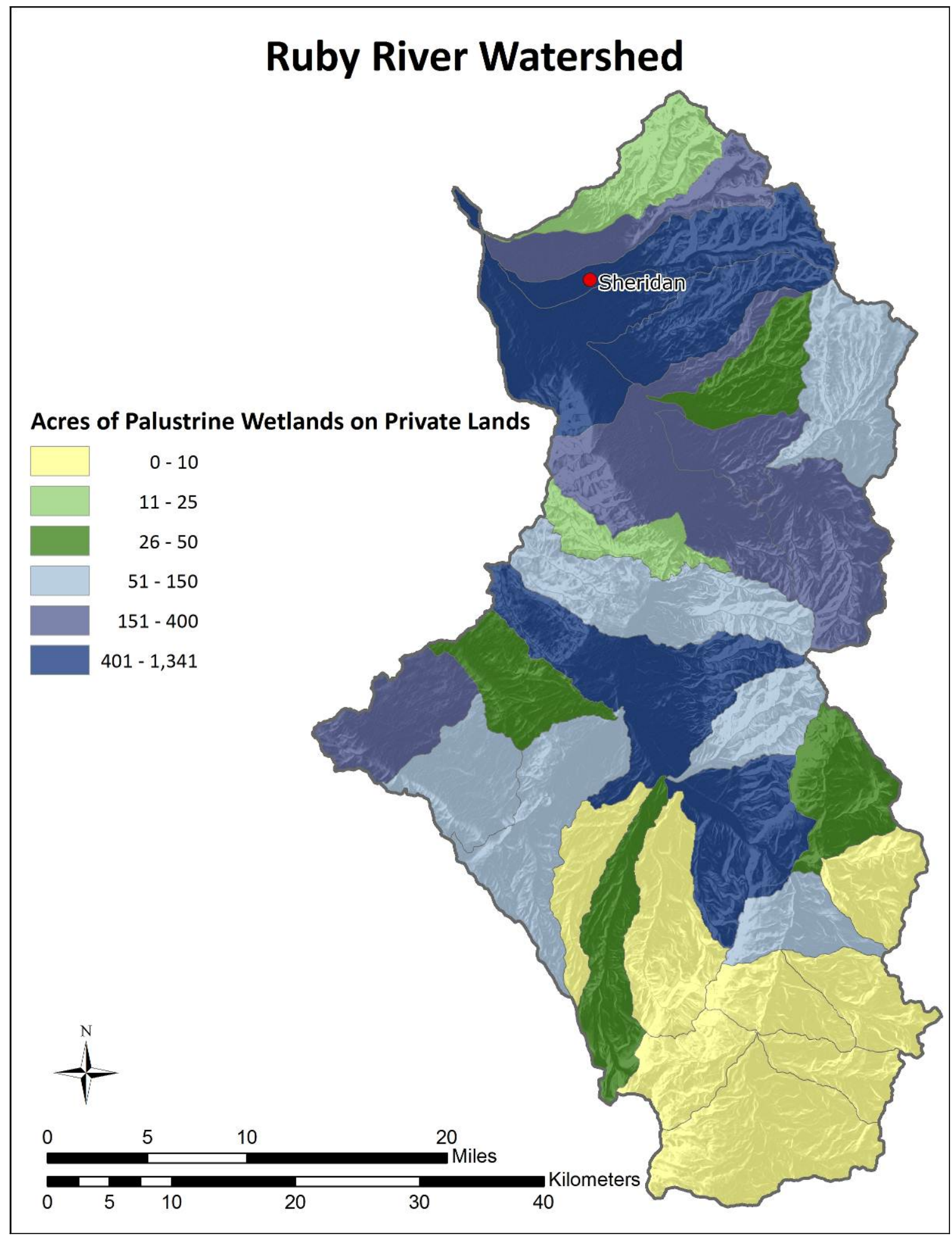

Figure G-24. Acres of palustrine wetlands on publicly owned lands by sixth code hydrologic unit in the Ruby River watershed. 


\section{Appendix H. Level 1 Assessment Summary}





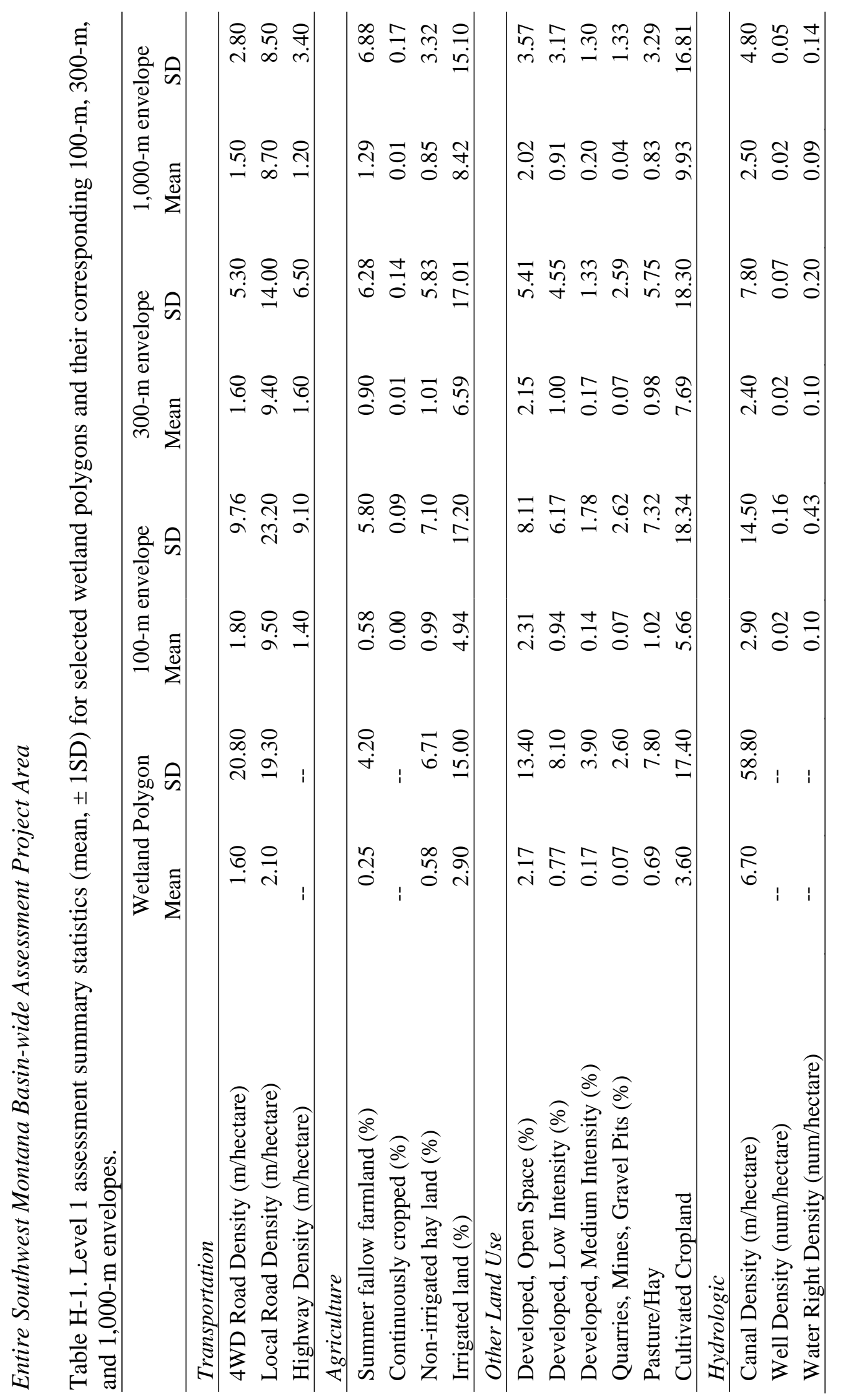

Appendix $H$ - 1 


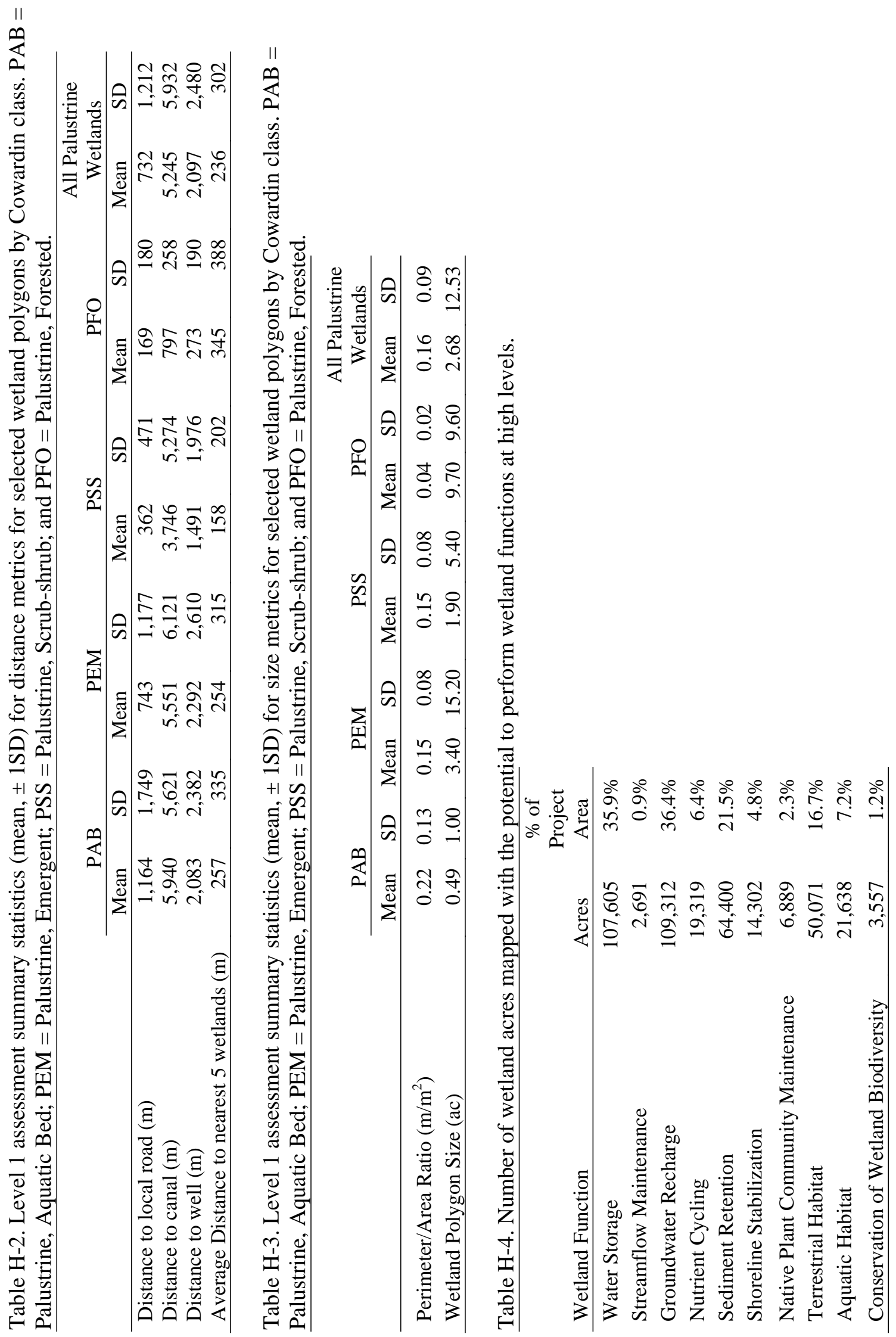

Appendix $\mathrm{H}-2$ 


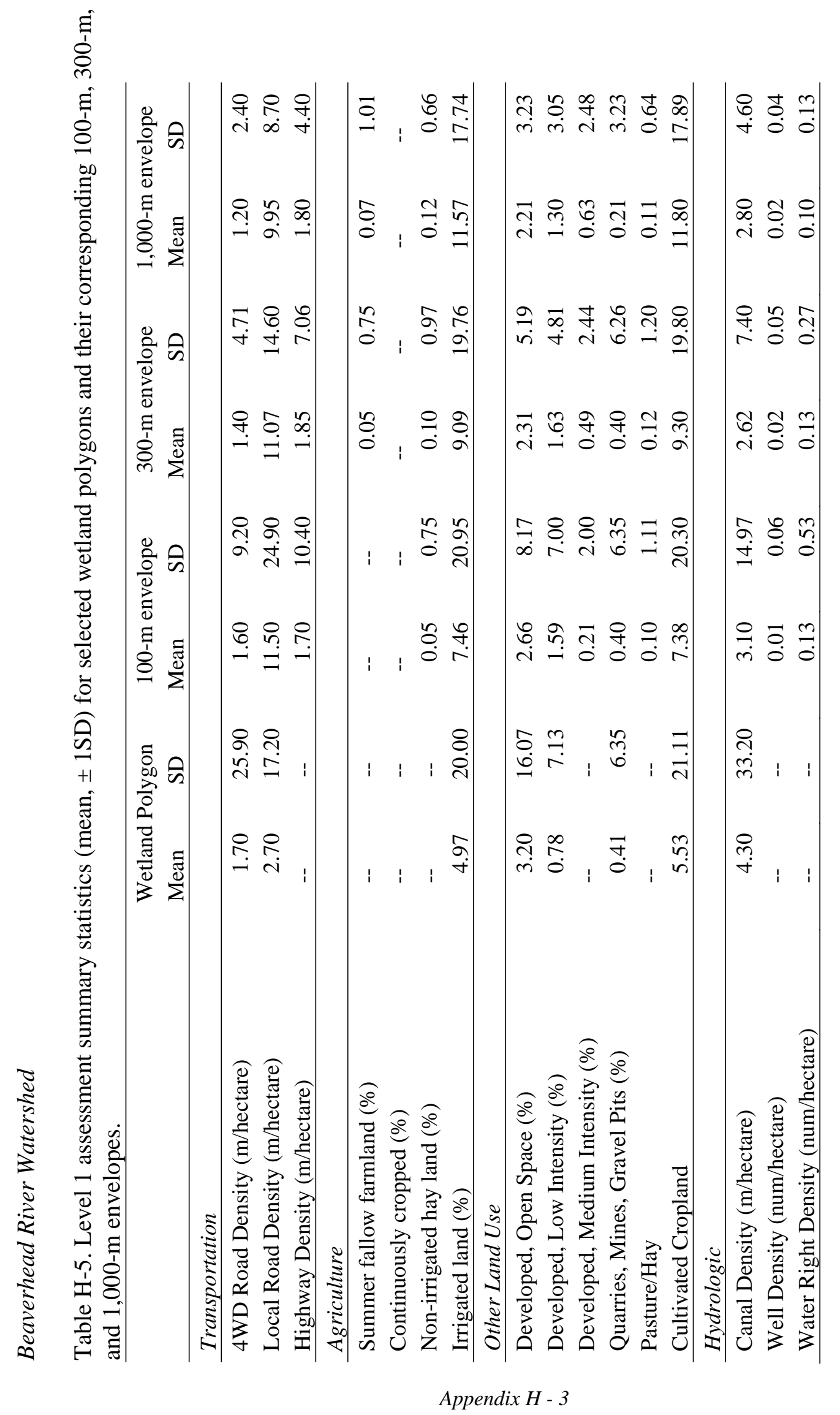




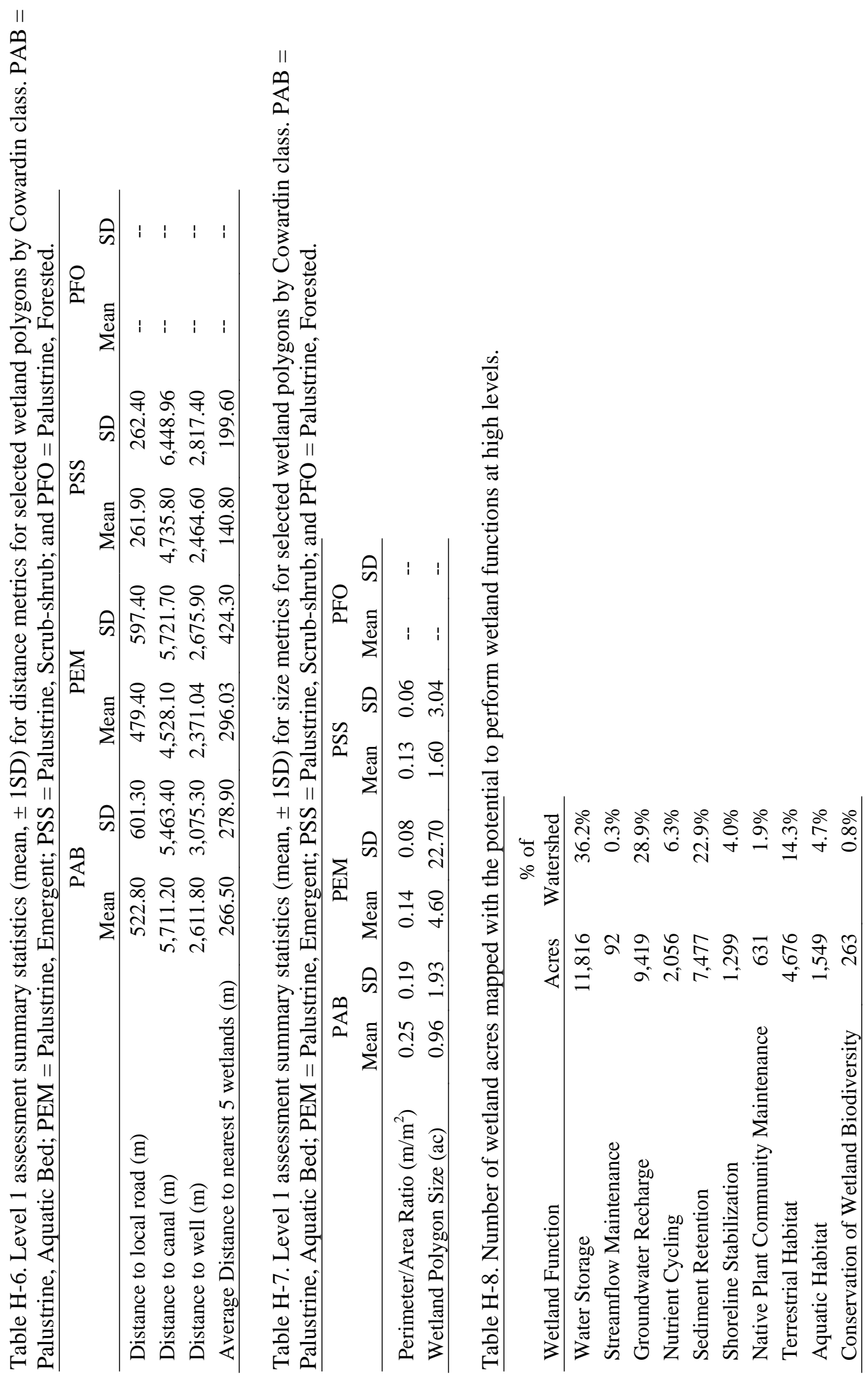

Appendix $H$ - 4 


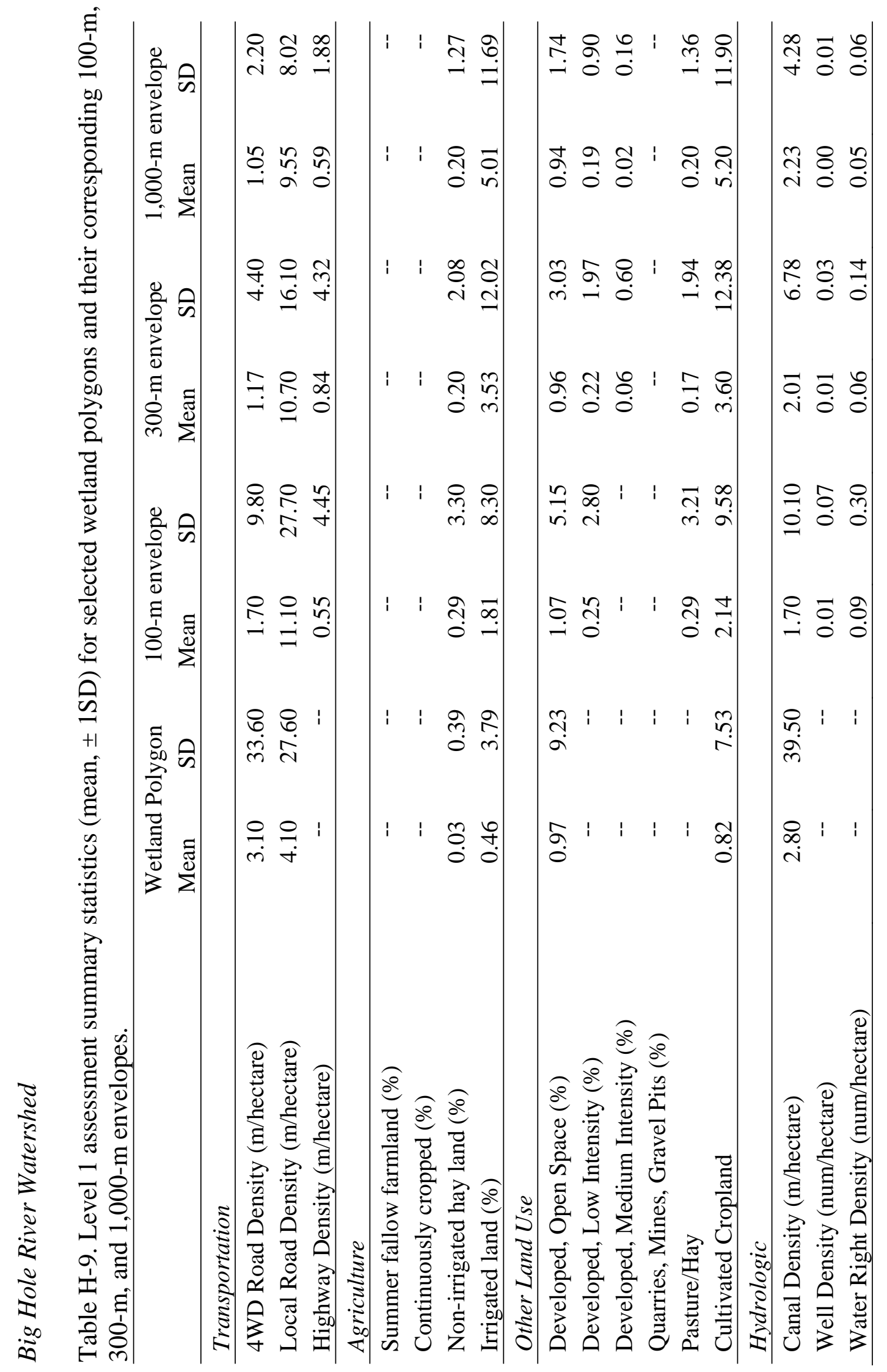

Appendix $\mathrm{H}$ - 5 


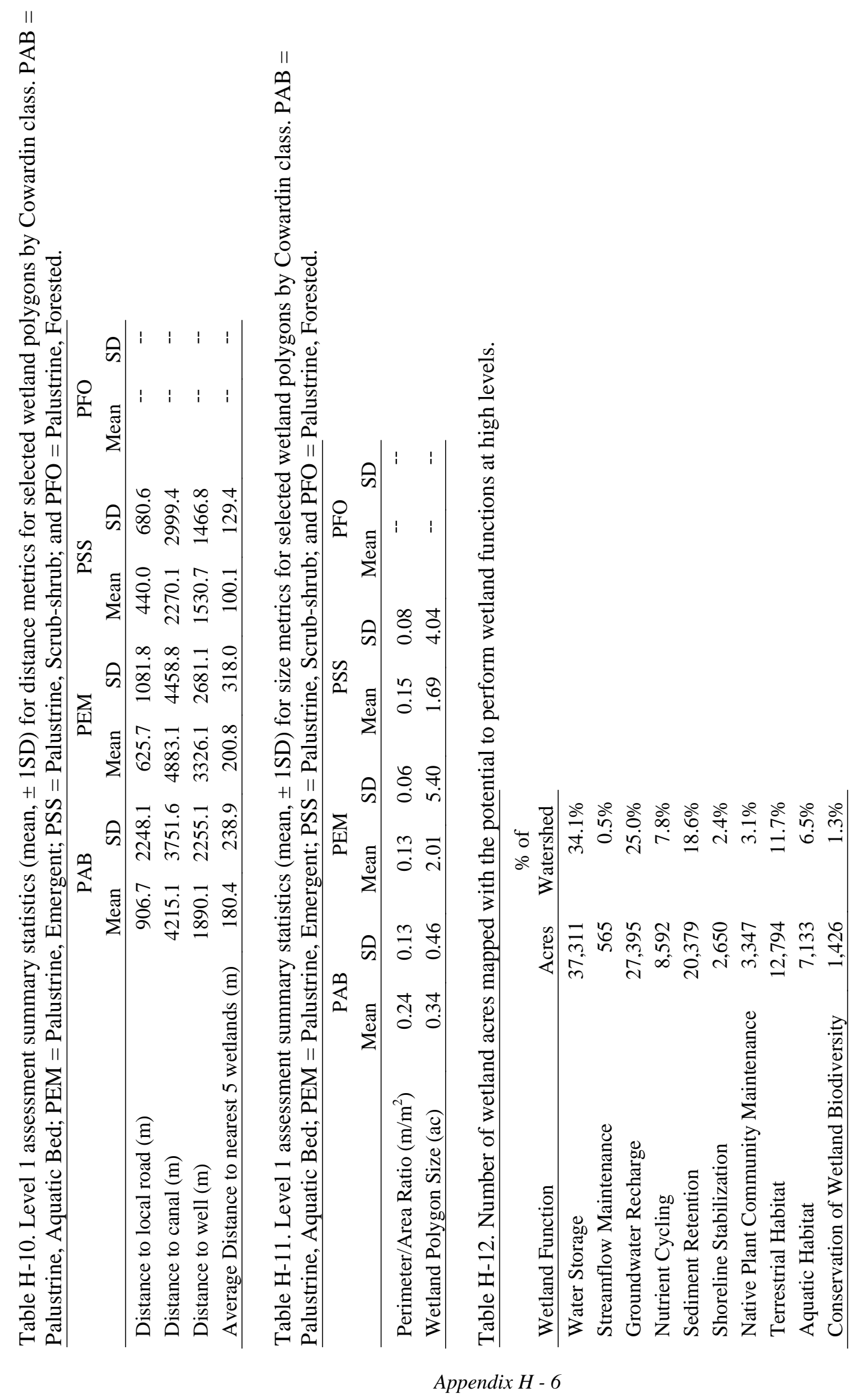




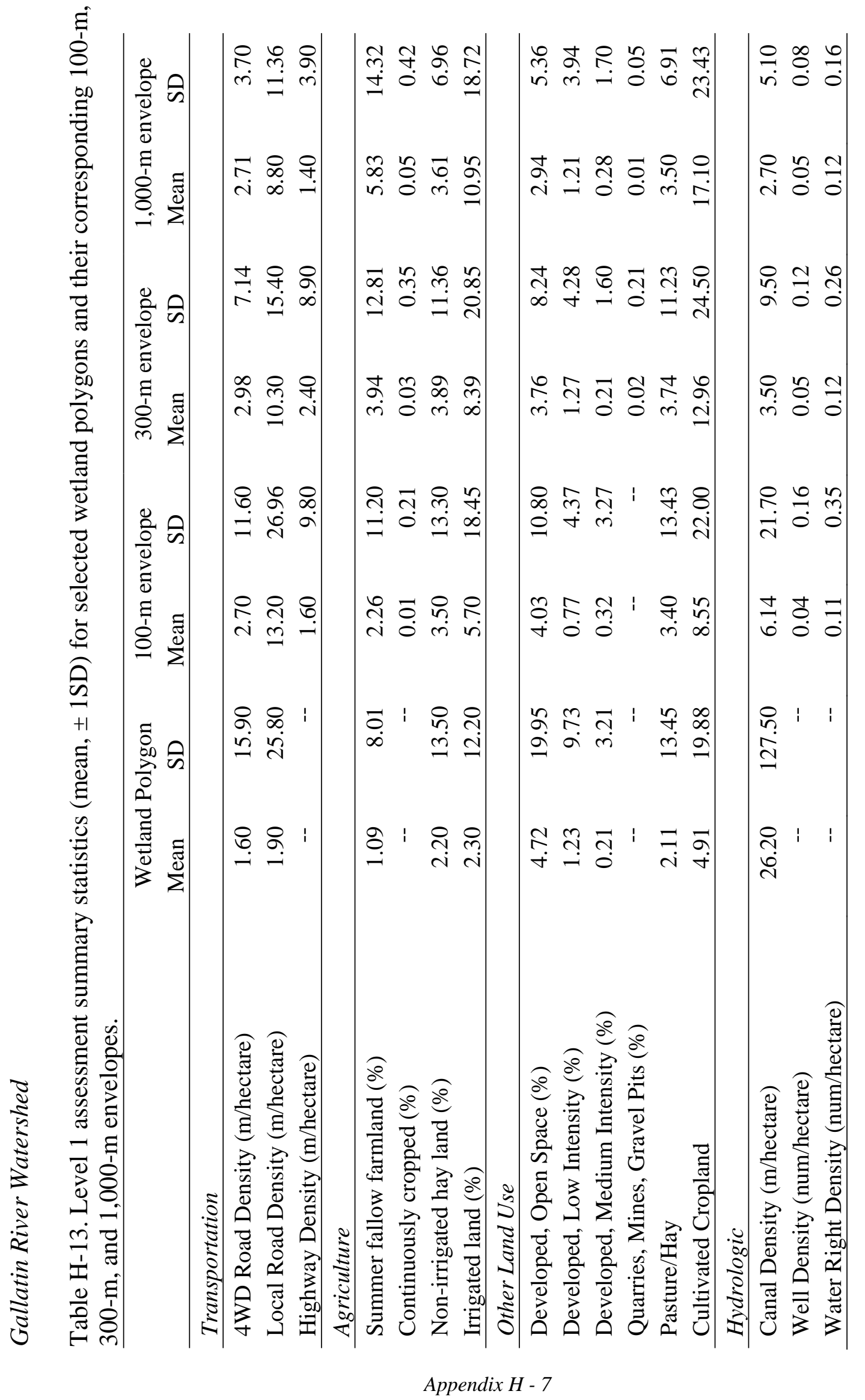




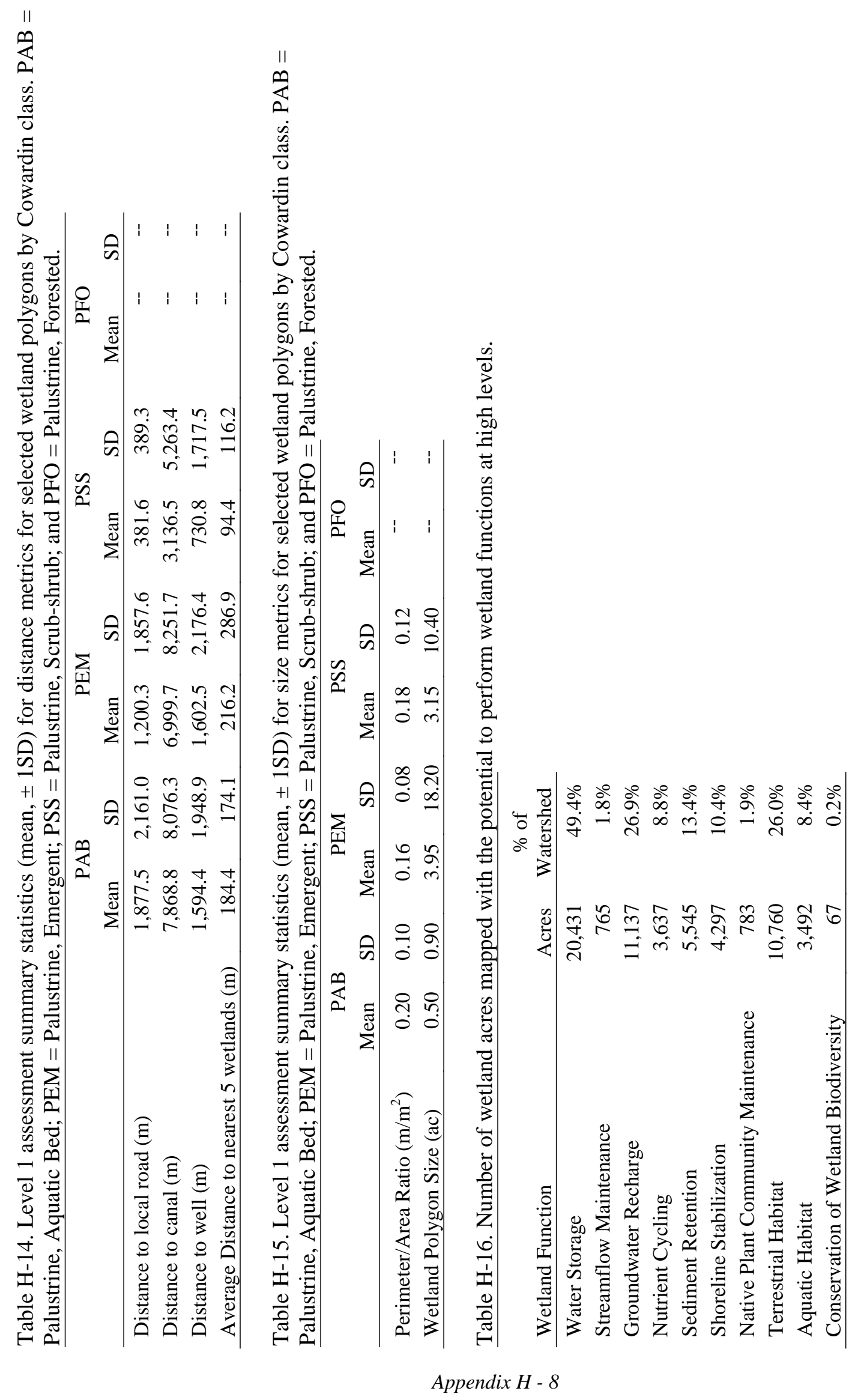




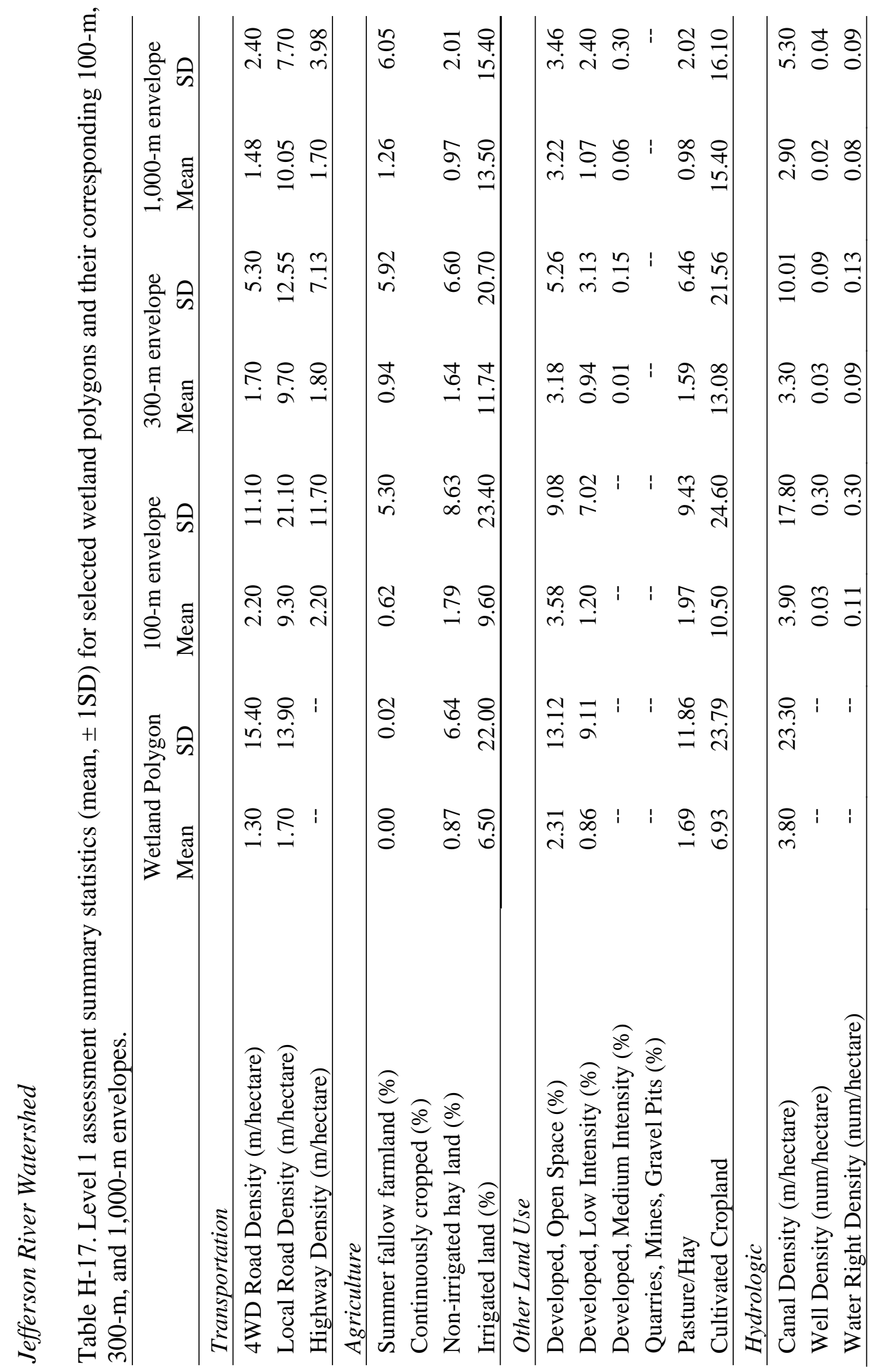

Appendix H - 9 


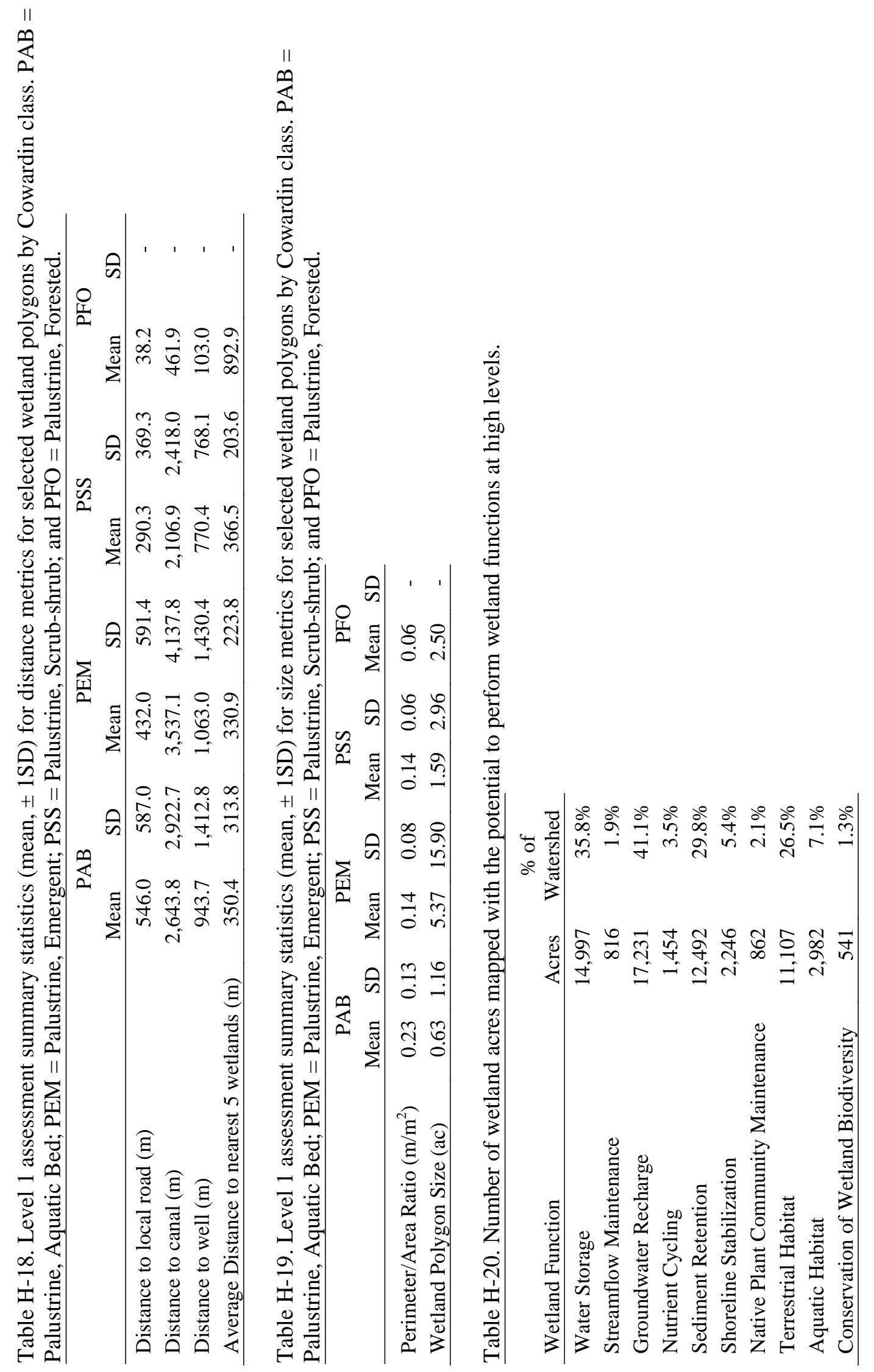

Appendix $\mathrm{H}$ - 10 


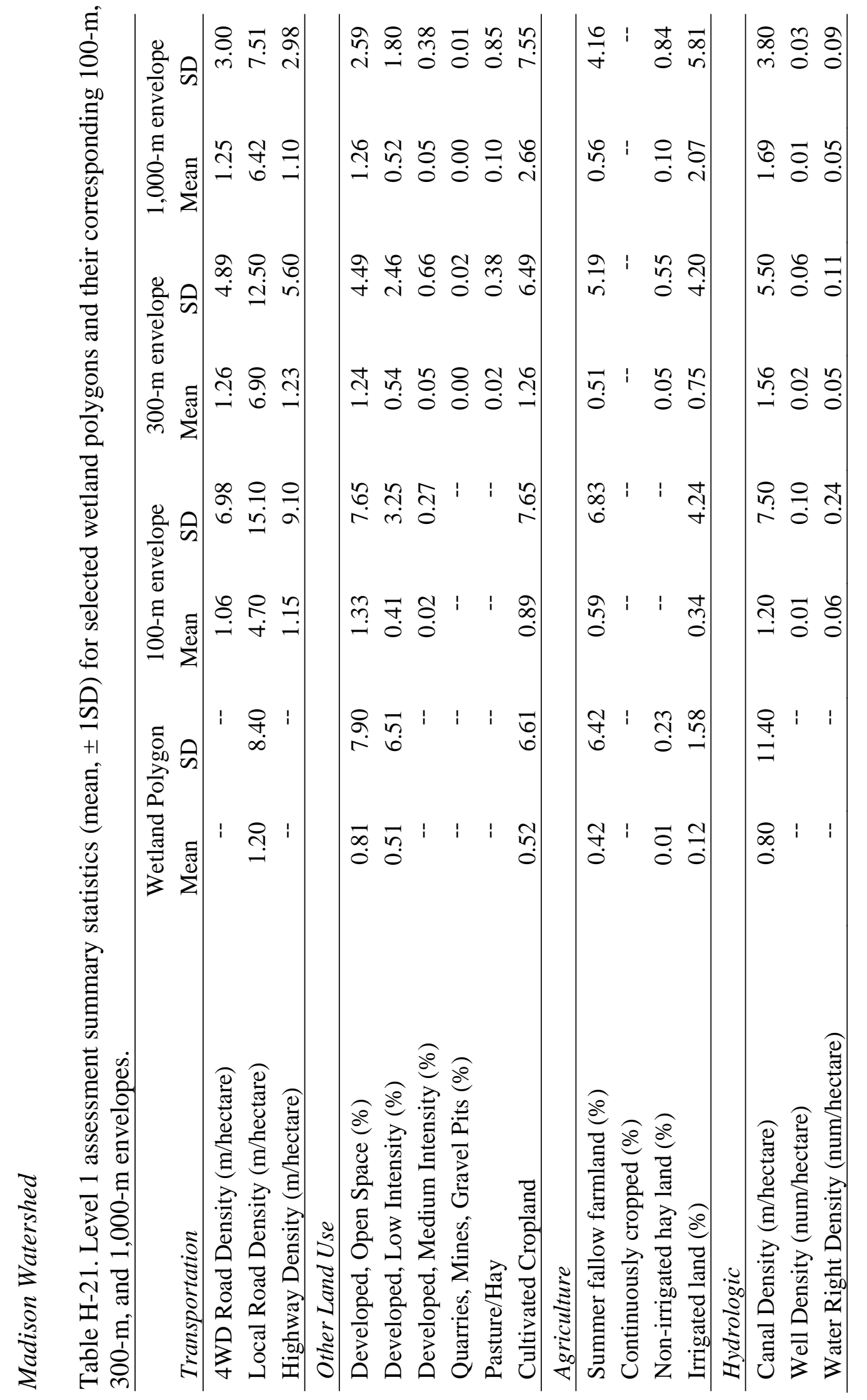

Appendix H - 11 


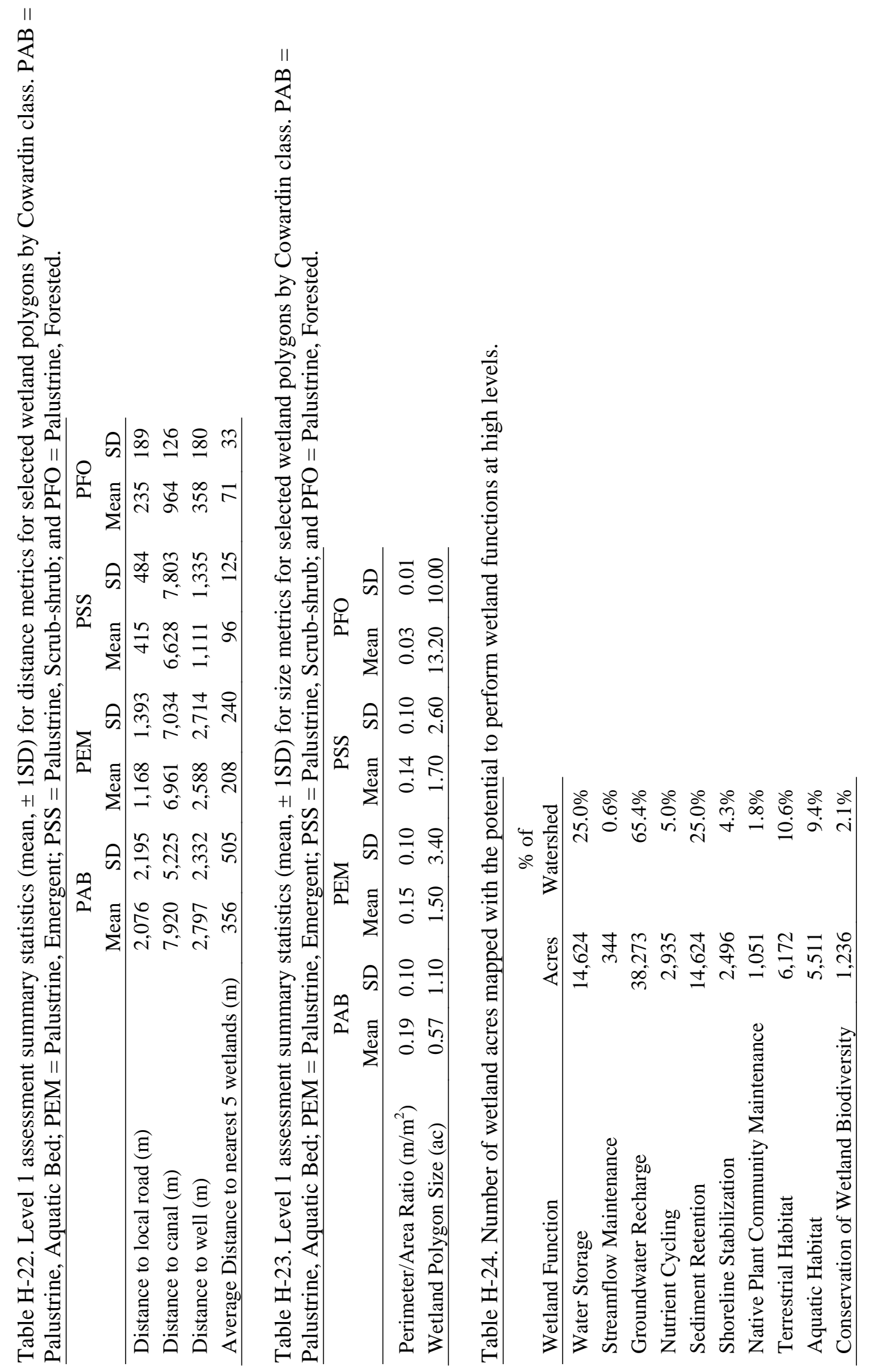

Appendix $\mathrm{H}-12$ 


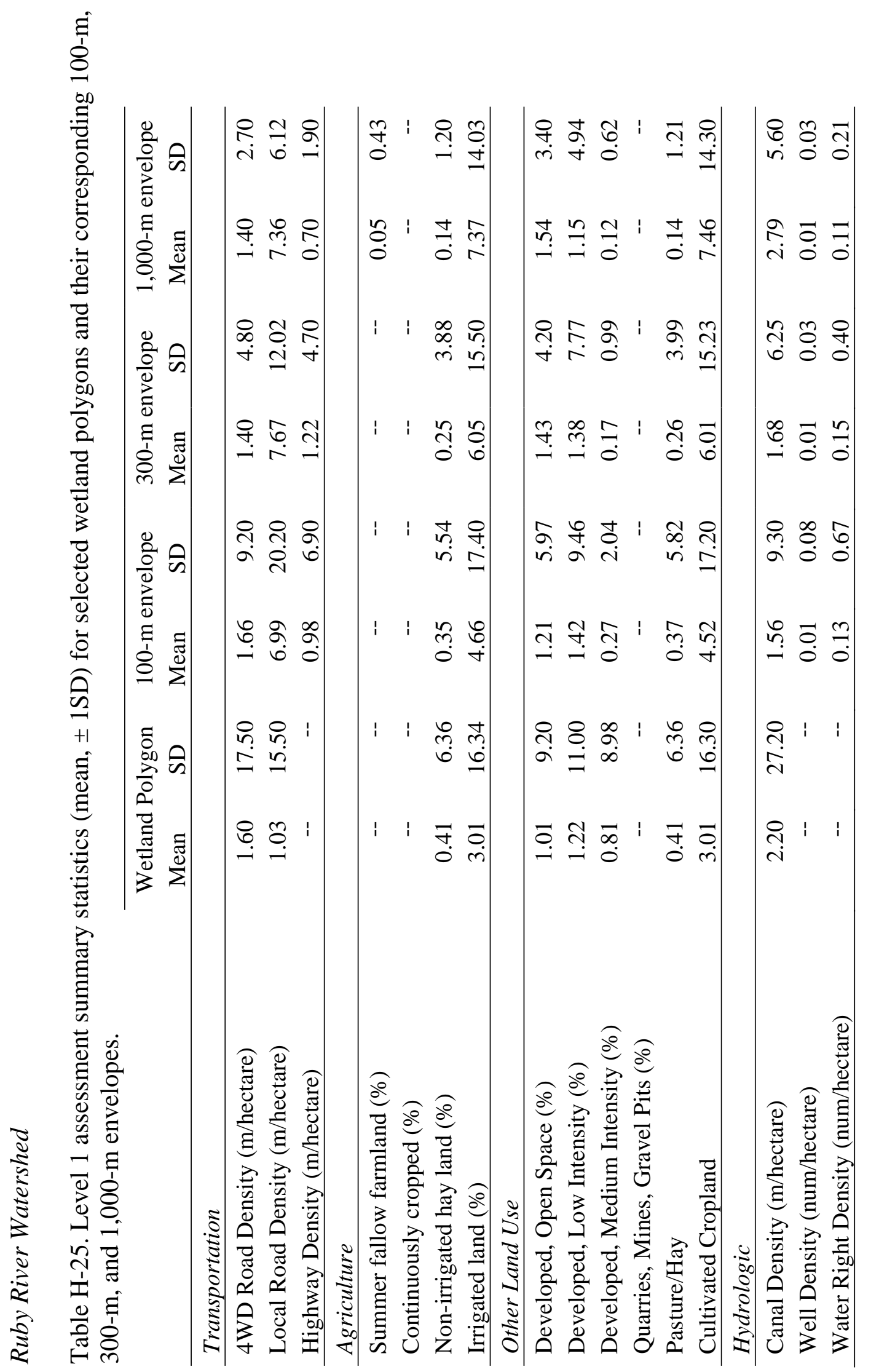

Appendix $H$ - 13 


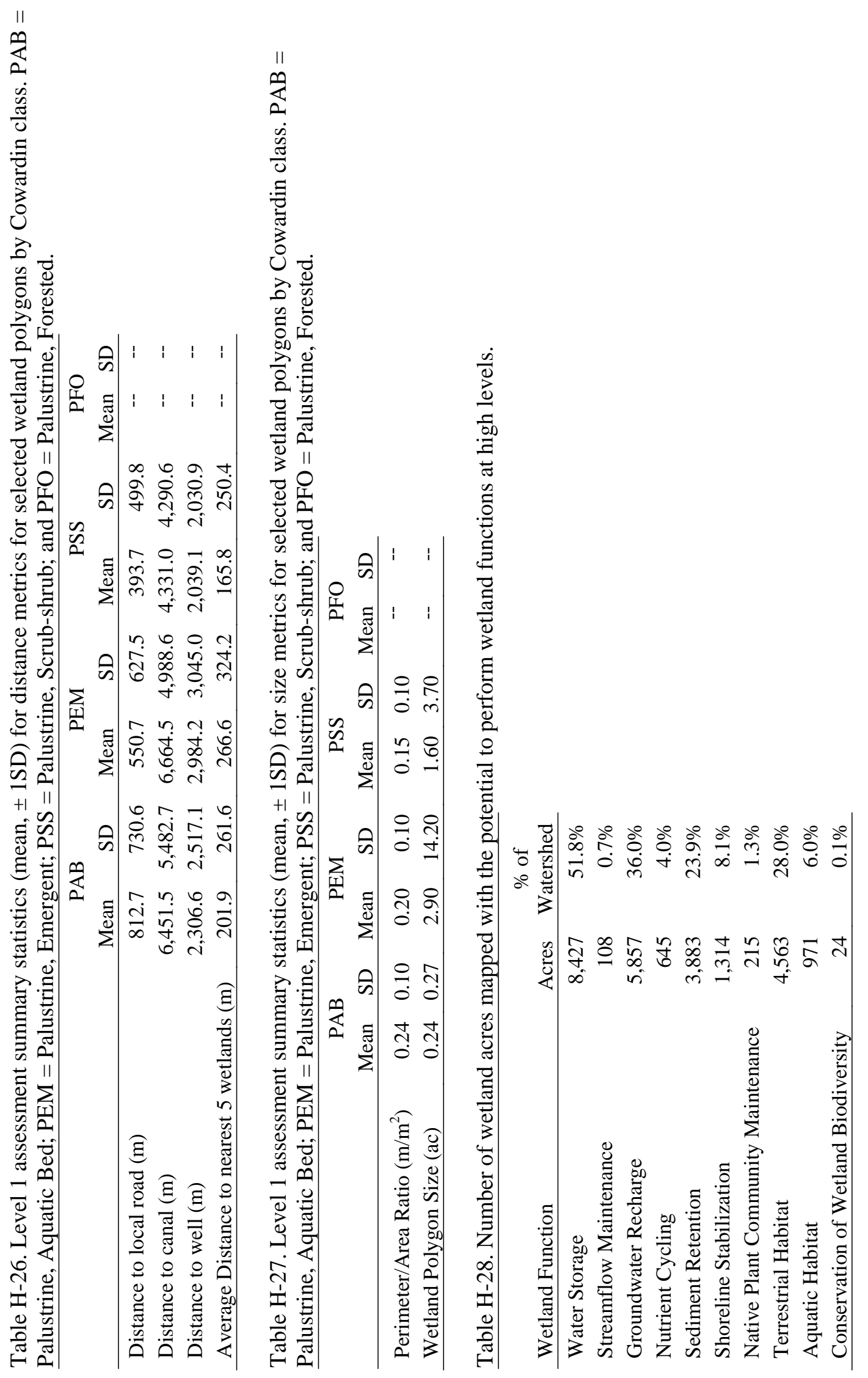

Appendix $\mathrm{H}$ - 14 